Article

\title{
Geochemical Signature and Magnetic Fabric of Capinha Massif (Fundão, Central Portugal): Genesis, Emplacement and Relation with W-Sn Mineralizations
}

\author{
Ana Gonçalves ${ }^{1,2, *(0)}$, Helena Sant' Ovaia ${ }^{1,2}\left(\mathbb{C}\right.$ and Fernando Noronha ${ }^{1,2}{ }^{(1)}$ \\ 1 Departamento de Geociências, Ambiente e Ordenamento de Território, Faculdade de Ciências da \\ Universidade do Porto, Rua do Campo Alegre 687, 4169-007 Porto, Portugal; \\ hsantov@fc.up.pt (H.S.); fmnoronh@fc.up.pt (F.N.) \\ 2 Instituto de Ciências da Terra (ICT), Pólo da Universidade do Porto, Rua do Campo Alegre 687, \\ 4169-007 Porto, Portugal \\ * Correspondence: ana.goncalves@fc.up.pt
}

Received: 18 May 2020; Accepted: 18 June 2020; Published: 20 June 2020

\begin{abstract}
The Fundão-Serra da Estrela-Capinha (FSEC) region is characterized by peraluminous to metaluminous Variscan granites intrusive in a complex and thick metasedimentary sequence. This work seeks to characterize the Capinha granite (CG), understand its spatial and genetic relationship with the host Peroviseu-Seia (PS), Belmonte-Covilhã (BC) and Fáguas granites, and evaluate its metallogenic potential. To achieve these goals, a multidisciplinary approach was undertaken, including field work and identification of the petrography and microstructures, whole rock geochemistry and anisotropy of magnetic susceptibility. Four distinct and independent differentiation trends were identified in the granites, namely, PS, BC, Fráguas and CG. The PS and BC played a role as host rocks for the $\mathrm{W}$ and $\mathrm{Sn}$ mineralizations. The Fráguas granite is anomalous in Sn and spatially related to the Sn-Li mineralizations, while the CG is anomalous in W and spatially related to W-Sn mineralizations. The post-tectonic CG is a peraluminous ilmenite-type whose ascent and emplacement were tectonically controlled. The Capinha magma used the intersection between the $25^{\circ} \mathrm{N}$ and $155^{\circ} \mathrm{N}$ strike-slip crustal scale faults for passive ascent and emplacement during the late-Variscan extensional phases. The magnetic fabric was drawn using an asymmetric tongue-shaped laccolith for CG. CG experienced two brittle deformation stages that marked the maximum compressive rotation from NE-SW to NNW-SSE.
\end{abstract}

Keywords: Variscan granites; differentiation trends; W and Sn mineralizations; post-tectonic Capinha granite; passive emplacement; tongue-shape

\section{Introduction}

The production and emplacement of granitic magmas are well represented in orogenic belts, playing an important role in continental recycling and crustal growth. Granites are good markers of crustal kinematics and allow one to reconstruct the tectonic evolution of orogenic belts, e.g., [1-3].

Granites also act as a source of ore metals and mineralized fluids and/or as a source of heat that generates the large convective fluid circulation responsible for ore deposit formation. Granite's geochemical signatures give important information about (i) the composition of initial granite magmas, (ii) the involved differentiation processes and (iii) the degree of evolution related to the concentration of Sn and W in residual evolved melts and/or the fluids developed during fractional crystallization, e.g., [4-6]. The reconstruction of the evolution of granite intrusions is grounded in 
the interpretation of the internal fabric patterns and microstructures developed during the successive stages of ascent-emplacement and post-emplacement together with the study of the geochemical evolution of granite intrusion. Fabric patterns can be precisely studied using the anisotropy of magnetic susceptibility (AMS) technique $[7,8]$. The use of AMS studies is crucial for granitic rocks since, at a macroscopic scale, the preferred orientation of iron-bearing minerals is weakly marked or absent [8-10]. Thus, granite's kinematic may be inferred by mapping its internal magnetic fabric and anisotropy magnitudes, which can reflect the magmatic strain pattern of the magma [11-15].

The magnetic susceptibility $\left(K_{\mathrm{m}}\right)$ obtained from AMS measurements has an important role in the distinction between "magnetite-type" (ferromagnetic behavior, [10]) and "ilmenite-type" (paramagnetic behavior, [10,12]) granites [16]. Several studies have been done to constrain the limits between paraand ferromagnetic behaviors. The authors in [17] suggested that paramagnetic behavior is below $1000 \mu$ S.I., the authors in [18] suggested that the limit is near $300 \mu$ S.I., the authors in [19] proposed a boundary close to $200 \mu$ S.I., and the researchers in [20] found paramagnetic behaviors in leucogranites bellow $100 \mu$ S.I. This range of values is directly related to the contents of ilmenite and magnetite in the accessory fraction of the granite composition. Thus, the "magnetite-type" contains about $0.1 \mathrm{vol} \%-2.0 \mathrm{vol} \%$ of magnetite, and the "ilmenite-type" presents only ilmenite at less than $0.1 \mathrm{vol} \%$ [17]. According to the work in [17] and [21], "magnetite-type" magma may be generated at low depths (lower crust to upper mantle), where no carbonaceous material exists. Magnetite- and ilmenite-type granite classification is important to understand the redox conditions in the magma, as well as to infer what kind of mineral occurrence is associated with each type of granite [17].

In the Iberian Variscan Belt, the processes responsible for the genesis of compositionally distinct granitic magmas involves the partial melting of distinct rock sources, hybridization, and/or the mixing of contrasting magmas, fractional crystallization, crustal contamination and assimilation-fractional crystallization [22-32].

The NW area of the Iberian Peninsula is characterized by the existence of a W-Sn metallogenic province associated with granite intrusions [33-35]. The W-Sn deposits occur in greisens and/or quartz veins related to late-orogenic biotite-rich granites and biotite-muscovite granites [36-38].

The Fundão-Serra da Estrela-Capinha region is extremely important from the perspective of W-Sn ore deposits, as it contains not only the largest underground W-Sn mine in the Iberian Peninsula (the Panasqueira mine), but also several old mines and small occurrences of W-Sn that were intensively explored in the first half of the last century.

In this article, we study a small-scale intrusion whose emplacement was structurally controlled and spatially associated with W-Sn mineralizations - the Capinha granite located in the Fundão-Serra da Estrela-Capinha region. The fieldwork, petrography, microstructures, whole rock geochemistry, and AMS data of the Capinha granite used to achieve these main goals are reported in this study. The Capinha granite offers a good opportunity to better understand the structural constraints of the emplacement of post-tectonic Variscan granite under extensional settings, determine its spatial and genetic relationship with the surrounding $r$ its metallogenic potential.

\section{Regional Geology}

The Iberian Variscan Belt (IVB) (or Iberian Massif) is a well-exposed section of continental crust resulting from a collision of the Gondwana and Laurussia supercontinents. This continental collision halted the closure of the Rheic Ocean during the Late Devonian to Middle Carboniferous, followed by a post-thickening extension from the Middle Carboniferous to the Permian [39-43].

Three main regional ductile deformation phases have been described $\left(\mathrm{D}_{1}, \mathrm{D}_{2}\right.$ and $\left.\mathrm{D}_{3}\right)[40,41,44-46]$ in NW Spain and N and Central Portugal, corresponding to the Galiza-Trás-os-Montes Zone (GTMZ) and the Central Iberian Zone (CIZ) $[47,48] . \mathrm{D}_{1}$ and $\mathrm{D}_{2}$ were responsible for the greatest amount Variscan crustal growth. $\mathrm{D}_{3}$ is correlated with the post-thickening and extension that marked the end of continental collisions $[48,49] . \mathrm{D}_{3}$ produced vertical folds with a sub-horizontal axis and subvertical dextral and sinistral strike-slip shear zones [50], which were responsible for the emplacement of 
a large volume of orogenic granites. The ages of $\mathrm{D}_{1}, \mathrm{D}_{2}$ and $\mathrm{D}_{3}$ are $360-337 \mathrm{Ma}, 337-316 \mathrm{Ma}$ and 315-310 Ma, respectively [32,51]. The authors in [52], based on the Tourmaline ${ }^{40} \mathrm{Ar} /{ }^{39} \mathrm{Ar}$ chronology of tourmaline-rich rocks, dated the main Variscan deformation phases as $\mathrm{D}_{1}-370 \pm 5 \mathrm{Ma}$ and $\mathrm{D}_{2}-342 \pm 5 \mathrm{Ma}$, and obtained an age of ca. $296 \mathrm{Ma}$ for tourmalines in the youngest leucogranites. The emplacement of lamprophyre dykes at ca. $265 \mathrm{Ma}$ [53] reveals an extension-related crustal melting setting typical of the late Variscan stages.

In the allochthonous domain of IVB (i.e., in the GTMZ), three deformational phases are evidenced, where $\mathrm{D}_{2}$ is associated with thrusts. In the allochthonous domain (i.e., in the CIZ), only the $\mathrm{D}_{1}$ and $D_{3}$ deformation phases are represented [43]. $D_{3}$ is followed by brittle deformation phases post- $D_{3}$ (310-270 Ma, [54]), which are responsible for a set of conjugate strike-slip faults (NNW-SSE, NNE-SSW and ENE-WSW) related to the maximum N-S shortening [46,54-57].

Based on fieldwork observations and geochronological data, the granites situated in the CIZ and GTMZ were divided into six main groups according to their age of emplacement relative to $\mathrm{D}_{3}$ [58-61]: pre- $\mathrm{D}_{3}$ (331-321 Ma); syn- $\mathrm{D}_{3}$ (321-312 Ma); late- $\mathrm{D}_{3}$ (312-305 Ma), late- to post-D 3 (ca. $\left.300 \mathrm{Ma}\right)$; and post- $\mathrm{D}_{3}(<299 \mathrm{Ma})$, where granites younger than $310 \mathrm{Ma}$ are considered post-collisional (Figure 1).
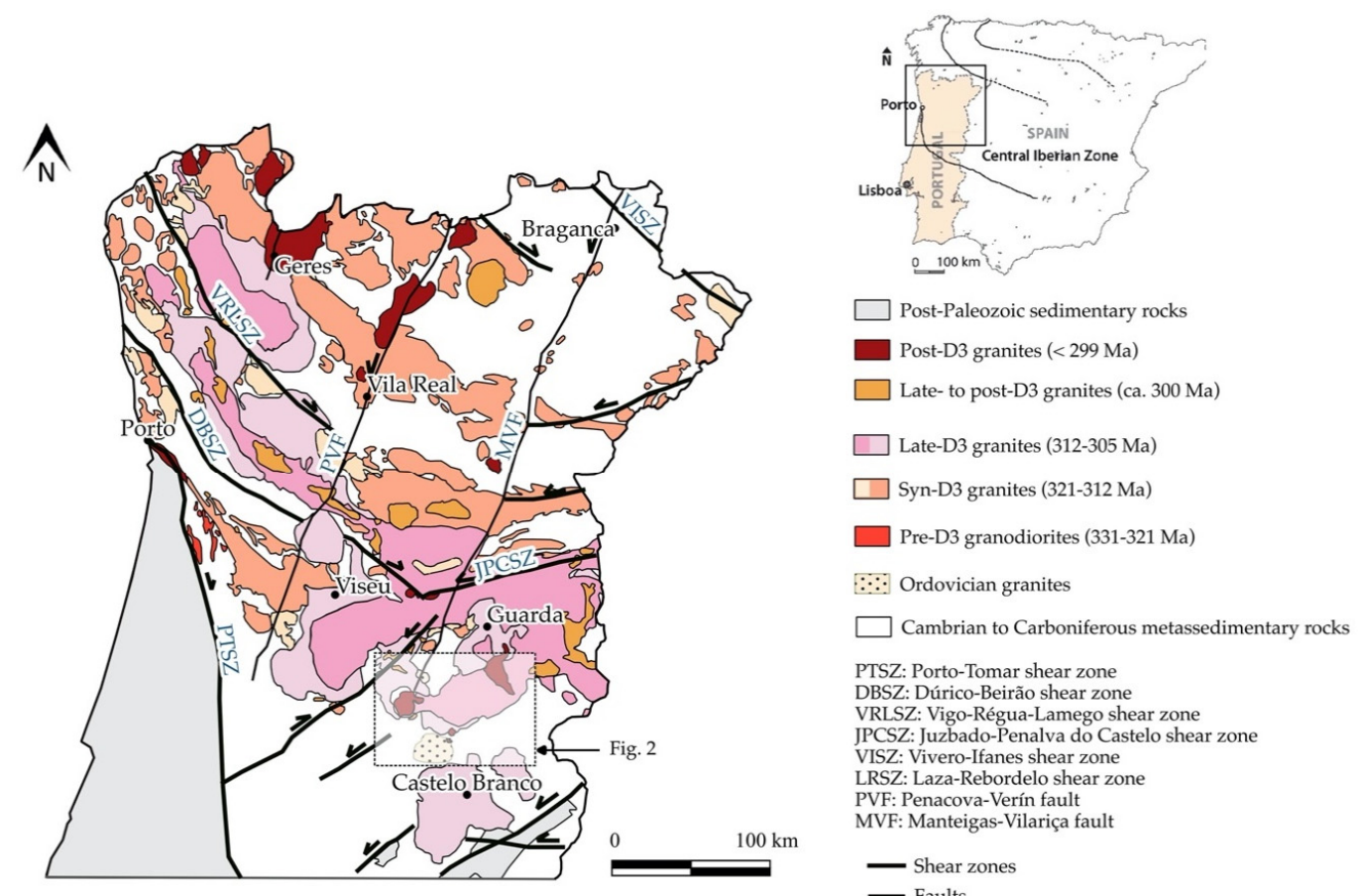

PTSZ: Porto-Tomar shear zone

DBSZ: Dúrico-Beirão shear zone

VRLSZ: Vigo-Régua-Lamego shear zone

JPCSZ: Juzbado-Penalva do Castelo shear zone

VISZ: Vivero-Ifanes shear zone
LRSZ: Laza-Rebordelo shear zone

PVF: Penacova-Verín fault

MVF: Manteigas-Vilariça fault

- Shear zones

- Faults

Figure 1. Spatial distribution of the Variscan granites and the major structures in central and northern Portugal (adapted from [58]).

\section{Fundão-Serra da Estrela-Capinha Region}

\subsection{Geology and Field Relationships}

The Fundão-Serra da Estrela-Capinha region (FSEC) is located in the CIZ, Central Portugal. This region is characterized by the occurrence of several outcrops belonging to a set of different intrusive granitic massifs in metasedimentary sequences from the Beiras group (the "Schist Greywacke Complex" (SGC), which is Neoproterozoic in age) [62-65]. The SGC sequences displays dominant NW-SE trending foliation $\left(\mathrm{S}_{1}\right)$ with vertical or subvertical dips $\left(80^{\circ}\right.$ to $\left.85^{\circ} \mathrm{SW}\right)$. The study area is cut by an important NNE-SSW regional fault, the Vilariça-Manteigas fault (VMF).

The intrusive granites from FSEC correspond to four different groups: Ordovician granites, late- $\mathrm{D}_{3}$, late- to post- $\mathrm{D}_{3}$ and post- $\mathrm{D}_{3}$ granites (Figure 2). 
- The Ordovician group is represented by Manteigas granite (482 $\pm 6 \mathrm{Ma}$, [27]), which is a biotite-rich, coarse-grained, porphyritic granodiorite with clear foliation with tonalites and monzonitic granites that constitute the composite and zoned pluton of Fundão [66-68]. Recent geochronological data yielded an Ordovician age (478.1 $\pm 0.5 \mathrm{Ma}$ and $478.4 \pm 0.5 \mathrm{Ma}$, respectively, for tonalite and monzogranite) for the Fundão pluton [69].

- The late- $\mathrm{D}_{3}$ group is represented by Peroviseu (on the east side of VMF) and Seia (on the west side of VMF), which comprise the Peroviseu-Seia granite (PS) and Castelo Branco granite (CB). The PS is biotite-rich, coarse- to very coarse-grained porphyritic granite. The distribution of $\mathrm{K}$ feldspar is generally random, although an E-W magma flow, marked by slightly oriented $\mathrm{K}$ feldspar, was recognized. These granites occasionally have some enclaves with granodioritic to tonalitic composition. $\mathrm{CB}$ is a complex zoned pluton; from the core to the periphery, it is composed of muscovite-biotite granite, biotite \pm muscovite porphyritic granodiorite and muscovite-biotite granite.

- The late- to post- $\mathrm{D}_{3}$ group is represented by biotite-rich monzonitic granites (Belmonte-Covilhã granite). Belmonte-Covilhã (BC) is a biotite-rich, coarse-grained, porphyritic monzogranite and displays well-defined deformation patterns with oriented $\mathrm{K}$ feldspar megacrysts. The contacts between the BC and PS are, generally, gradual. On the other hand, the contact between the BC and the metasediments have an NE-SW trend and are characterized by the occurrence of mottled schists and hornfels due to the thermal metamorphism related to the BC emplacement.

- The post- $\mathrm{D}_{3}$ granite group is composed of two-mica leucogranites-Capinha (CG), Estrela, Fráguas, Atalaia and non-outcropping Panasqueira granite.

CG is a muscovite > biotite, medium-grained, incipient porphyritic granite. CG occurs as a small circular circumscribed body exposed over an area of about $7 \mathrm{~km}^{2}$, intruding into the low-grade metamorphic Schist-Greywackes of SGC, $\sim 15 \mathrm{~km}$ to the north-east of Fundão village (Figure 2). CG intrudes the contact between the PS granite and the SGC and cuts the foliations of the SGC. In the whole extension, the contacts with steeply dipping metasediments are sharp and nearly vertical, with no apparent structural deformations, suggesting that the granite was not forcibly emplaced. The textural characteristics of CG are homogeneous in the whole area, without any magmatic flow foliation or superimposed deformation.

The two-mica leucogranite group is characterized by irregular bodies intruding in the BC, Fráguas (on the east side of VMF), Estrela (on the west side of VMF) and Atalaia (on the east side of VMF). The Estrela muscovite-rich granite is located at the highest point of the Portugal mainland ( 2000 $\mathrm{m}$ high) in the Serra da Estrela mountain. Fráguas granite is irregular and elongated NW-SE, suggesting structural control of its emplacement. The dominant facies are composed by two-mica, medium-grained granites, although coarse-grained facies also occur. Fráguas granite exhibits a gradual petrographic zonation corresponding to the biotite-rich facies in the central part and muscovite-rich facies in the peripheries [70]. The Estrela and Fráguas granites occupy the dome areas of the BC biotite-rich porphyritic granite. Atalaia granite is a tourmaline-muscovite, medium-grained, porphyritic granite located in the north-eastern side of the Fundão pluton $[66,68]$.

In the Panasqueira area, where no granites outcrop, underground mining crosses a greisen cupula. Several authors [71-79] suggested that this greisen cupola is connected to a non-outcropping granite dome. Subsequent research surveys intercepted a two-mica fresh granite (with muscovite that is dominantly secondary in origin), which was dated in [80] to ca. $289 \pm 4 \mathrm{Ma}$ (whole-rock $\mathrm{Rb}-\mathrm{Sr}$ ) with a high ${ }^{87} \mathrm{Sr} /{ }^{86} \mathrm{Sr}_{\mathrm{i}}$ ratio of 0.713 . 


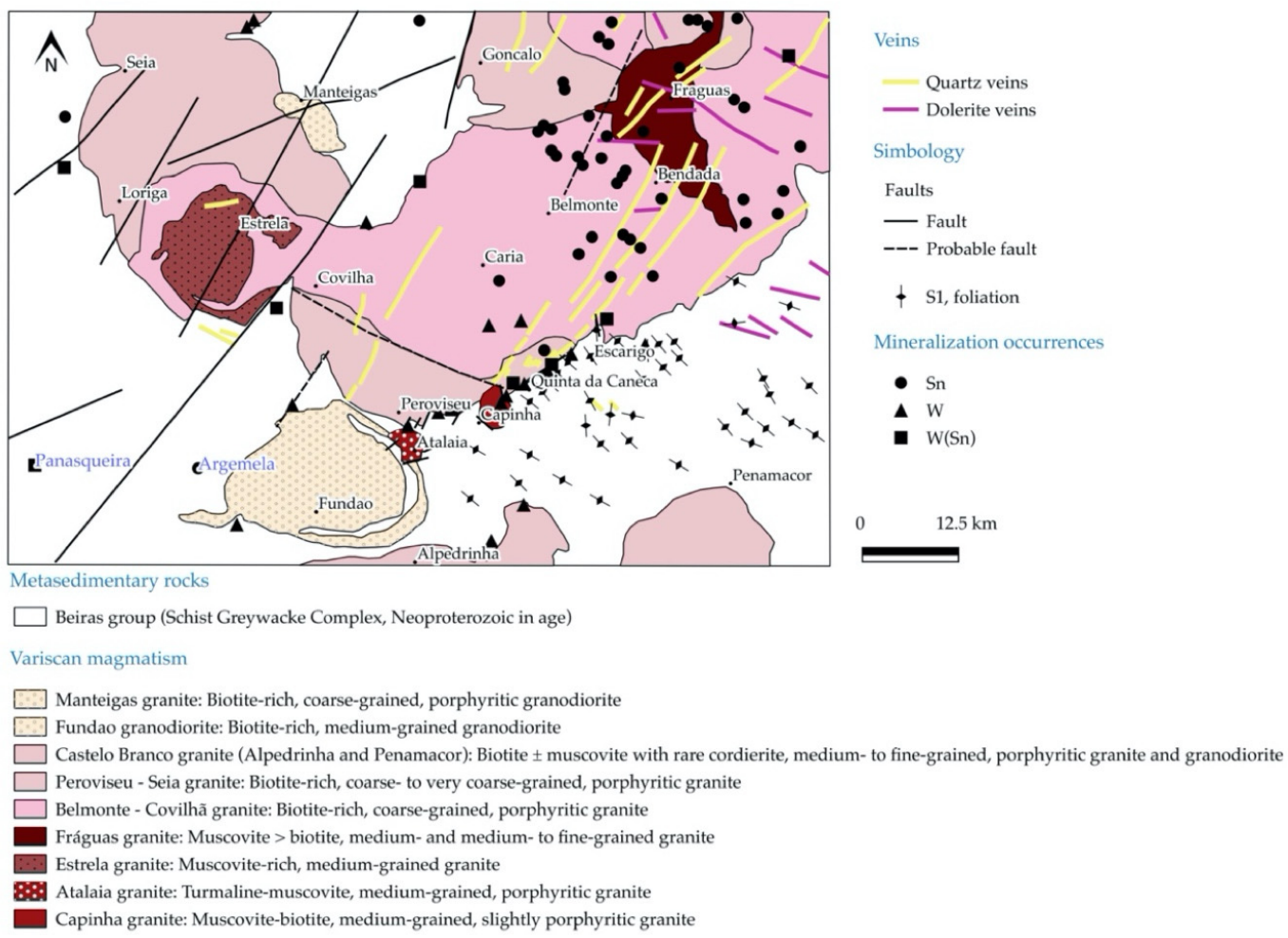

Figure 2. Simplified Fundão-Serra da Estrela-Capinha region geological map and Sn, W and W(Sn) occurrences associated with Variscan granites [58,67,82].

In Table 1 is described the general features of the outcropping lithologies in the Fundão-Serra da Estrela-Capinha region. 
Table 1. General features of the outcropping lithologies in the Fundão-Serra da Estrela-Capinha region [81,82]. n.d.- not determined.

\begin{tabular}{|c|c|c|c|}
\hline Lithology & Dating & Description & Mineralogy \\
\hline \multicolumn{4}{|c|}{ Schist-Greywacke Complex (SGC) and derivate metamorphic series } \\
\hline Schists and greywackes & Neoproterozoic & $\begin{array}{c}\text { Sequences characterized by the interlayering of } \\
\text { fine-to-medium-grained, gray to greenish color } \\
\text { greywackes and fine- to medium-grained shining } \\
\text { phyllites. }\end{array}$ & $\begin{array}{l}\text { The main mineralogy of greywackes is quartz, } \mathrm{K} \text { feldspar, } \\
\text { chlorite and sericite; this biotite can occur in zones where } \\
\text { the metamorphic effect is more intense. The schist is mostly } \\
\text { composed of quartz, biotite and muscovite; } \mathrm{K} \text { feldspar, } \\
\text { tourmaline and graphite are present as accessories in } \\
\text { mineralogy. }\end{array}$ \\
\hline \multicolumn{4}{|c|}{ Ordovician granites } \\
\hline Manteigas granite & $482 \pm 6 \mathrm{Ma}[27]$ & $\begin{array}{l}\text { Biotite-rich, coarse-grained, porphyritic } \\
\text { granodiorite with clear foliation. }\end{array}$ & $\begin{array}{l}\text { Quartz, microcline, plagioclase, biotite, chlorite, sphene, } \\
\text { apatite, zircon, rutile, magnetite and ilmenite. }\end{array}$ \\
\hline Fundão granite & $\begin{array}{l}478.1 \pm 0.5 \mathrm{Ma} \text { and } 478.4 \pm 0.5 \mathrm{Ma} \text { for } \\
\text { tonalite and monzogranite, } \\
\text { respectively [69] }\end{array}$ & $\begin{array}{l}\text { The Fundão intrusive complex consists of } \\
\text { granodioritic zoned pluton. The central part } \\
\text { features granodiorites and an outermost zone of } \\
\text { biotite granite. }\end{array}$ & $\begin{array}{l}\text { Quartz, } \mathrm{K} \text { feldspar (microcline), plagioclase } \\
\text { (oligoclase-andesine), biotite, muscovite, apatite, topaz, } \\
\text { allanite, epidote, sphene, rutile, ilmenite and pyrite. }\end{array}$ \\
\hline \multicolumn{4}{|c|}{ Late- $\mathrm{D}_{3}$ granites } \\
\hline Peroviseu-Seia granite (PS) & $304.1 \pm 3.9 \mathrm{Ma}[83]$ & $\begin{array}{l}\text { Biotite-rich, coarse- to very coarse-grained } \\
\text { porphyritic granite. }\end{array}$ & $\begin{array}{l}\text { Quartz, microperthite microcline, plagioclase, biotite, } \\
\text { chlorite, muscovite, zircon, apatite, monazite, ilmenite, } \\
\text { rutile and rare cordierite. }\end{array}$ \\
\hline $\begin{array}{c}\text { Castelo Branco granite (CB) (Alpedrinha } \\
\text { and Penamacor) }\end{array}$ & $310 \pm 1 \mathrm{Ma}[84]$ & $\begin{array}{c}\text { CB is a complex zoned pluton composed by } \\
\text { muscovite-biotite granite in the core, which is } \\
\text { surrounded by biotite } \pm \text { muscovite porphyritic } \\
\text { granodiorites and muscovite-biotite granite in the } \\
\text { peripheries. }\end{array}$ & $\begin{array}{l}\text { Quartz, microperthitic microcline, plagioclase, biotite, some } \\
\text { chlorite, muscovite, tourmaline, monazite, apatite, zircon, } \\
\text { ilmenite and rutile. The CB also contains magmatic } \\
\text { andalusite, sillimanite and cordierite. }\end{array}$ \\
\hline \multicolumn{4}{|c|}{ Late- to post- $\mathrm{D}_{3}$ granites } \\
\hline Belmonte-Covilhã granite (BC) & $300 \pm 1 \mathrm{Ma}[28]$ & Biotite-rich, coarse-grained, porphyritic granite. & $\begin{array}{l}\text { Quartz, K feldspar, plagioclase, biotite } \pm \text { muscovite } \pm \\
\text { chlorite, zircon, rutile, sphene, tourmaline, ilmenite, fluorite } \\
\text { and opaques. Rare andalusite can occur. }\end{array}$ \\
\hline \multicolumn{4}{|c|}{ Post- $\mathrm{D}_{3}$ granites } \\
\hline Fráguas & $299 \pm 3 \mathrm{Ma}[28]$ & $\begin{array}{c}\text { Muscovite }>\text { biotite, medium- and medium- to } \\
\text { fine-grained granites. }\end{array}$ & \multirow{4}{*}{$\begin{array}{l}\text { Quartz, K feldspar (microcline, albite, albite-oligoclase and } \\
\text { microperthite), fresh biotite, zircon. The K feldspars are } \\
\text { strongly altered to sericite and kaolin. } \\
\text { Quartz, K feldspar, albite, muscovite or bleached biotite } \\
\text { and tourmaline. } \\
\text { Quartz, K feldspar (microcline), albite muscovite and } \\
\text { tourmaline. } \\
\text { Quartz, K feldspar (microcline >> orthoclase), plagioclase } \\
\text { (albite-oligoclase), micas (muscovite > biotite } \pm \text { chlorite), } \\
\text { apatite, zircon, rutile and metallic phases. The plagioclase } \\
\text { is strongly altered to sericite and kaolin. }\end{array}$} \\
\hline Atalaia granite & n.d. & $\begin{array}{l}\text { Tourmaline muscovite, medium-grained, } \\
\text { porphyritic granite. }\end{array}$ & \\
\hline Estrela granite & n.d. & Muscovite-rich, medium-grained granite. & \\
\hline Capinha granite & n.d. & $\begin{array}{c}\text { Muscovite }>\text { biotite, medium-grained, incipient } \\
\text { porphyritic granite. }\end{array}$ & \\
\hline
\end{tabular}




\subsection{Regional Brittle Deformation}

The Fundão area includes four main subvertical fracturing systems $\left(60^{\circ} \mathrm{N}-70^{\circ} \mathrm{E}, 100^{\circ} \mathrm{N}-110^{\circ} \mathrm{E}\right.$, $30^{\circ} \mathrm{N}-40^{\circ} \mathrm{E}$ and $150^{\circ} \mathrm{N}-160^{\circ} \mathrm{E}$ ) and also sub-horizontal joints (Figure 2). These fracturing systems affect the whole area with distinct intensities, conditioning different geological processes, as follows:

1. The $60^{\circ} \mathrm{N}-70^{\circ} \mathrm{E}$ fracturing system is well marked in the contact between PS and BC biotite-rich porphyritic granites and metasedimentary rocks.

2. The $100^{\circ} \mathrm{N}-110^{\circ} \mathrm{E}$ fractures control the emplacement of the PS granites recorded in the $\mathrm{E}-\mathrm{W}$ magmatic flow by the $\mathrm{K}$ feldspar orientation and its reactivation during the late-Variscan stages, which promoted the emplacement of Sn aplite-pegmatites and $\mathrm{W}$ mineralized quartz veins.

3. The $30^{\circ} \mathrm{N}-40^{\circ} \mathrm{E}$ and its conjugate $150^{\circ} \mathrm{N}-160^{\circ} \mathrm{E}$ are well represented in the study area by the regional quartz veins with post-Variscan $\mathrm{U}$ mineralizations.

\subsection{Mineralizations}

The "Iberian Sn-W metallogenic province" [33], included in the "Northern mineralogenic province" [34], is located in the Variscan Iberian belt and is characterized by the occurrence of several W and Sn ore deposits. The Sn and W primary ore deposits are related to magmatic-hydrothermal systems commonly associated with granites. The magmatic differentiation processes promote the concentration of $\mathrm{W}$ and $\mathrm{Sn}$ in the residual evolved melts, which later precipitate in the apical granitic zones. In $\mathrm{N}$ and Central Portugal, Sn mineralizations are mainly associated with peraluminous two-micas granites and $\mathrm{W}$ mineralizations associated with biotite rich granites $([36,37]$ and the references therein).

The FSEC region, part of the Iberian $\mathrm{Sn}-\mathrm{W}$ metallogenic province, is characterized by several Sn and $\mathrm{W}$ occurrences (Figure 2). The spatial distribution of the distinct types of mineralizations is not accidental. The Panasqueira mine, which is currently active, is one of the most important W-Sn ore deposits in the world. Its mineralization is associated with a greisen cupola related to the depth of the granitic body. Mineralization occurs in sub-horizontal quartz veins that fill a network of sub-horizontal joints in the metasedimentary sequences of SGC.

\section{Materials and Methods}

\subsection{Sampling Procedure}

Sampling for the petrographic and Anisotropy of Magnetic Susceptibility (AMS) analyses was carried out using the Capinha granite; 30 sites were sampled with a total of 227 oriented cores (Figure 3). For the whole rock geochemistry, two samples were collected from an active quarry (Q1 and Q2). The geographic distribution of the sampling was conditioned according to the difficult accessibility of outcrops and the weathering degree. The geographic coordinates of each sampling site are presented in Table A1 and Figure A1. Nevertheless, an attempt was made to homogenize sampling across the CG (about $\sim 1$ sampling site $/ 0.23 \mathrm{~km}^{2}$ ). At each site, 4 or 5 cylinders $25 \mathrm{~mm}$ in diameter were drilled using a Stihl petrol-powered portable drill and oriented in situ using a magnetic compass corrected to the local magnetic declination $\left(\sim 1^{\circ} 47^{\prime} \mathrm{W}\right)$. 


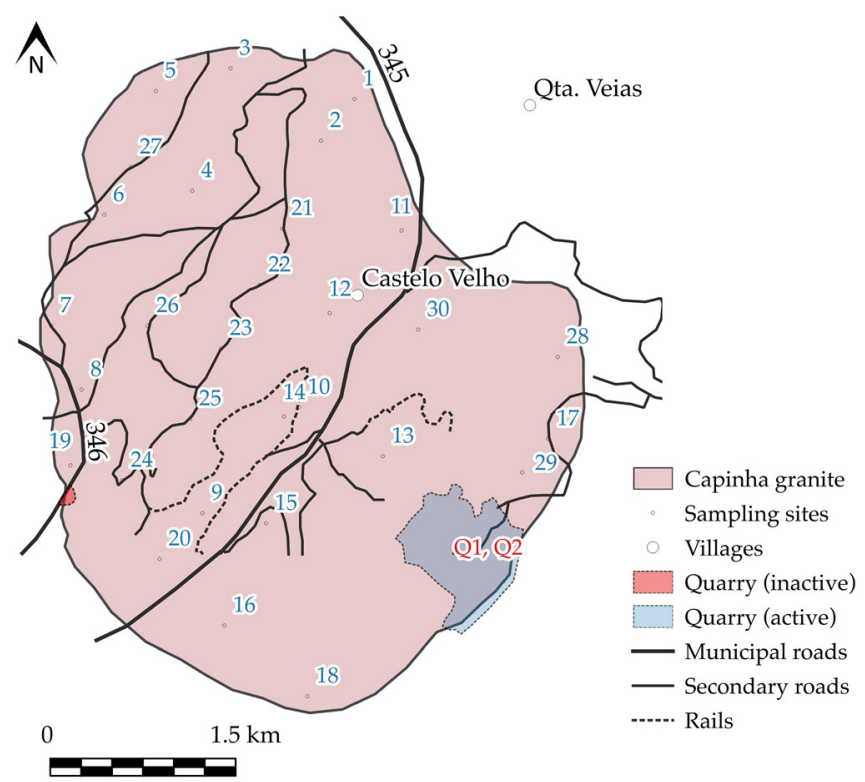

Figure 3. Location of the sampling sites for petrographic, anisotropy of magnetic susceptibility and whole rock geochemistry studies in Capinha granite.

\subsection{Petrography and Microstructures}

For petrographic, microstructural and microfracture studies, thin sections were taken from selected oriented cores. Petrography was then performed using a Zeiss Stemi SV11 Apo stereomicroscope coupled with a Sony Cyber-Shot DSC-S75 digital camera using a Leica DM LSP polarizing microscope with transmitted and reflected light, coupled with a Leica camera with the LAS EZ software 2.0.0 at the Department of Geosciences, Environment and Spatial Planning, and Institute of Earth Sciences (Faculty of Sciences, University of Porto). The study of opaque mineralogy was performed with a scanning electron microscope/energy dispersive x-ray spectroscope (SEM-EDS) at the Department of Geosciences, Environment and Spatial Planning, and Institute of Earth Sciences (Faculty of Sciences, University of Porto) using a FLEXSEM1000. The SEM-EDS was operated at $10.00 \mathrm{kV}$ in the low-vacuum mode, with a manual aperture and 4.5 beam spot sizes. The abbreviations used to identify the different mineral phases followed the nomenclature proposed in [85].

\subsection{Whole Rock Geochemistry}

The whole rock chemical compositions of the 8 crushed samples from CG $(95 \%<74 \mu \mathrm{m})$ were analyzed for their major $\left(\mathrm{SiO}_{2}, \mathrm{TiO}_{2}, \mathrm{Al}_{2} \mathrm{O}_{3}, \mathrm{Fe}_{2} \mathrm{O}_{3}, \mathrm{FeO}, \mathrm{MnO}, \mathrm{MgO}, \mathrm{CaO}, \mathrm{Na}_{2} \mathrm{O}, \mathrm{K}_{2} \mathrm{O}\right.$ and $\left.\mathrm{P}_{2} \mathrm{O}_{5}\right)$, trace $(\mathrm{Nb}, \mathrm{Zn}, \mathrm{Sn}, \mathrm{Zr}, \mathrm{Y}, \mathrm{Sr}, \mathrm{Ba}, \mathrm{Rb}$, Th and $\mathrm{W})$, and rare-earth elements ( $\mathrm{La}, \mathrm{Ce}, \mathrm{Nd}, \mathrm{Sm}, \mathrm{Eu}, \mathrm{Gd}, \mathrm{Tb}, \mathrm{Dy}$, $\mathrm{Ho}, \mathrm{Er}, \mathrm{Tm}, \mathrm{Yb}$ and $\mathrm{Lu}$ ) at Activation Laboratories Lda., Ontario, Canada. The samples were fused using lithium metaborate $\left(\mathrm{LiBO}_{2}\right)$ and digested using a nitric acid solution $\left(\mathrm{HNO}_{3}\right)$. Solutions were analyzed by inducing coupled plasma optical emission spectrometry (ICP-OES) for major elements, ICP mass spectrometry (ICP-MS) for trace- and rare earth elements and titration (TITR) for FeO. The loss on ignition (LOI) was determined gravimetrically using a precision scale. The uncertainties of major elements were generally between $1 \%$ and $3 \%$, whereas most of the trace elements had uncertainties below $10 \%$. More information about the ICP-OES, ICP-MS and TITR analytical procedures, precision values and limits of detection is given by the Activation Laboratories Lda. official page [86].

\subsection{Anisotropy of Magnetic Susceptibility}

AMS measurements were performed on 160 oriented specimens using a KLY-4S Kappabridge susceptometer $\left( \pm 3.8 \times 10^{-4} \mathrm{~T}\right.$; AGICO Ltd., Brno, Czech Republic) at the Department of Geosciences, Environment and Spatial Planning and the Institute of Earth Sciences (Faculty of Sciences, University 
of Porto) operating at room temperature with a $300 \mathrm{~A} / \mathrm{m}$ AC field at $920 \mathrm{~Hz}$. Using a sequence of 15 susceptibility measurements along different orientations for each specimen allowed us to compute the orientation and magnitude of the three main axes $\left(K_{1} \geq K_{2} \geq K_{3}\right)$ of the AMS ellipsoid by applying Jelinek statistics [87]. Tensor reconstruction and statistical analyses were made using the ANISOFT 4.2 software [88]. AMS defines the magnetic susceptibility tensor that correlates the strength of the applied field, $H(\mathrm{~A} / \mathrm{m})$, to the acquired magnetization, $M(\mathrm{~A} / \mathrm{m})$, of a material, expressed by the mathematic equation:

$$
M=K H
$$

Thus, the $K$ or $K_{\mathrm{m}}$ (dimensionless in SI units) is a 2nd-rank tensor originating from a symmetric matrix that describes the spatial variation of magnetic susceptibility (e.g., [8]). This tensor is expressed by the magnitude (eigenvalues) and orientation (eigenvectors) of the maximum $\left(K_{1}\right)$, intermediate $\left(K_{2}\right)$ and minimum $\left(K_{3}\right)$ principal axes of the magnetic ellipsoid. The mean magnetic susceptibility is calculated according to the follow equation:

$$
K_{\mathrm{m}}=\frac{K_{1}+K_{2}+K_{3}}{3} .
$$

An AMS ellipsoid is a geometrical representation of such a tensor, where $K_{1}$ represents magnetic lineation and $K_{3}$ is the pole of magnetic foliation (e.g., [8,20]). The shape of the magnetic susceptibility ellipsoid is represented by the shape parameter $(T)$ from [84], expressed by

$$
\begin{gathered}
T=\frac{\ln (F)-\ln (L)}{\ln (F)+\ln (L)} \\
F=\ln \left(\frac{K_{2}}{K_{3}}\right) \\
T=\ln \left(\frac{K_{1}}{K_{2}}\right)
\end{gathered}
$$

where $F$ is planar anisotropy and $L$ is linear anisotropy, which can be $T=+1$ (pure planar or oblate ellipsoid), $T=-1$ (pure linear or prolate ellipsoid) or $T=0$ (triaxial ellipsoid). The magnitude of the anisotropy degree $(P)$ corresponds to $K_{1} / K_{3}$. This study uses the parameter $P_{\text {para }}$ :

$$
P_{\text {para }} \%=100 \times\left[\left(\frac{K_{1}-K_{d}}{K_{3}-K_{d}}\right)-1\right]
$$

where $K_{\mathrm{d}}$ corresponds to the diamagnetic components of quartz and feldspar [18]. This parameter, $P_{\text {para }}$, is more realistic than $P$ for rocks with paramagnetic behavior, thus making it necessary to subtract $K_{\mathrm{d}}$, which is constant $\left(-14.6 \times 10^{-5} \mathrm{SI}\right)$ and isotropic, to avoid artificial enhancement of paramagnetic anisotropy [89].

\subsection{Fracturing}

The samples used in microfracturing studies have neither strong superficial alterations nor (generally) hand fractures. The strikes of the microfractures (or fluid inclusion planes, FIP) were measured on each oriented thin section using the PLANIF program [90,91]. For the microfracturing study, we considered intergranular and intercrystalline microfractures [92] healed by secondary fluid inclusions $[93,94]$ without evidence of lateral movement. Statistical interpretation of the data was made using rose diagrams, in which the microcracks are given in $10^{\circ}$ classes using the "Stereonet 10.0.6 64-bit version" program [95-97]. 


\section{Results}

\subsection{Main Petrographic and Mineralogic Features}

\subsubsection{Petrography and Microstructural Study}

The CG displays a typical hypidiomorphic inequigranular medium- to fine-grained texture. The petrography allowed us to identify the presence of quartz, alkali feldspar (microcline $>>$ orthoclase) and plagioclase (albite-oligoclase), comprising $36.45 \%, 26 \%$ and $26.64 \%$ of the total normative composition, respectively (Table 2). Muscovite, biotite, chlorite, apatite, rutile, zircon, monazite and opaque minerals are ubiquitous accessory minerals. A complete petrographic and microstructural description of the studied samples is provided in Table 3 and illustrative microphotographs are presented in Figure 4.

Table 2. Normative Cross-Iddings-Pirsson-Washington (CIPW) composition of the Capinha granite. Nomenclature [85]: Qz—quartz; Pl—plagioclase; Or—orthoclase; Crn—corundum; Hyp—hypersthene; Ilm—ilmenite; Mag—magnetite; Hem-hematite; Ap—apatite. Min—minimum; Max—maximum; $\bar{x}$-average; $\sigma$-standard deviation; $\mathrm{n}$-number of samples.

\begin{tabular}{ccccc}
\hline \multirow{2}{*}{ Mineral\% } & \multicolumn{4}{c}{ Capinha Granite $(\boldsymbol{n}=\mathbf{8})$} \\
\cline { 2 - 5 } & Min & Max & $\bar{x}$ & $\boldsymbol{\sigma}$ \\
\hline Qz & 35.29 & 37.58 & 36.45 & 0.7 \\
Pl & 25.31 & 28.26 & 26.64 & 1 \\
Or & 25.18 & 26.69 & 26 & 0.52 \\
Crn & 3.93 & 5.34 & 4.68 & 0.4 \\
Hyp & 1.02 & 3.47 & 2.19 & 0.75 \\
Ilm & 0.4 & 0.66 & 0.45 & 0.08 \\
Mag & 0.49 & 1.83 & 1.1 & 0.45 \\
Hem & 0 & 1.35 & 0.17 & 0.45 \\
Ap & 0.53 & 0.88 & 0.8 & 0.11 \\
\hline
\end{tabular}


Table 3. Mineralogy and microstructures associated with the growth and deformation of minerals in the CG. The distinguished domains were defined by considering a distinct range of temperatures, namely, (i) a magmatic to submagmatic state for felsic magmas: $\mathrm{T}>750{ }^{\circ} \mathrm{C}[3,98]$ and (ii) a solid state at a low-temperature: $\mathrm{T}<400{ }^{\circ} \mathrm{C}$ [99]. Nomenclature [85]: Quartz (Qz), Orthoclase (Or), Microcline (Mc), Albite (Ab), Biotite (Bt), Chlorite (Chl), Muscovite (Ms), Zircon (Zrn), Apatite (Ap), Rutile (Rt).

\begin{tabular}{|c|c|c|c|c|}
\hline Mineral & Occurrence & Magmatic to Submagmatic & Low-T Solid State & Other Observations \\
\hline Quartz (Qz) & $\begin{array}{l}\text { Anhedral to subhedral } \\
\text { inequigranular crystals; very variable } \\
\text { sizes ranging from a few } \mu \mathrm{m} \text { up to } \\
500 \mu \mathrm{m} \text {. }\end{array}$ & $\begin{array}{l}\text { No preferred orientation; inclusions } \\
\text { in other igneous crystals; evident } \\
\text { undulose extinction (Figure } 4 a \text { ). }\end{array}$ & $\begin{array}{l}\text { Scarce subgranulation and sutured } \\
\text { boundaries with recrystallized bulges } \\
\text { (Figure 4b); strongly fractured } \\
\text { (Figure 4c). }\end{array}$ & $\begin{array}{l}\text { Local, poorly defined chess-board patterns } \\
\text { are present. }\end{array}$ \\
\hline K feldspar & $\begin{array}{l}\text { The orthoclase (Or) and microcline } \\
\text { (Mc) occur in well-developed crystals; } \\
\text { microcline is more abundant than } \\
\text { orthoclase and exhibits crystals up to } \\
500 \mu \mathrm{m} \text {. Orthoclase occurs in small } \\
\text { crystals, ca. } 200 \mu \mathrm{m} \text {. }\end{array}$ & $\begin{array}{l}\text { Eu- to subhedral crystals; growth } \\
\text { twins common in both K feldspars; } \\
\text { orthoclase displays perthites, venules } \\
\text { and bands (Figure } 4 \mathrm{~d} \text { ); eu- to } \\
\text { subhedral inclusions in other igneous } \\
\text { crystals, generally albite-oligoclase. }\end{array}$ & $\begin{array}{l}\text { Slightly glide and/or deformed twins } \\
\text { (Figure 4e); altered to fine-grained } \\
\text { white micas (sericitization). }\end{array}$ & $\begin{array}{l}\text { Occasionally, the orthoclase is replaced by } \\
\text { microcline, displaying Carlsbad twins } \\
\text { together with cross-hatched twins } \\
\text { (Figure } 4 \mathrm{f}) ; \text { microcline and orthoclase } \\
\text { exhibit a poikilitic texture characterized by } \\
\text { small inclusions of quartz, orthoclase and } \\
\text { micas. }\end{array}$ \\
\hline Plagioclase (Pl) & $\begin{array}{l}\text { Plagioclase, namely, albite-oligoclase, } \\
\text { occurs in well-developed crystals } \\
(\geq 500 \mu \mathrm{m}) .\end{array}$ & $\begin{array}{l}\text { Eu- to subhedral crystals; slightly } \\
\text { zoned (oscillatory); growth twins } \\
\text { common parallel to the long axis; eu- } \\
\text { to subhedral inclusions in other } \\
\text { igneous crystals, generally, in the } \\
\text { microcline. }\end{array}$ & $\begin{array}{l}\text { Strongly altered to very fine-grained } \\
\text { white micas (sericitization) and clays } \\
\text { (Figure } 4 \mathrm{~g}) \text {; deformed twins } \\
\text { (Figure } 4 \mathrm{~h} \text { ); fracturing infilled by iron } \\
\text { oxides. }\end{array}$ & $\begin{array}{l}\text { Sporadically, metal phases occur associated } \\
\text { with the plagioclase; commonly, the } \\
\text { replacement of the albite-oligoclase } \\
\text { develops through the zoning planes } \\
\text { (Figure 4i). }\end{array}$ \\
\hline Phyllosilicates & $\begin{array}{l}\text { Three types were identified: primary } \\
\text { muscovite (Ms I, the most abundant), } \\
\text { biotite (Bt) and chlorite (Chl) } \\
\text { (Figure 4j). They occur in anhedral to } \\
\text { subhedral crystals with frayed ends, } \\
\text { isolated or in clusters of several } \\
\text { flakes; sizes ranging between } 100 \text { and } \\
\quad 500 \mu \mathrm{m} \text {. }\end{array}$ & $\begin{array}{l}\text { Ms and Bt are, generally, subhedral, } \\
\text { with well-defined cleavage; randomly } \\
\text { distributed; eu- to subhedral } \\
\text { inclusions in other igneous crystals. }\end{array}$ & $\begin{array}{c}\text { Muscovite presents slight } \\
\text { deformation (kinking) (Figure 4k); } \\
\text { biotite is, frequently, replaced by } \\
\text { chlorite and also by secondary } \\
\text { muscovite (Ms II). }\end{array}$ & $\begin{array}{l}\text { Inclusions of small clusters of eu- to } \\
\text { subhedral zircons (lengths lower than } 50 \\
\mu \mathrm{m} \text { ) in Bt, promoting the origin of } \\
\text { pleochroic halos; inclusions of subhedral } \\
\text { platy crystals of ilmenite (sizes lower than } \\
100 \mu \mathrm{m}) \text { parallel to the cleavage planes of } \\
\text { biotite and/or chlorite; very fine-grained } \\
\text { reeds of rutile (lower than } 30 \mu \mathrm{m} \text { in length) } \\
\text { associated with the chloritization of Bt; } \\
\text { inclusions of apatite }(100 \text { to } 200 \mu \mathrm{m}) \text { and } \\
\text { monazite (<30 }<\mathrm{m} \text { ) in Bt, showing } \\
\text { euhedral to subhedral shapes (Figure 4l). }\end{array}$ \\
\hline
\end{tabular}



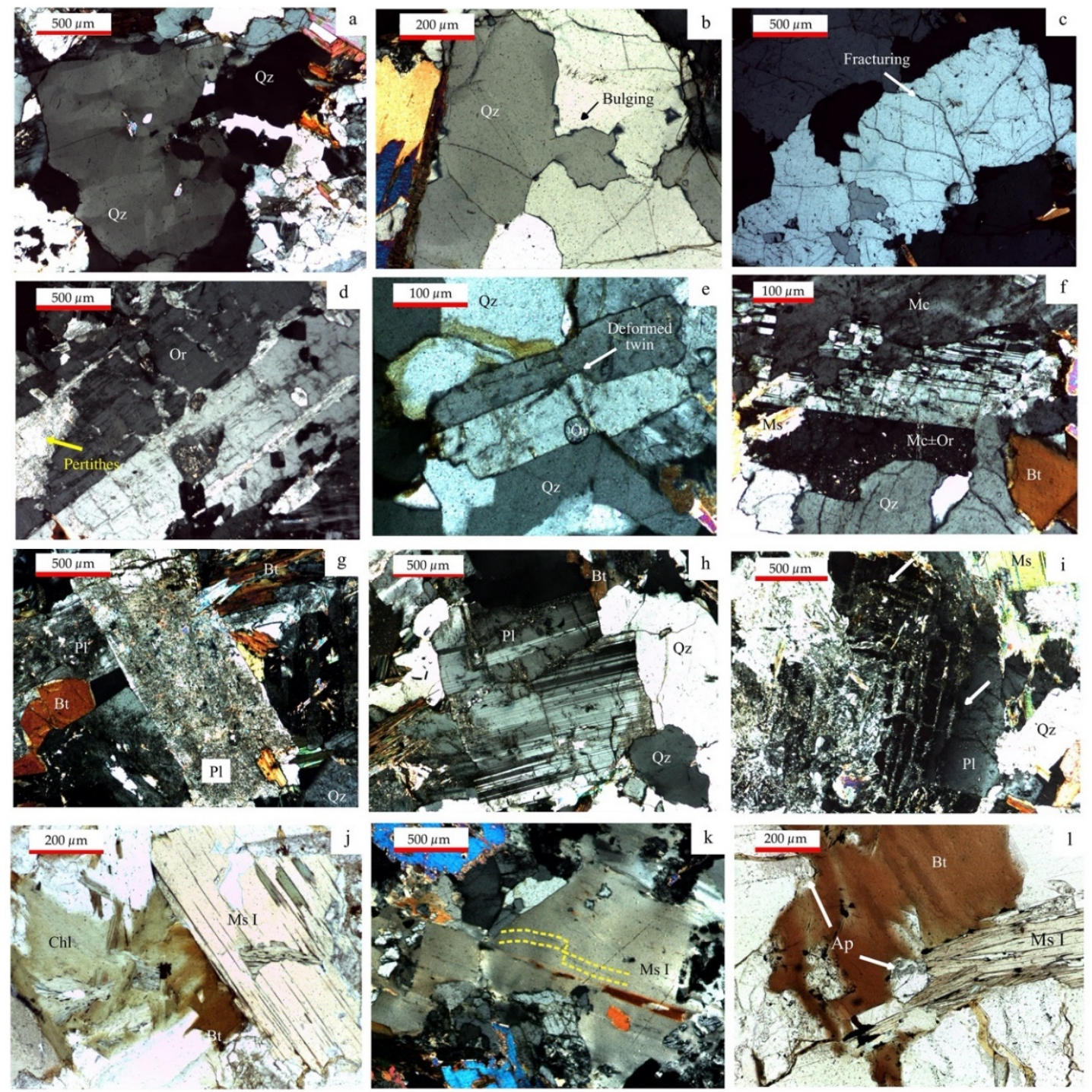

Figure 4. Microstructures and textural features observed in the main and accessory mineralogy. $(\mathbf{a}-\mathbf{c})$ Quartz: undulose extinction (a), sutured boundaries with recrystallized bulges (b) and strong fracturing (c); (d-f) K feldspar: orthoclase displaying perthites (d), deformed twins (e) and the replacement of orthoclase with microcline, displaying Carlsbad twins together with cross-hatched twins (f); (g-i) plagioclase strongly altered to very fine-grained white micas (sericitization) and clays (g), evidence of deformed twins (h) and alterations in albite-oligoclase developing through the zoning planes (i); (j-l) micas: relationships between primary muscovite (Ms I), biotite (Bt) and chlorite (Chl) (j); slight deformation of muscovite cleavages (k); and inclusions of apatite (100 to $200 \mu \mathrm{m})$ in Bt (1). (microphotographs $\mathbf{a}, \mathbf{b}, \mathbf{c}, \mathbf{d}, \mathbf{e}, \mathbf{f}, \mathbf{g}, \mathbf{h}, \mathbf{I}$ and $\mathbf{k}$ ) taken under cross polarized light (CPL). (microphotographs $\mathbf{j}$ and $\mathbf{l}$ ) taken under plane polarized light (PPL).

\subsubsection{Magnetic Mineralogy}

The magnetic mineralogy was investigated in CG using optical microscopy under reflected light and SEM-EDS. The petrography of the CG revealed the prevalent occurrence of paramagnetic minerals (biotite and opaque phases). The opaque mineralogy is dominated by ubiquitous ilmenite and subordinate amounts of pyrite, arsenopyrite and hematite. Ilmenite is mainly found as eu- to subhedral grains, which are generally optically homogeneous. These grains are usually associated with phyllosilicates (mainly, biotite) that have undergone alteration: (1) small $(\sim 50 \mu \mathrm{m})$ and elongated segregations along the basal section of the biotite (Figure 5a) and/or chloritized biotites and (2) small 
(50 to $100 \mu \mathrm{m}$ ) patches that are generally associated with apatite in the matrix (Figure 5b-d). Pyrite is also observed as irregular crystals associated with apatite in connection with a widespread and usually strong, alteration of the plagioclase $(\sim 500 \mu \mathrm{m})$, (Figure $5 \mathrm{e})$. Little arsenopyrite appears in the eu- to subhedral crystals $(\sim 100 \mu \mathrm{m})$ disseminated in the matrix (Figure 5f).

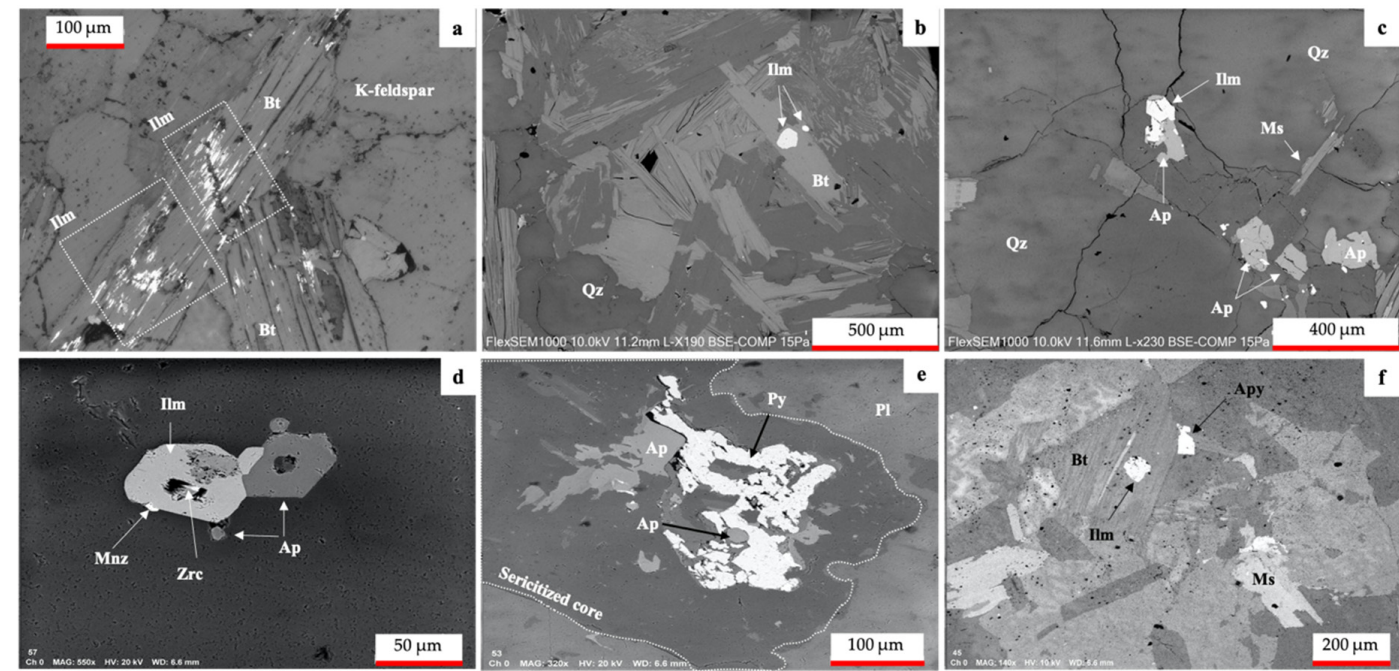

Figure 5. Opaque mineralogy and mineral associations. (a-d) General aspects of the distinct modes of occurrence of ilmenite (Ilm) in the small elongated crystals included in the biotite cleavages (a), larger single euhedral crystals (b) and crystals associated with apatite, zircon and monazite (c) and (d); (e) large anhedral crystals $(>100 \mu \mathrm{m})$ of pyrite (Py) associated with apatite in the sericitized core of the plagioclase (albite-oligoclase); (f) anhedral crystals of arsenopyrite (Apy, ca. $100 \mu \mathrm{m}$ ) in the matrix. All the microphotographs were taken using a high-contrast backscattered electron (BSE) analysis, except for (a), which was taken under reflected light.

\subsubsection{Capinha Granite: Geochemical Characterization}

Representative data of the major, trace and rare earth elements from the Capinha granite are reported in Tables 4 and 5. Samples 1, 4, 11, 15, 18 and 19 were collected at the outcrop surface (568 m altitude) and samples Q1 and Q2 were collected from a new quarry located in the southeastern boundary, at a depth of $87 \mathrm{~m}$ (481 m altitude). The whole rock composition shows that the granite is strongly homogeneous in the whole outcrop surface and also in depth (Figures 6 and 7). The CG is characterized by $\mathrm{SiO}_{2}$ contents ranging between $72.07 \mathrm{wt} \%$ and $73.41 \mathrm{wt} \%$ (Figure $6 \mathrm{a}, \mathrm{b}$ ) and $\mathrm{Al}_{2} \mathrm{O}_{3}$ contents from $14.33 \mathrm{wt} \%$ to $15.1 \mathrm{wt} \%$. (Table 4$)$. The $\mathrm{CG}$ is enriched in $\mathrm{K}_{2} \mathrm{O}(4.26 \mathrm{wt} \%-4.5 \mathrm{wt} \%)$ and $\mathrm{P}_{2} \mathrm{O}_{5}$ $(0.33 w t \%-0.38 w t \%)$. On the other hand, the CG is impoverished in $\mathrm{Fe}_{2} \mathrm{O}_{3}(0.55 \mathrm{wt} \%-1.69 \mathrm{wt} \%), \mathrm{FeO}$ $(0.3 w t \%-1.5 w t \%), \mathrm{CaO}(0.5 w t \%-0.73 w t \%), \mathrm{NaO}_{2}(2.93 w t \%-3.32 w t \%)$ and $\mathrm{TiO}_{2}(0.21 w t \%-0.23 w t \%)$ compared to the world average granite composition (WAGC) $[99,100]$ (Table 4). For trace elements, the CG is depleted in Sr (61-74 ppm), Y (11-13 ppm), Zr (71-79 ppm), Nb (9-10 ppm), Ba (239-263 ppm), Ta (2-2.3 ppm) and Th (6.3-7.2 ppm) (Table 4). In contrast, the CG is enriched in Rb (239-268 ppm), Sn (9-24 ppm), W (6-12 ppm) and U (10.1-15.8 ppm). The K/Rb ratio ranges from 131.96 to 149.02. 
Table 4. Major (wt \%) and trace (ppm) element data for Capinha granite. Notes: (1) when the analyzed values are below the lower limit, the values are considered half the lower limit's value; (2) the major and trace elements of the world average granite composition (WAGC) were compiled from the literature [100,101]. LOI-lost on ignition; --not determined; Min-minimum; Max-maximum; $\bar{x}$-average; $\sigma$ —standard deviation.

\begin{tabular}{|c|c|c|c|c|c|c|c|c|c|c|c|c|c|}
\hline \multirow{2}{*}{ Element } & \multicolumn{8}{|c|}{ Capinha Granite } & \multirow{2}{*}{ Min } & \multirow{2}{*}{$\operatorname{Max}$} & \multirow{2}{*}{$\bar{x}$} & \multirow{2}{*}{$\sigma$} & \multirow{2}{*}{ WAGC } \\
\hline & 1 & 4 & 11 & 15 & 18 & 19 & Q1 & Q2 & & & & & \\
\hline $\mathrm{SiO}_{2}$ & 72.57 & 73.34 & 72.07 & 72.87 & 72.44 & 73.41 & 72.76 & 72.61 & 72.07 & 73.41 & 72.76 & 0.42 & 72.04 \\
\hline $\mathrm{Al}_{2} \mathrm{O}_{3}$ & 14.82 & 14.97 & 14.33 & 15.1 & 14.97 & 14.75 & 14.94 & 14.51 & 14.33 & 15.1 & 14.8 & 0.24 & 14.42 \\
\hline $\mathrm{Fe}_{2} \mathrm{O}_{3}$ & 0.97 & 0.66 & 1.69 & 1.04 & 1.26 & 1.03 & 0.89 & 0.55 & 0.55 & 1.69 & 1.01 & 0.33 & 1.22 \\
\hline $\mathrm{FeO}$ & 1.1 & 1.3 & 0.3 & 1 & 0.8 & 1.1 & 1.2 & 1.5 & 0.3 & 1.5 & 1.04 & 0.34 & 1.68 \\
\hline $\mathrm{MgO}$ & 0.5 & 0.44 & 0.41 & 0.51 & 0.44 & 0.54 & 0.67 & 0.67 & 0.41 & 0.67 & 0.52 & 0.09 & 0.71 \\
\hline $\mathrm{CaO}$ & 0.54 & 0.6 & 0.6 & 0.5 & 0.62 & 0.73 & 0.61 & 0.63 & 0.5 & 0.73 & 0.6 & 0.06 & 1.82 \\
\hline $\mathrm{Na}_{2} \mathrm{O}$ & 2.96 & 3.08 & 3.22 & 3.01 & 3.32 & 3.19 & 3 & 2.93 & 2.93 & 3.32 & 3.09 & 0.13 & 3.69 \\
\hline $\mathrm{K}_{2} \mathrm{O}$ & 4.5 & 4.38 & 4.48 & 4.33 & 4.26 & 4.29 & 4.5 & 4.44 & 4.26 & 4.5 & 4.4 & 0.09 & 4.12 \\
\hline $\mathrm{P}_{2} \mathrm{O}_{5}$ & 0.37 & 0.38 & 0.35 & 0.33 & 0.37 & 0.36 & 0.35 & 0.36 & 0.33 & 0.38 & 0.36 & 0.01 & 0.12 \\
\hline LOI & 1.25 & 1.32 & 1.05 & 1.26 & 0.98 & 1.02 & 1.34 & 1.56 & 0.98 & 1.56 & 1.22 & 0.18 & n.d. \\
\hline Total & 99.86 & 100.7 & 98.76 & 100.2 & 99.72 & 100.7 & 100.5 & 100 & - & - & - & - & 100.17 \\
\hline Sc & 5 & 5 & 5 & 5 & 5 & 5 & 5 & 5 & 5 & 5 & 5 & 0 & - \\
\hline Be & 4 & 4 & 4 & 4 & 6 & 4 & 4 & 4 & 4 & 6 & 4.25 & 0.66 & - \\
\hline V & 22 & 23 & 20 & 21 & 20 & 22 & 23 & 22 & 20 & 23 & 21.63 & 1.11 & - \\
\hline $\mathrm{Cr}$ & 150 & 160 & 150 & 160 & 160 & 180 & 170 & 170 & 150 & 180 & 162.5 & 9.68 & - \\
\hline Co & 5 & 4 & 3 & 2 & 7 & 4 & 4 & 4 & 2 & 7 & 4.13 & 1.36 & - \\
\hline $\mathrm{Ni}$ & $<20$ & 60 & $<20$ & $<20$ & 20 & 30 & $<20$ & $<20$ & 20 & 60 & 36.67 & 17 & - \\
\hline $\mathrm{Cu}$ & $<10$ & 40 & 10 & 30 & $<10$ & $<10$ & $<10$ & $<10$ & 10 & 40 & 26.67 & 12.47 & - \\
\hline $\mathrm{Zn}$ & 70 & 50 & 60 & 50 & 90 & 60 & 60 & 60 & 50 & 90 & 62.5 & 11.99 & 39 \\
\hline As & 18 & 16 & 72 & 42 & 49 & 19 & 44 & 42 & 16 & 72 & 37.75 & 17.99 & - \\
\hline $\mathbf{R b}$ & 258 & 247 & 258 & 249 & 268 & 239 & 253 & 248 & 239 & 268 & 252.50 & 8.26 & 170 \\
\hline $\mathrm{Sr}$ & 72 & 68 & 74 & 64 & 69 & 70 & 61 & 61 & 61 & 74 & 67.38 & 4.58 & 100 \\
\hline $\mathrm{Y}$ & 13 & 13 & 11 & 13 & 13 & 12 & 12 & 11 & 11 & 13 & 12.25 & 0.83 & 40 \\
\hline $\mathrm{Zr}$ & 76 & 79 & 78 & 77 & 71 & 77 & 77 & 77 & 71 & 79 & 76.5 & 2.24 & 175 \\
\hline $\mathrm{Nb}$ & 10 & 10 & 10 & 10 & 9 & 10 & 10 & 10 & 9 & 10 & 9.88 & 0.33 & 28 \\
\hline Mo & 2 & 3 & 2 & 2 & 3 & 3 & 2 & 3 & 2 & 3 & 2.5 & 0.5 & - \\
\hline $\mathrm{Ag}$ & $<0.5$ & $<0.5$ & $<0.5$ & $<0.5$ & $<0.5$ & $<0.5$ & $<0.5$ & $<0.5$ & - & - & - & - & - \\
\hline In & $<0.2$ & $<0.2$ & $<0.2$ & $<0.2$ & $<0.2$ & $<0.2$ & $<0.2$ & $<0.2$ & - & - & - & - & - \\
\hline Sn & 9 & 14 & 20 & 24 & 24 & 12 & 16 & 16 & 9 & 24 & 16.88 & 5.09 & 3 \\
\hline
\end{tabular}


Table 4. Cont

\begin{tabular}{|c|c|c|c|c|c|c|c|c|c|c|c|c|c|}
\hline \multirow{2}{*}{ Element } & \multicolumn{8}{|c|}{ Capinha Granite } & \multirow{2}{*}{ Min } & \multirow{2}{*}{$\operatorname{Max}$} & \multirow{2}{*}{$\bar{x}$} & \multirow{2}{*}{$\sigma$} & \multirow{2}{*}{ WAGC } \\
\hline & 1 & 4 & 11 & 15 & 18 & 19 & Q1 & Q2 & & & & & \\
\hline $\mathrm{Sb}$ & $<0.5$ & $<0.5$ & $<0.5$ & $<0.5$ & $<0.5$ & $<0.5$ & $<0.5$ & $<0.5$ & - & - & - & - & - \\
\hline Cs & 14.9 & 16.7 & 15.7 & 17.6 & 21.3 & 11.3 & 18.5 & 17.9 & 11.3 & 21.3 & 16.74 & 2.74 & - \\
\hline Ва & 263 & 250 & 261 & 241 & 248 & 247 & 239 & 239 & 239 & 263 & 248.5 & 8.72 & 340 \\
\hline W & 6 & 8 & 11 & 12 & 12 & 9 & 10 & 9 & 6 & 12 & 9.63 & 1.93 & 2.2 \\
\hline $\mathrm{Tl}$ & 1.6 & 1.4 & 1.6 & 1.5 & 1.7 & 1.5 & 1.5 & 1.5 & 1.4 & 1.7 & 1.54 & 0.09 & - \\
\hline $\mathrm{Pb}$ & 23 & 22 & 25 & 23 & 22 & 25 & 23 & 23 & 22 & 25 & 23.25 & 1.09 & - \\
\hline $\mathbf{B i}$ & $<0.4$ & 1.9 & 0.9 & 1.3 & 0.8 & 0.7 & 1.5 & 1.3 & 0.7 & 1.9 & 1.2 & 0.4 & - \\
\hline Th & 6.7 & 7 & 6.8 & 6.3 & 6.4 & 6.7 & 7.2 & 6.7 & 6.3 & 7.2 & 6.73 & 0.27 & 17 \\
\hline $\mathrm{Hf}$ & 2 & 2.2 & 2.2 & 2.1 & 2.3 & 2.3 & 2.1 & 2.1 & 2 & 2.3 & 2.16 & 0.1 & 3 \\
\hline $\mathbf{K} / \mathbf{R b}$ & 144.8 & 147.22 & 144.16 & 144.37 & 131.96 & 149.02 & 147.66 & 148.63 & 131.96 & 149.02 & 144.73 & 5.15 & - \\
\hline $\mathrm{Rb} / \mathrm{Sr}$ & 3.58 & 3.63 & 3.49 & 3.89 & 3.88 & 3.41 & 4.15 & 4.07 & 3.41 & 4.15 & 3.76 & 0.26 & - \\
\hline $\mathbf{R}_{1}$ & 3747 & 3792 & 3673 & 3779 & 3703 & 3786 & 3752 & 3762 & 3673 & 3792 & 3749.25 & 39.04 & - \\
\hline $\mathbf{R}_{2}$ & 227.93 & 232.85 & 225.08 & 226.89 & 234.99 & 249.56 & 245.03 & 242.96 & 225.08 & 249.56 & 235.66 & 8.60 & - \\
\hline A & 30.56 & 29.23 & 19.64 & 35.73 & 25.92 & 21.62 & 28.6 & 25.43 & 19.64 & 35.73 & 27.09 & 4.78 & - \\
\hline B & 28.99 & 27.02 & 25.48 & 28.91 & 27.01 & 30.28 & 33.5 & 33.42 & 25.48 & 33.5 & 29.33 & 2.76 & - \\
\hline $\mathrm{A} / \mathrm{CNK}$ & 1.38 & 1.37 & 1.28 & 1.43 & 1.34 & 1.31 & 1.37 & 1.35 & 1.28 & 1.43 & 1.35 & 0.04 & - \\
\hline A/NK & 1.52 & 1.53 & 1.41 & 1.57 & 1.49 & 1.49 & 1.52 & 1.51 & 1.41 & 1.57 & 1.51 & 0.04 & - \\
\hline
\end{tabular}

$\mathrm{R}_{1}=4 \mathrm{Si}-11(\mathrm{Na}+\mathrm{K})-2(\mathrm{Fe}+\mathrm{Ti}) ; \mathrm{R}_{2}=6 \mathrm{Ca}+\mathrm{Mg}+\mathrm{Al} ; \mathrm{A}=\mathrm{Al}-(\mathrm{K}+\mathrm{Na}+2 \mathrm{Ca}) ; \mathrm{B}=\mathrm{Fe}+\mathrm{Mg}+\mathrm{Ti} ;$ alumina saturation index: $\mathrm{molar} \mathrm{A} / \mathrm{CNK}=\mathrm{Al}{ }_{2} \mathrm{O}_{3} /\left(\mathrm{CaO}+\mathrm{Na} \mathrm{O}_{2}+\mathrm{K}_{2} \mathrm{O}\right) ; \mathrm{molar} \mathrm{A} / \mathrm{NK}=$ $\mathrm{Al}_{2} \mathrm{O}_{3}\left(\mathrm{Na}_{2} \mathrm{O}+\mathrm{K}_{2} \mathrm{O}\right)$ 
According to the classification proposed in [102], the CG reveals a magnesian association in its $\mathrm{Fe}$-number (or $\mathrm{Fe}^{*}$ ) versus $\mathrm{SiO}_{2}$ plot (adapted from [103]) and calc-alkalic to alkali-calcic association based on a modified alkali-lime index (MALI, modified from [104]) (Figure 6a,b respectively). The aluminum saturation index shows a moderated peraluminous character with a molar A/CNK index ranging from 1.28 to 1.43 [105]. The CG plots are included in the granite sensu stricto field in the $\mathrm{R}_{1}-\mathrm{R}_{2}$ diagram [106] (Figure 6c). The CG plots in the peraluminous field with muscovite $>$ biotite are presented in the B-A diagram [107] (Figure 6d), displaying affinities with the post-orogenic granites defined in [108]. Capinha granite is geochemically differentiated, as evidenced by its high $\mathrm{SiO}_{2}$ and low $\mathrm{CaO}, \mathrm{FeO}, \mathrm{MgO}$ and $\mathrm{TiO}_{2}$ contents; it is also enriched in $\mathrm{Sn}$ and $\mathrm{W}$.
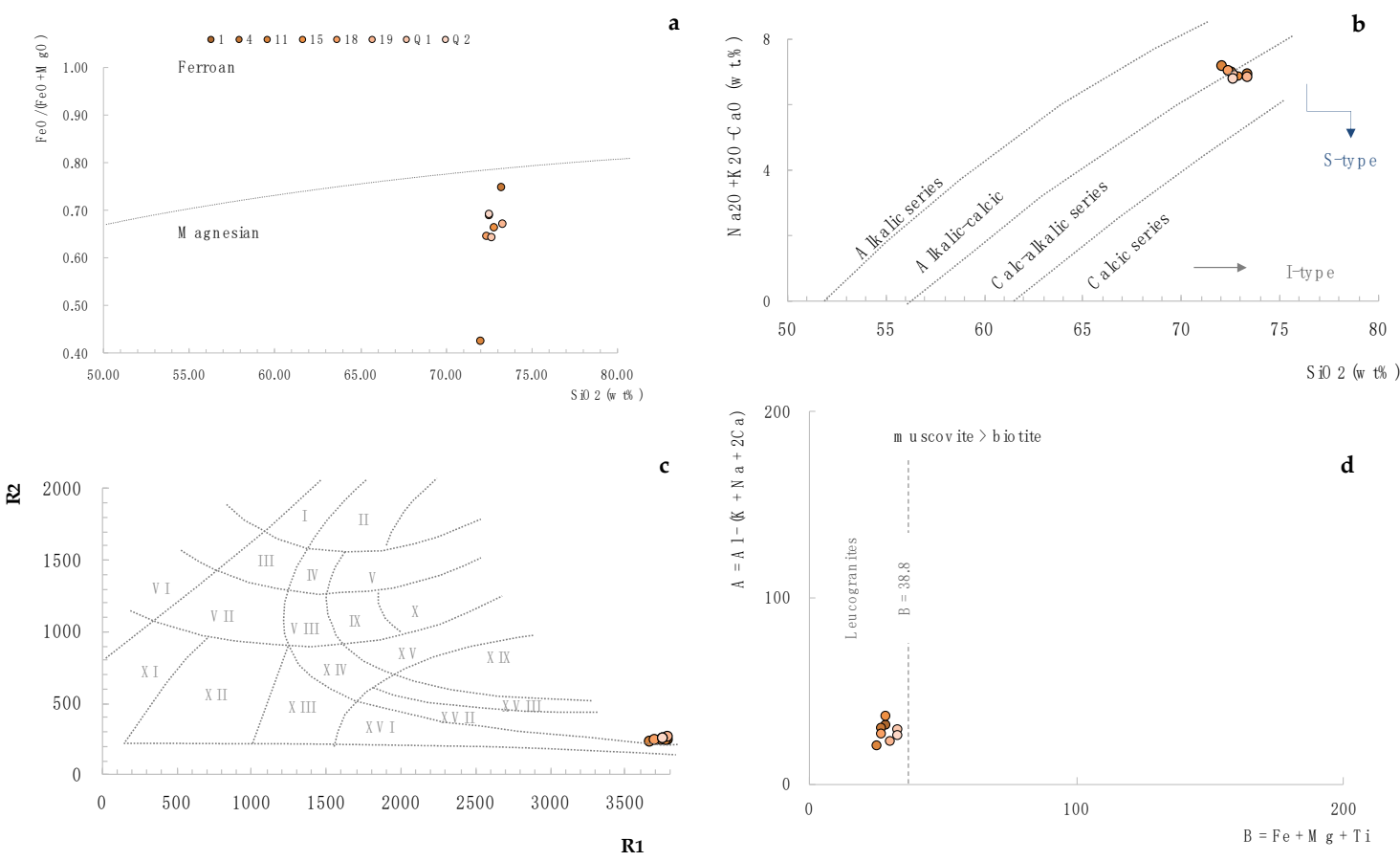

Figure 6. Geochemical classification of Capinha granite based on the major elements. (a) $\mathrm{FeO}^{(\mathrm{Tot})} / \mathrm{FeO}^{(\mathrm{Tot})}$ + $\mathrm{MgO}$ versus $\mathrm{SiO}_{2}$ [101]; (b) modified alumina-lime index (MALI) versus $\mathrm{SiO}_{2}$ classification [102]; (c) multicationic $\mathrm{R}_{1}-\mathrm{R}_{2}$ classification plot from [106]; (d) B-A diagram [107] showing the CG samples plotted in the leucogranites of the muscovite $>$ biotite field.

Table 5. Rare earth elements (REE, in ppm) of Capinha granite. The REE were normalized to chondrite according to [109]. REE(Tot) — the sum of all rare earth elements; $\mathrm{LREE}^{(\mathrm{Tot})}$ — the sum of all light rare earth elements; $\mathrm{HREE}^{(\mathrm{Tot})}$ — the sum of all heavy rare earth elements; $\mathrm{N}$ - the normalized ratio; Min-minimum; Max-maximum; $\bar{x}$-average; $\sigma$-standard deviation

\begin{tabular}{|c|c|c|c|c|c|c|c|c|c|c|c|c|}
\hline \multirow{2}{*}{ REE } & \multicolumn{8}{|c|}{ Capinha Granite } & \multirow{2}{*}{ Min } & \multirow{2}{*}{ Max } & \multirow{2}{*}{$\bar{x}$} & \multirow{2}{*}{$\sigma$} \\
\hline & 1 & 4 & 11 & 15 & 18 & 19 & Q1 & Q2 & & & & \\
\hline La & 15.8 & 15.3 & 14.1 & 13.7 & 14.2 & 14.1 & 14.9 & 14.3 & 13.7 & 15.8 & 14.55 & 0.67 \\
\hline $\mathrm{Ce}$ & 32.6 & 32.4 & 29.8 & 29.1 & 30.5 & 30.3 & 32 & 30.2 & 29.1 & 32.6 & 30.86 & 1.21 \\
\hline $\operatorname{Pr}$ & 3.71 & 3.78 & 3.47 & 3.26 & 3.54 & 3.58 & 3.64 & 3.51 & 3.26 & 3.78 & 3.56 & 0.15 \\
\hline Nd & 14.1 & 14.3 & 13.8 & 12.9 & 13.3 & 12.7 & 14.4 & 13.5 & 12.7 & 14.4 & 13.63 & 0.59 \\
\hline $\mathrm{Sm}$ & 3.2 & 3.4 & 3 & 2.9 & 3 & 2.9 & 3 & 3 & 2.9 & 3.4 & 3.05 & 0.16 \\
\hline Eu & 0.48 & 0.56 & 0.53 & 0.54 & 0.49 & 0.46 & 0.44 & 0.51 & 0.44 & 0.56 & 0.50 & 0.04 \\
\hline Gd & 2.9 & 3.3 & 2.8 & 2.9 & 3.3 & 2.6 & 2.7 & 2.9 & 2.6 & 3.3 & 2.93 & 0.24 \\
\hline $\mathrm{Tb}$ & 0.4 & 0.5 & 0.4 & 0.5 & 0.5 & 0.4 & 0.4 & 0.4 & 0.4 & 0.5 & 0.44 & 0.05 \\
\hline Dy & 2.5 & 2.8 & 2.3 & 2.3 & 2.5 & 2.3 & 2.4 & 2.2 & 2.2 & 2.8 & 2.41 & 0.18 \\
\hline Ho & 0.4 & 0.5 & 0.4 & 0.4 & 0.4 & 0.4 & 0.4 & 0.4 & 0.4 & 0.5 & 0.41 & 0.03 \\
\hline $\mathrm{Er}$ & 1.1 & 1.2 & 1.1 & 1.1 & 1.2 & 1 & 1 & 1 & 1 & 1.2 & 1.09 & 0.08 \\
\hline Tm & 0.16 & 0.16 & 0.16 & 0.18 & 0.16 & 0.14 & 0.16 & 0.14 & 0.14 & 0.18 & 0.16 & 0.01 \\
\hline $\mathrm{Yb}$ & 1 & 1 & 0.9 & 1.1 & 0.9 & 0.9 & 0.9 & 0.9 & 0.9 & 1.1 & 0.95 & 0.07 \\
\hline $\mathbf{L u}$ & 0.13 & 0.14 & 0.13 & 0.14 & 0.14 & 0.11 & 0.14 & 0.12 & 0.11 & 0.14 & 0.13 & 0.01 \\
\hline
\end{tabular}


Table 5. Cont.

\begin{tabular}{|c|c|c|c|c|c|c|c|c|c|c|c|c|}
\hline \multirow{2}{*}{ REE } & \multicolumn{8}{|c|}{ Capinha Granite } & \multirow{2}{*}{ Min } & \multirow{2}{*}{ Max } & \multirow{2}{*}{$\bar{x}$} & \multirow{2}{*}{$\sigma$} \\
\hline & 1 & 4 & 11 & 15 & 18 & 19 & Q1 & Q2 & & & & \\
\hline $\operatorname{REE}^{(\text {Tot })}$ & 78.48 & 79.34 & 72.89 & 71.02 & 74.13 & 71.89 & 76.48 & 73.08 & 71.02 & 79.34 & 74.66 & 2.89 \\
\hline $\operatorname{LREE}^{(\mathrm{Tot})}$ & 69.41 & 69.18 & 64.17 & 61.86 & 64.54 & 63.58 & 67.94 & 64.51 & 61.86 & 69.41 & 65.65 & 2.63 \\
\hline HREE $^{\text {(Tot) }}$ & 8.59 & 9.6 & 8.19 & 8.62 & 9.1 & 7.85 & 8.1 & 8.06 & 7.85 & 9.6 & 8.51 & 0.55 \\
\hline$(\mathrm{La} / \mathrm{Lu})_{\mathrm{N}}$ & 12.62 & 11.34 & 11.26 & 10.16 & 10.53 & 13.31 & 11.05 & 12.37 & 10.16 & 13.31 & 11.58 & 1.02 \\
\hline$(\mathrm{La} / \mathrm{Sm})_{N}$ & 3.11 & 2.83 & 2.96 & 2.97 & 2.98 & 3.06 & 3.13 & 3 & 2.83 & 3.13 & 3.01 & 0.09 \\
\hline$(\mathrm{Gd} / \mathrm{Lu})_{\mathrm{N}}$ & 2.77 & 2.93 & 2.68 & 2.57 & 2.93 & 2.94 & 2.4 & 3 & 2.4 & 3 & 2.78 & 0.20 \\
\hline$(E u / E u)_{N}$ & 0.24 & 0.25 & 0.28 & 0.28 & 0.24 & 0.25 & 0.23 & 0.26 & 0.23 & 0.28 & 0.25 & 0.02 \\
\hline
\end{tabular}
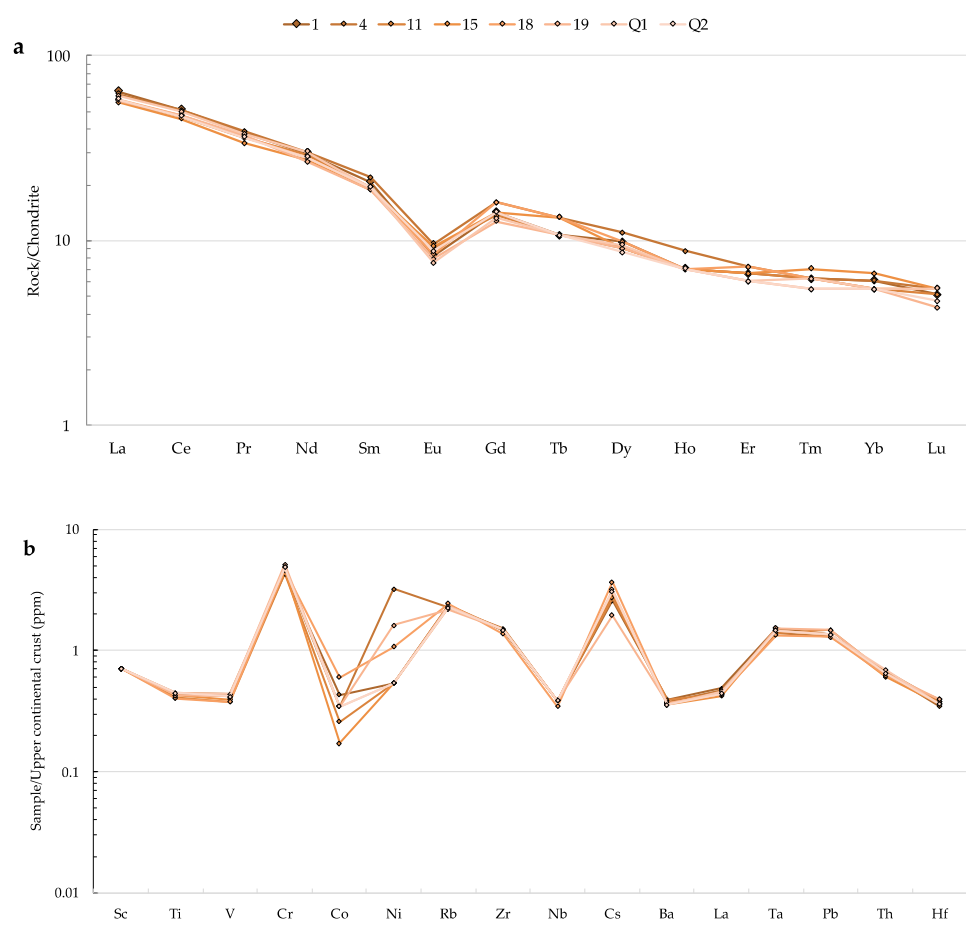

Figure 7. (a) Chondrite-normalized REE distribution patterns from the CG. Normalization values are from [109]; (b) multi-element diagram normalized to the upper continental crust (UCC) for CG samples. Normalization values are from [110].

The chondrite normalized REE patterns [109] for the CG showed very similar spectra profiles (Table 5), demonstrating a strong overlap in light rare earth elements (LREE) compared to heavy rare earth elements (HREE) (Figure 7). The LREE and HREE are slightly fractionated here, corresponding to $(\mathrm{La} / \mathrm{Sm})_{\mathrm{N}}=2.83$ to 3.13 and $(\mathrm{Gd} / \mathrm{Lu})_{\mathrm{N}}=2.4$ to 3 , respectively. The CG is enriched in $\mathrm{LREE}^{(\mathrm{Tot})}$ (61.86-69.41 ppm) compared to $\operatorname{HREE}^{(\mathrm{Tot})}$ (7.85-9.6 ppm), showing moderated REE fractionation, with $(\mathrm{La} / \mathrm{Lu})_{\mathrm{N}}$ ranging from 10.16 to 13.31 and a small negative anomaly in $\mathrm{Eu}\left(\mathrm{Eu} / \mathrm{Eu}^{*}\right)_{\mathrm{N}}$, ranging between 0.23 and 0.28 .

Multi-element diagram normalized to the upper continental crust [110] (Figure 7b) show similar patterns and a remarkable overlap of all CG samples, with positive $\mathrm{Cr}, \mathrm{Rb}, \mathrm{Zr}, \mathrm{Cs}$, Ta and $\mathrm{Pb}$ anomalies and negative $\mathrm{Sc}, \mathrm{Ti}, \mathrm{V}, \mathrm{Co}, \mathrm{Nb}, \mathrm{Ba}, \mathrm{La}$, Th and $\mathrm{Hf}$ anomalies. Ni displays a wide distribution.

5.1.4. Comparative Study between Capinha, Peroviseu-Seia, Belmonte-Covilhã and Fráguas Granites

A geochemical comparative study between CG and PS and BC and Fráguas granites from the FSEC region was carried out to delineate the possible evolutionary trend of the granites and to investigate their metallogenic potential. 
In the Fundão-Serra da Estrela-Capinha region, the Alpine orogeny triggered crustal uplift, thereby developing the "Serra da Estrela Horst" (SEH, currently 2000 m high). The construction of the SEH and subsequent erosion exposed deep structural levels to the surface.

The Fundão-Serra da Estrela-Capinha region consists of three distinct erosional levels according to their lithological and mineralization characteristics:

(1) The erosion level of the Serra da Estrela ( 2000 $\mathrm{m}$ above sea level), characterized by the occurrence of essentially granitic rocks; the metasedimentary rocks were completely eroded, so there is no evidence of ore deposits.

(2) The erosion level of Capinha (527 $\mathrm{m}$ above sea level), characterized by the occurrence of different granitic facies and low metamorphic metasedimentary rocks, whose contact is marked by hornfels; the occurrence of $\mathrm{W}$ and $\mathrm{W}(\mathrm{Sn})$ mineralizations is evident in the exo-contact between granites/metasediments and intragranitic;

(3) The erosion level of Fundão (depression at SW of SEH, $500 \mathrm{~m}$ above sea level) between Panasqueira and Argemela, characterized by the occurrence of essentially metasedimentary rocks with no outcropping of granitic rocks; W (Sn) occurrences are well preserved and hosted in the metasedimentary rocks, which are spatially associated with non-outcropping granitic rocks, e.g., Panasqueira. Exploration of the Panasqueira deposit in underground works showed the presence of a greisen cupola (1st evidence found in 1946), which is related to non-outcropping parental granite. A drilling campaign performed in 1953 cut greisenized granite at a $190 \mathrm{~m}$ depth (ca. $450 \mathrm{~m}$ above sea level), which is located at about $1550 \mathrm{~m}$ lower than the highest point of Serra da Estrela and at a similar height to the Capinha massif (527 $\mathrm{m}$ above sea level).

\section{Major and Trace Elements}

The major and trace element contents of the granites from the FSEC region are presented in Table 6. All the rocks have a granitic composition, with $\mathrm{SiO}_{2}$ values varying from $67.12 \mathrm{wt} \%$ to $74.13 \mathrm{wt} \%$; $\mathrm{TiO}_{2}$ values of $\sim 0.08 \mathrm{wt} \%-0.72 \mathrm{wt} \% ; \mathrm{Fe}_{2} \mathrm{O}_{3}{ }^{(\mathrm{Tot})}$ values of $\sim 1.14 \mathrm{wt} \%-4.08 \mathrm{wt} \%$, showing moderately high alkali contents; $\mathrm{Al}_{2} \mathrm{O}_{3}$ values of $\sim 14.04 \mathrm{wt} \%-15.76 \% ; \mathrm{Na}_{2} \mathrm{O}$ values of $\sim 2.49 \mathrm{wt} \%-3.47 \mathrm{wt} \%$; and $\mathrm{K}_{2} \mathrm{O}$ values of $\sim 4.26 \mathrm{wt} \%-5.27 \mathrm{wt} \%$, with low quantities of $\mathrm{CaO}(\sim 0.39 \mathrm{wt} \%-1.47 \mathrm{wt} \%)$ and $\mathrm{MgO}\left(\sim 0.17 \mathrm{wt}_{\mathrm{t}} \mathrm{-1.3} \mathrm{wt}_{\mathrm{t}} \%\right)$. Fráguas granite is the richest in $\mathrm{SiO}_{2}(73.36 \mathrm{wt} \%-74.13 \mathrm{wt} \%), \mathrm{BC}$ is the richest in $\mathrm{K}_{2} \mathrm{O}(5.04 \mathrm{wt} \%-5.12 \mathrm{wt} \%)$ and PS is the richest in $\mathrm{Fe}_{2} \mathrm{O}_{3}{ }^{\text {(Tot) }}(2.47 \mathrm{wt} \%-4.08 \mathrm{wt} \%)$. $\mathrm{TiO}_{2}$ decreases successively from PS-BC-Capinha-Fráguas. The $\mathrm{P}_{2} \mathrm{O}_{5}$ content is higher in Fráguas and Capinha granites.

The CG and BC are magnesian, and the PS and Fráguas are ferroan [102]. All the granites display associations with the high-K calc-alkaline affinity in the $\mathrm{K}_{2} \mathrm{O}$ versus $\mathrm{SiO}_{2}$ binary plot (Figure 8a). CG, BC and PS are peraluminous, with molecular A/CNK ratios ranging from 1.28 to $1.43,1.15$ to 1.32 and 1.17 to 1.36 , respectively. The Fráguas granite plots in the metaluminous field with A/CNK range from 0.92 to 1 (Figure $8 b$ ). 
Table 6. Major (wt\%) and trace element (ppm) data of Capinha were obtained in this study. The whole rock geochemical data of PS, BC and Fráguas were compiled from $[28,70,83]$. n.d.—not determined; LOI—lost on ignition; $\mathrm{n} —$ number of samples; Min—minimum; Max-maximum; $\bar{x}$-average; $\sigma$-standard deviation.

\begin{tabular}{|c|c|c|c|c|c|c|c|c|c|c|c|c|c|c|c|c|}
\hline \multirow{2}{*}{ Element } & \multicolumn{4}{|c|}{ Peroviseu-Seia $(n=5)$} & \multicolumn{4}{|c|}{ Belmonte-Covilhã $(n=3)$} & \multicolumn{4}{|c|}{ Fráguas $(n=3)$} & \multicolumn{4}{|c|}{ Capinha $(n=8)$} \\
\hline & Min & Max & $\bar{x}$ & $\sigma$ & Min & Max & $\bar{x}$ & $\sigma$ & Min & Max & $\bar{x}$ & $\sigma$ & Min & Max & $\bar{x}$ & $\sigma$ \\
\hline $\mathrm{SiO}_{2}$ & 67.12 & 72.4 & 70.06 & 1.81 & 71.14 & 73.31 & 72.13 & 0.9 & 73.36 & 74.13 & 73.68 & 0.33 & 72.07 & 73.41 & 72.76 & 0.42 \\
\hline $\mathrm{Al}_{2} \mathrm{O}_{3}$ & 14.04 & 15.76 & 14.9 & 0.63 & 14.29 & 14.86 & 14.65 & 0.25 & 14.34 & 14.89 & 14.64 & 0.23 & 14.33 & 15.1 & 14.8 & 0.24 \\
\hline $\mathrm{Fe}_{2} \mathrm{O}_{3}$ & 0.4 & 0.79 & 0.62 & 0.13 & 0.42 & 0.68 & 0.55 & 0.11 & 0.19 & 0.28 & 0.22 & 0.04 & 0.55 & 1.69 & 1.01 & 0.33 \\
\hline $\mathrm{MnO}$ & 0.04 & 0.05 & 0.05 & 0.005 & 0.03 & 0.04 & 0.04 & 0.005 & 0.05 & 0.07 & 0.06 & 0.01 & 0.03 & 0.05 & 0.04 & 0.01 \\
\hline $\mathrm{FeO}$ & 1.86 & 2.96 & 2.36 & 0.46 & 1.09 & 1.65 & 1.42 & 0.24 & 0.85 & 1.52 & 1.17 & 0.27 & 0.30 & 1.50 & 1.04 & 0.34 \\
\hline $\mathrm{MgO}$ & 0.48 & 1.3 & 0.77 & 0.3 & 0.3 & 0.65 & 0.45 & 0.15 & 0.17 & 0.22 & 0.19 & 0.02 & 0.41 & 0.67 & 0.52 & 0.09 \\
\hline $\mathrm{CaO}$ & 0.87 & 1.47 & 1.12 & 0.2 & 0.67 & 0.9 & 0.75 & 0.1 & 0.39 & 0.48 & 0.43 & 0.04 & 0.50 & 0.73 & 0.6 & 0.06 \\
\hline $\mathrm{Na}_{2} \mathrm{O}$ & 2.49 & 2.89 & 2.67 & 0.16 & 2.74 & 3.47 & 3.09 & 0.3 & 2.97 & 3.24 & 3.13 & 0.11 & 2.93 & 3.32 & 3.09 & 0.13 \\
\hline $\mathrm{K}_{2} \mathrm{O}$ & 4.84 & 5.27 & 5.05 & 0.16 & 5.04 & 5.12 & 5.09 & 0.03 & 4.42 & 4.73 & 4.6 & 0.13 & 4.26 & 4.5 & 4.4 & 0.09 \\
\hline $\mathrm{TiO}_{2}$ & 0.33 & 0.72 & 0.48 & 0.14 & 0.16 & 0.32 & 0.26 & 0.07 & 0.08 & 0.13 & 0.11 & 0.02 & 0.21 & 0.23 & 0.22 & 0.01 \\
\hline $\mathrm{P}_{2} \mathrm{O}_{5}$ & 0.2 & 0.36 & 0.29 & 0.06 & 0.22 & 0.29 & 0.26 & 0.03 & 0.28 & 0.4 & 0.34 & 0.05 & 0.33 & 0.38 & 0.36 & 0.01 \\
\hline $\mathrm{F}$ & 0.1 & 0.25 & 0.16 & 0.06 & 0.12 & 0.17 & 0.15 & 0.02 & 0.12 & 0.49 & 0.31 & 0.15 & n.d. & n.d. & n.d. & n.d. \\
\hline LOI & 0.98 & 2.18 & 1.36 & 0.45 & 0.93 & 1.46 & 1.11 & 0.25 & 1.06 & 1.21 & 1.12 & 0.07 & 0.98 & 1.56 & 1.22 & 0.18 \\
\hline Total & 99.73 & 99.99 & 99.87 & 0.1 & 99.73 & 100.05 & 99.94 & 0.15 & 99.87 & 100.14 & 100 & 0.11 & 98.75 & 100.74 & 100.06 & 0.61 \\
\hline $\mathrm{Nb}$ & 11 & 18 & 14.4 & 3.01 & 14 & 21 & 17 & 2.94 & 17 & 23 & 20.67 & 2.62 & 9 & 10 & 9.88 & 0.33 \\
\hline $\mathrm{Zn}$ & 48 & 66 & 59 & 7.25 & 62 & 71 & 66.5 & 4.5 & 35 & 71 & 53 & 18 & 50 & 90 & 62.5 & 11.99 \\
\hline Sn & 11 & 18 & 13.4 & 2.42 & 21 & 38 & 28 & 7.26 & 39 & 76 & 62 & 16.39 & 9 & 24 & 16.88 & 5.09 \\
\hline $\mathrm{Li}$ & 108 & 600 & 241.6 & 181.84 & 193 & 400 & 289.33 & 85.11 & 688 & 1100 & 829 & 191.68 & n.d. & n.d. & n.d. & n.d. \\
\hline $\mathrm{Zr}$ & 112 & 208 & 164.4 & 34.06 & 76 & 145 & 112.67 & 28.34 & 29 & 65 & 48.33 & 14.82 & 71 & 79 & 76.5 & 2.24 \\
\hline Y & 19 & 30 & 23.6 & 3.77 & 15 & 22 & 18 & 2.94 & 10 & 19 & 14.33 & 3.68 & 11 & 13 & 12.25 & 0.83 \\
\hline $\mathrm{Sr}$ & 66 & 152 & 96 & 35.2 & 51 & 60 & 55 & 3.74 & 21 & 33 & 27 & 4.9 & 61 & 74 & 67.38 & 4.58 \\
\hline $\mathrm{Ba}$ & 226 & 600 & 368.4 & 146.13 & 172 & 263 & 208.33 & 39.35 & 46 & 82 & 61.33 & 15.17 & 239 & 263 & 248.5 & 8.72 \\
\hline $\mathrm{Rb}$ & 228 & 299 & 274 & 26.1 & 190 & 351 & 290 & 71.28 & 465 & 607 & 523.33 & 60.68 & 239 & 268 & 252.5 & 8.26 \\
\hline Th & 12 & 27 & 18.25 & 6.14 & 12 & 13 & 12.5 & 0.5 & 7 & 7 & 7 & 0 & 6.3 & 7.2 & 6.73 & 0.27 \\
\hline $\mathrm{W}$ & n.d. & n.d. & 3 & n.d. & n.d. & n.d. & 3 & n.d. & n.d. & n.d. & 2 & n.d. & 6 & 12 & 9.63 & 1.93 \\
\hline $\mathrm{K} / \mathrm{Rb}$ & 136.88 & 182.42 & 154.38 & 15.19 & 119.21 & 222.84 & 157.08 & 46.68 & 63.73 & 84.45 & 73.96 & 8.46 & 131.96 & 149.02 & 144.73 & 5.15 \\
\hline $\mathrm{Fe}_{2} \mathrm{O}_{3}(\mathrm{Tot})$ & 2.47 & 4.08 & 3.24 & 0.62 & 1.63 & 2.38 & 2.13 & 0.35 & 1.14 & 1.88 & 1.53 & 0.31 & 2.02 & 2.25 & 2.17 & 0.07 \\
\hline $\mathrm{Rb} / \mathrm{Sr}$ & 1.5 & 4.53 & 3.27 & 1.16 & 3.52 & 6.88 & 5.29 & 1.38 & 18.39 & 22.14 & 19.66 & 1.76 & 3.41 & 4.15 & 3.76 & 0.25 \\
\hline $\mathrm{A} / \mathrm{CNK}$ & 1.17 & 1.36 & 1.26 & 0.07 & 1.15 & 1.32 & 1.23 & 0.07 & 0.92 & 1 & 0.96 & 0.03 & 1.28 & 1.43 & 1.35 & 0.04 \\
\hline $\mathrm{A} / \mathrm{NK}$ & 1.39 & 1.66 & 1.51 & 0.1 & 1.31 & 1.48 & 1.39 & 0.07 & 1.39 & 1.5 & 1.45 & 0.05 & 1.41 & 1.57 & 1.5 & 0.04 \\
\hline
\end{tabular}



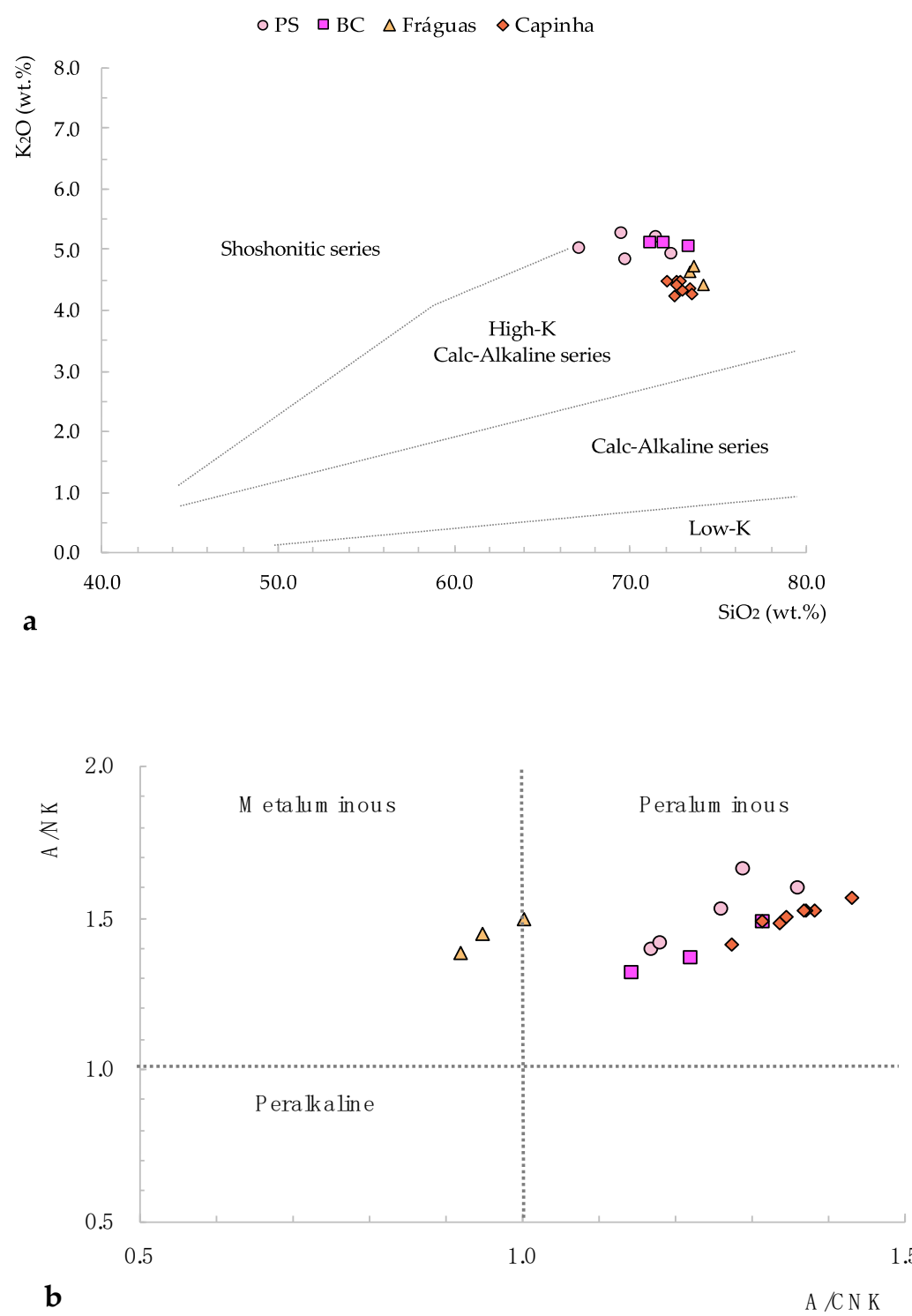

Figure 8. (a) $\mathrm{K}_{2} \mathrm{O}\left(\mathrm{wt} \%\right.$ ) versus $\mathrm{SiO}_{2}(\mathrm{wt} \%)$ plot showing the strong association between the granites from Fundão-Serra da Estrela-Capinha (FSEC) and the high-K calc-alkaline series; (b) A/NK versus A/CNK plot [105] displaying the aluminum saturation of the FSEC granites.

The $\mathrm{K} / \mathrm{Rb}$ ratio is a good indicator of magmatic differentiation [111], as $\mathrm{Rb}$ tends to concentrate in evolved residual melts due to its high incompatibility degree with the early formed mineral phases. Instead, $\mathrm{K}$ is included in the crystalline structures of alkali minerals and consequently decreases more quickly during magmatic differentiation. In response, the $\mathrm{K} / \mathrm{Rb}$ ratio decreases with an increase in magmatic differentiation ranging from 63.73 to 222.84. The variation diagrams for $\mathrm{SiO}_{2}, \mathrm{TiO}_{2}, \mathrm{Al}_{2} \mathrm{O}_{3}$, $\mathrm{Fe}_{2} \mathrm{O}_{3}{ }^{(\mathrm{Tot})}, \mathrm{CaO}, \mathrm{Na}_{2} \mathrm{O}, \mathrm{K}_{2} \mathrm{O}, \mathrm{P}_{2} \mathrm{O}_{5}, \mathrm{Ba}$ and $\mathrm{Sn}$ versus $\mathrm{K} / \mathrm{Rb}$ reveal that each granite experiences its own differentiation trend. However, the $\mathrm{CG}$ the samples are mostly clustered (Figure 9). The variation diagrams show that $\mathrm{TiO}_{2}, \mathrm{Fe}_{2} \mathrm{O}_{3}{ }^{(\mathrm{Tot})}, \mathrm{CaO}, \mathrm{K}_{2} \mathrm{O}$ and $\mathrm{Ba}$ decrease with a decrease in the $\mathrm{K} / \mathrm{Rb}$ ratio. On the other hand, the content of $\mathrm{SiO}_{2}, \mathrm{Al}_{2} \mathrm{O}_{3}, \mathrm{Na}_{2} \mathrm{O}, \mathrm{P}_{2} \mathrm{O}_{5}$ and $\mathrm{Sn}$ increases through magmatic differentiation. These variation diagrams also demonstrate that Fráguas granite is the most evolved facies, displaying $\mathrm{K} / \mathrm{Rb}$ ratios lower than 100 . 


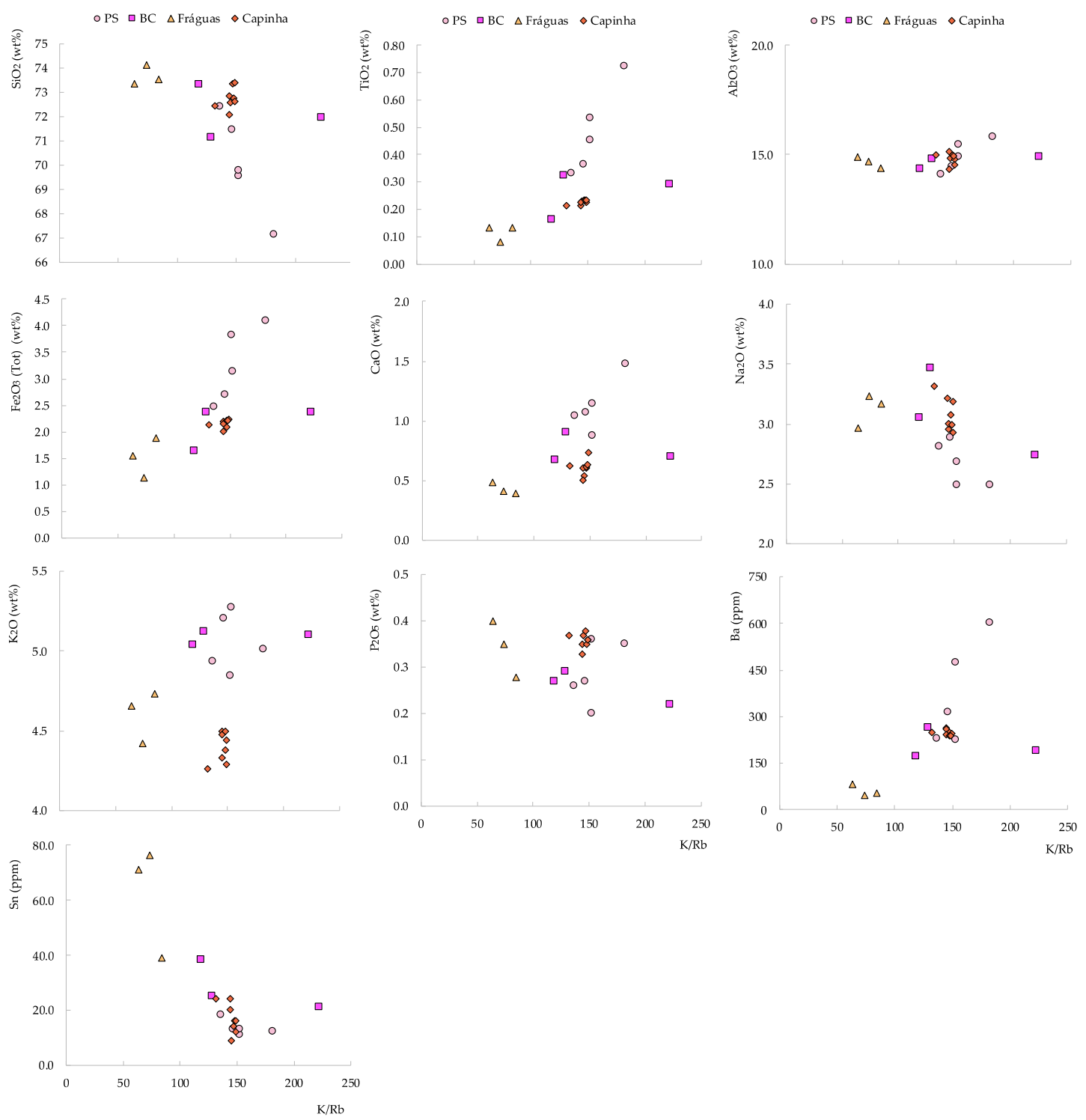

Figure 9. Variation diagrams showing major $\left(\mathrm{SiO}_{2}, \mathrm{TiO}_{2}, \mathrm{Al}_{2} \mathrm{O}_{3}, \mathrm{Fe}_{2} \mathrm{O}_{3}{ }^{(\mathrm{Tot})}, \mathrm{CaO}, \mathrm{Na}_{2} \mathrm{O}, \mathrm{K}_{2} \mathrm{O}\right.$ and $\mathrm{P}_{2} \mathrm{O}_{5}$ ) and trace element ( $\mathrm{Ba}$ and $\mathrm{Sn}$ ) distributions in the granites of the CG, Fráguas, BC and PS. The differentiation index $(\mathrm{K} / \mathrm{Rb})$ is used in all graphs. A decrease in $\mathrm{K} / \mathrm{Rb}$ represents an increase in magmatic fractionation.

$\mathrm{The} \mathrm{Rb} / \mathrm{Sr}$ ratio versus $\mathrm{Sn}$, as an indicator of the degree of magmatic differentiation, showed that the $\mathrm{Sn}$ increases with an increase in $\mathrm{Rb} / \mathrm{Sr}$ for the $\mathrm{Bc}$ and PS granites. On the other hand, the Fráguas and Capinha granites display constant $\mathrm{Rb} / \mathrm{Sr}$ values with an increase in $\mathrm{Sn}$ (Figure 10a). The Sr contents remained essentially unchanged and low $(<20)$.

The magmatic differentiation degree is also shown in the Rb-Sr-Ba ternary diagram [111], where most the granites are plotted in the strongly differentiated granite field. The high degree of differentiation of the Fráguas granite is supported by its high $\mathrm{SiO}_{2}$ contents; enrichment in incompatible elements such as $\mathrm{Li}, \mathrm{Rb}, \mathrm{Sn}$ and $\mathrm{Nb}$; and low quantities of $\mathrm{Ba}, \mathrm{Sr}, \mathrm{Zr}$ and $\mathrm{Y}$. The fractionation process continuously begins with the least differentiated facies, the PS and ends with the most evolved facies, Fráguas granite (Figure 10b). This fractionation is gradual and characterized by a quick decrease in $\mathrm{Ba}$, which replaces $\mathrm{K}$ in the structure of the $\mathrm{K}$ feldspar, while the $\mathrm{Rb}$ contents relatively increase their concentrations in the residual melts [28,112]. 

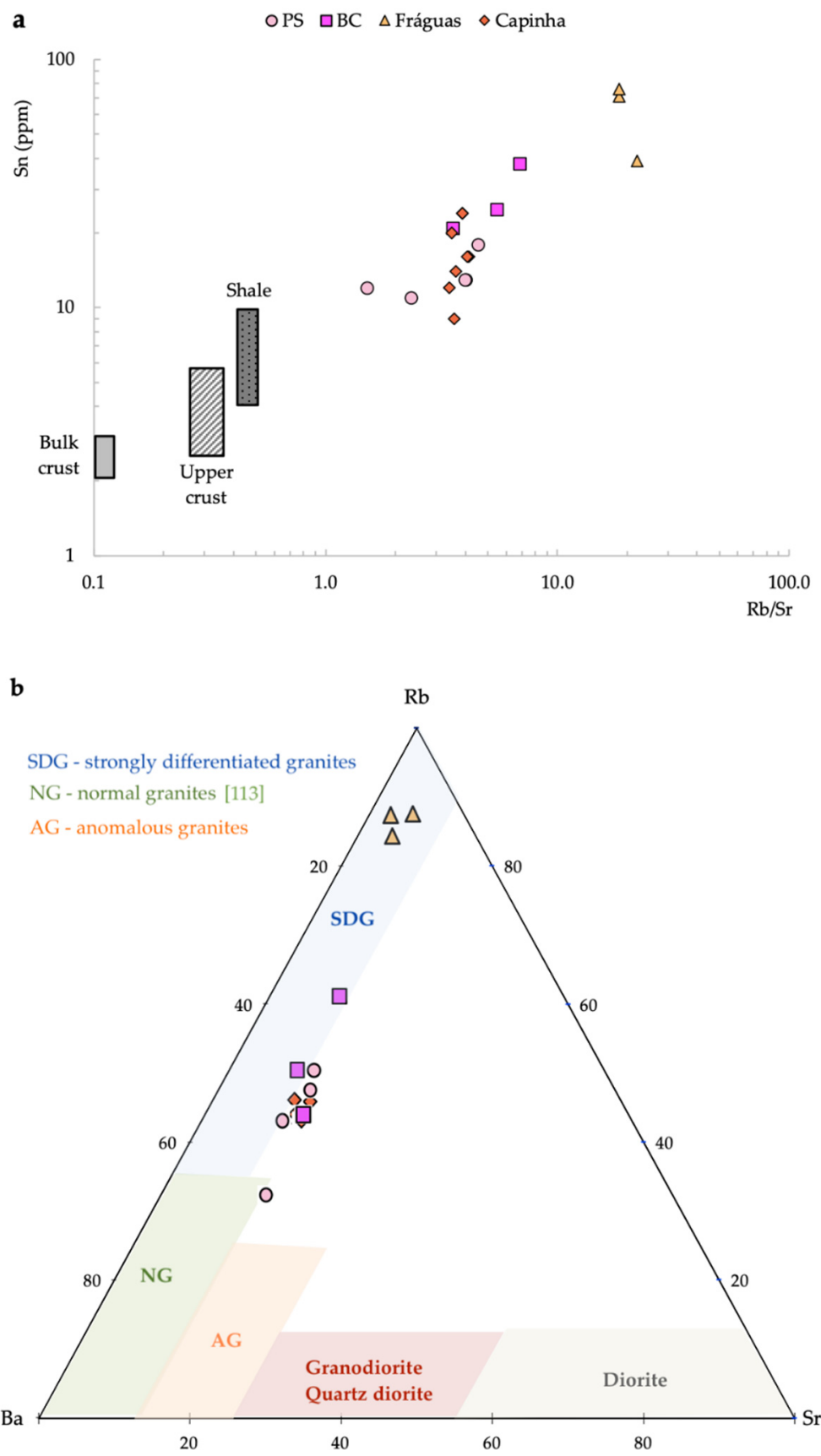

Figure 10. (a) Correlation of $\mathrm{Rb} / \mathrm{Sr}$ versus $\mathrm{Sn}$ for the granites in the study (logarithmic scale). The fields representative of bulk crust, upper crust and shale composition were taken from [28]; (b) $\mathrm{Rb}-\mathrm{Ba}-\mathrm{Sr}$ ternary diagram showing the evolution trend from the differentiation sequence between the diorite and strongly evolved granites [113] with the representation of the granites in the study clustered in the strongly differentiated granite field (blue field).

\section{Rare Earth Elements}

Table 7 presents rare earth element data of the studied granites. Chondrite-normalized REE patterns of the granites display very similar profiles, although the negative anomaly in $(\mathrm{Eu} / \mathrm{Eu})_{\mathrm{N}}$ is more pronounced in the Fráguas granite (Figure 11). The BC and PS profiles strongly overlap in the LREE (110.79 ppm and $113.3 \mathrm{ppm}$, respectively) compared to the HREE, where the PS is slightly enriched (14.2 ppm). The Capinha granite is more depleted in $\operatorname{REE}^{(\mathrm{Tot})}(74.67 \mathrm{ppm})$ than BC (REE ${ }^{(\mathrm{Tot})}$ $\sim 123.38 \mathrm{ppm}$ ) and PS (REE ${ }^{(\mathrm{Tot})} \sim 128.07 \mathrm{ppm}$ ), showing the most evolved REE pattern. The Capinha 
and Fráguas profiles are parallel in the LREE; however, Capinha is more impoverished in HREE than Fráguas, which is marked by a high REE fractionation with $(\mathrm{La} / \mathrm{Yb})_{\mathrm{N}}$ values of 10.34 and 7.19, respectively. The negative anomaly in $\mathrm{Eu}_{\mathrm{N}}$, related to the fractionation of feldspar, is more evident in the Fráguas granite $\left(\left(\mathrm{Eu} / \mathrm{Eu}^{*}\right)_{\mathrm{N}} \sim 0.09\right)$ compared to the other granites. Therefore, the CG exhibits the fewest marked negative anomalies in $\mathrm{Eu}_{\mathrm{N}}$ (typical of post-orogenic granites).

Table 7. Rare earth element (ppm) data for CG were obtained in this study. The whole rock geochemical data of PS, BC and Fráguas were compiled from [28,83,114]. The REE (rare earth elements) were normalized to chondrite according to [108]. n, number of samples; $\mathrm{REE}^{(\mathrm{Tot})}$, sum of all rare earth elements; $\operatorname{LREE}^{(\mathrm{Tot})}$, sum of all light rare earth elements; $\mathrm{HREE}^{(\mathrm{Tot})}$, some of all heavy rare earth elements; $\mathrm{N}$, normalized ratio.

\begin{tabular}{|c|c|c|c|c|}
\hline $\begin{array}{l}\text { Rare Earth } \\
\text { Element }\end{array}$ & $\begin{array}{l}\text { Peroviseu-Seia } \\
\quad \text { (PS) } n=5\end{array}$ & $\begin{array}{l}\text { Belmonte-Covilhã } \\
\text { (BC) } n=3\end{array}$ & Fráguas $n=3$ & Capinha $n=8$ \\
\hline $\mathrm{La}$ & 23.7 & 25.8 & 10.65 & 14.55 \\
\hline $\mathrm{Ce}$ & 53.8 & 50.7 & 24.4 & 30.86 \\
\hline $\operatorname{Pr}$ & 6.4 & 5.99 & 2.9 & 3.56 \\
\hline $\mathrm{Nd}$ & 24.2 & 23.7 & 10.8 & 13.63 \\
\hline $\mathrm{Sm}$ & 5.2 & 4.6 & 2.6 & 3.05 \\
\hline $\mathrm{Eu}$ & 0.57 & 0.65 & 0.15 & 0.5 \\
\hline $\mathrm{Gd}$ & 4.3 & 4.04 & 2.45 & 2.93 \\
\hline $\mathrm{Tb}$ & 0.73 & 0.6 & 0.42 & 0.44 \\
\hline Dy & 4.1 & 3.13 & 2.65 & 2.41 \\
\hline Ho & 0.77 & 0.68 & 0.45 & 0.41 \\
\hline Er & 1.9 & 1.54 & 1.15 & 1.09 \\
\hline $\mathrm{Tm}$ & 0.3 & 0.23 & 0.17 & 0.16 \\
\hline $\mathrm{Yb}$ & 11.8 & 1.5 & 1 & 0.955 \\
\hline $\mathrm{Lu}$ & 0.3 & 0.22 & 0.15 & 0.13 \\
\hline $\operatorname{LREE}^{(\mathrm{Tot})}$ & 113.3 & 110.79 & 51.35 & 65.65 \\
\hline $\operatorname{HREE}^{(\mathrm{Tot})}$ & 14.2 & 11.94 & 8.44 & 8.52 \\
\hline $\mathrm{REE}^{(\mathrm{Tot})}$ & 128.07 & 123.38 & 59.94 & 74.67 \\
\hline$(\mathrm{La} / \mathrm{Sm})_{\mathrm{N}}$ & 2.87 & 3.53 & 2.58 & 3.00 \\
\hline$(\mathrm{Gd} / \mathrm{Yb})_{\mathrm{N}}$ & 1.93 & 2.18 & 1.98 & 2.49 \\
\hline$(\mathrm{La} / \mathrm{Yb})_{\mathrm{N}}$ & 8.89 & 11.61 & 7.19 & 10.34 \\
\hline$\left(\mathrm{Eu} / \mathrm{Eu}^{*}\right)_{\mathrm{N}}$ or $\mathrm{Eu}_{\mathrm{N}}$ & 0.18 & 0.23 & 0.09 & 0.25 \\
\hline
\end{tabular}

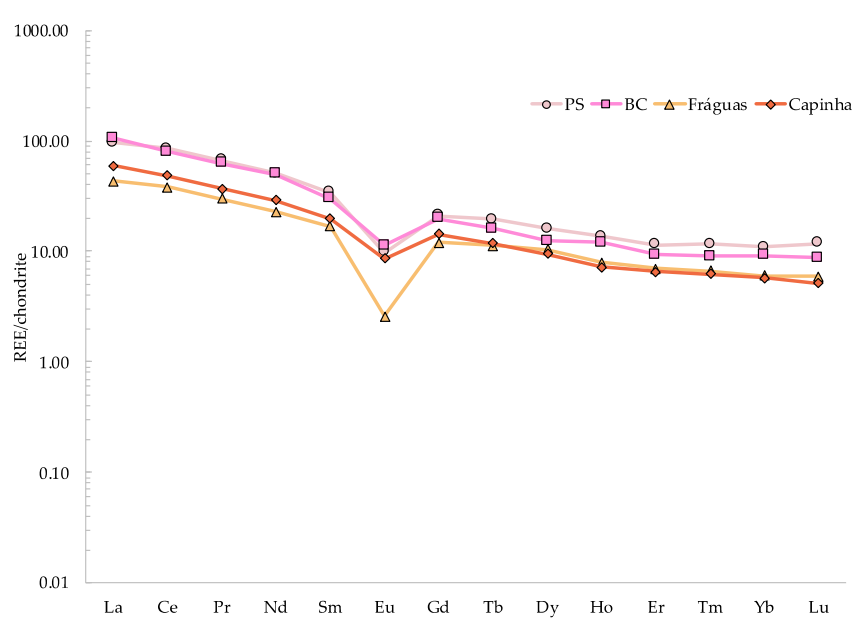

Figure 11. Rare earth element profiles for the PS, BC, CG and Fráguas granites (chondrite-normalized according to [109]. 
The REE patterns of PS and BC are subparallel. PS, moreover, is richer in all REE and has a lower $(\mathrm{La} / \mathrm{Yb})_{\mathrm{N}}$ ratio (8.89) than $\mathrm{BC}(11.61)$. The REE patterns of $\mathrm{BC}$ are similar to those of PS in Sm and $\mathrm{Gd}$, exhibiting a higher $\mathrm{Eu}_{\mathrm{N}}(0.23)$ value than PS (0.18) and suggesting that $\mathrm{BC}$ and PS are not related to each other. The CG, PS and BC are subparallel, where CG is poorer in REE (74.67 ppm) than BC (123.38 ppm) and PS (128.07 ppm). However, the CG flattened profile characterized by high Eu $\mathrm{u}_{\mathrm{N}}$ (0.25) indicates a distinct geological setting for its origin. The REE patterns of Fráguas and CG are subparallel in the LREE, whereas the REE spectra of Fráguas intercept those of CG in HREE, suggesting that Fráguas and CG are not related to each other. Considering these observations, the REE spectra suggest that PS, BC, CG and Fráguas are independent.

\subsection{Anisotropy of Magnetic Susceptibility}

The values of $K_{\mathrm{m}}, P_{\text {para }}, T$, the orientation of $K_{1}$ and $K_{3}$ and the $95 \%$ confidence angles (E12, E23, E31) of the $K_{1}, K_{2}, K_{3}$ axes of each sampling site are summarized in Table 8.

\subsubsection{Scalar Parameters}

Bulk Magnetic Susceptibility $\left(K_{\mathrm{m}}\right)$

The $K_{\mathrm{m}}$ magnitudes at each sampling site display a constrained range, covering one order of magnitude, which is typical of a paramagnetic contribution, ranging from 17.4 to $89.47 \mu$ S.I. (=73.4 $\mu$ S.I.) (Table 8). The spatial distribution of $K_{\mathrm{m}}$ in the whole granite (Figure 12a) showed a homogeneous zonation analogous to the statistical data, which show that $76.67 \%$ of the total measurements have a $K_{\mathrm{m}}$ higher than $70 \mu$ S.I. (see the frequency histogram Figure 12a). The lowest values are recorded in the eastern and western granite peripheries (sampling sites 17 and 8, respectively), which coincide with both the approximate axis of susceptibility symmetry and the granite long axis (NNE-SSW oriented). The highest values are concentrated in the northern zone. Although the granite is strongly homogeneous in its mineralogy and susceptibility, only a slight correlation between the granite mineralogy and susceptibility was observed. In zones where the amount of biotite is higher than muscovite, magnetic susceptibility increases. Since the biotite and muscovite are magmatic, magnetic susceptibility is strictly magmatic in origin. 
Table 8. AMS data for the 30 sampling sites in Capinha granite (CG). $n$, number of specimens, $K_{\mathrm{m}}$, bulk magnetic susceptibility expressed in $\mu$ S.I. (or $10^{-6}$ SI) units; $P_{\text {para }}$, magnitude of the paramagnetic anisotropy in $\% ; T$, shape parameter; $\sigma$, standard deviation; SE, standard error; $K_{1}, K_{3}$, orientation of average principal maximum, medium and minimum susceptibility axes (D, dip direction; I, dip); E12, E23, E31, eigenvalues [115], Min, minimum; Max, maximum; $\bar{x}$, average; n.d., not determined.

\begin{tabular}{|c|c|c|c|c|c|c|c|c|c|c|c|c|c|c|c|}
\hline \multirow[t]{2}{*}{ Site } & \multirow[t]{2}{*}{$n$} & \multirow[t]{2}{*}{$K_{\mathrm{m}}$} & \multirow[t]{2}{*}{$\sigma$} & \multirow[t]{2}{*}{$P_{\text {para }}$} & \multirow[t]{2}{*}{$T$} & \multirow[t]{2}{*}{$\sigma$} & \multicolumn{2}{|c|}{$\begin{array}{l}\text { Magnetic } \\
\text { Lineation }\end{array}$} & \multirow[t]{2}{*}{$K_{3} D$} & \multirow[t]{2}{*}{$K_{3} I$} & \multirow[t]{2}{*}{ Magnetic Foliation } & \multirow[t]{2}{*}{ E12 } & \multirow[t]{2}{*}{ E23 } & \multirow[t]{2}{*}{ E31 } & \multirow[t]{2}{*}{ SE } \\
\hline & & & & & & & $K_{1} D$ & $K_{1} I$ & & & & & & & \\
\hline 1 & 7 & 89.6 & 9.4 & 4.44 & -0.17 & 0.3 & 194 & 43 & 297 & 13 & $27^{\circ} \mathrm{NE} ; 77^{\circ} \mathrm{E}$ & 1.52 & 2.86 & 0.99 & 0.04 \\
\hline 2 & 7 & 79.9 & 4.71 & 1.39 & 0.11 & 0.52 & 139 & 35 & 272 & 45 & $\mathrm{~N} 2^{\circ} \mathrm{E} ; 45^{\circ} \mathrm{E}$ & 10.3 & 8.61 & 3.07 & 0.05 \\
\hline 3 & 12 & 72.1 & 5.42 & 1.6 & -0.04 & 0.15 & 302 & 10 & 190 & 65 & $\mathrm{~N} 280^{\circ} \mathrm{E} ; 25^{\circ} \mathrm{NE}$ & 7.24 & 7.36 & 3.88 & 0.06 \\
\hline 4 & 8 & 71 & 4.58 & 1.77 & 0.69 & 0.15 & 42 & 2 & 265 & 87 & $\mathrm{~N} 355^{\circ} \mathrm{E} ; 3^{\circ} \mathrm{E}$ & 18.94 & 3.68 & 3.1 & 0.06 \\
\hline 5 & 7 & 79.5 & 3.96 & 0.85 & -0.37 & 0.44 & 263 & 7 & 62 & 83 & $\mathrm{~N} 152^{\circ} \mathrm{E} ; 7^{\circ} \mathrm{SW}$ & 4.29 & 14.6 & 2.86 & 0.04 \\
\hline 6 & 8 & 80.9 & 5.82 & 1.89 & 0.07 & 0.21 & 201 & 15 & 68 & 69 & $\mathrm{~N} 158^{\circ} \mathrm{E} ; 21^{\circ} \mathrm{SW}$ & 6.7 & 5.79 & 3.26 & 0.06 \\
\hline 7 & 12 & 77.6 & 4.65 & 1.19 & 0.41 & 0.27 & 255 & 34 & 79 & 56 & $\mathrm{~N} 169^{\circ} \mathrm{E} ; 34^{\circ} \mathrm{SW}$ & 12.19 & 4.94 & 2.99 & 0.07 \\
\hline 8 & 7 & 17.4 & 0.88 & 0.61 & 0.47 & 0.21 & 53 & 11 & 259 & 78 & $\mathrm{~N} 349^{\circ} \mathrm{E} ; 12^{\circ} \mathrm{E}$ & 39.97 & 17.7 & 13.2 & 0.15 \\
\hline 9 & 9 & 76.6 & 3.93 & 2.31 & 0.55 & 0.3 & 190 & 33 & 336 & 52 & $\mathrm{~N} 66^{\circ} \mathrm{E} ; 38^{\circ} \mathrm{SE}$ & 8.04 & 2.22 & 1.59 & 0.04 \\
\hline 10 & 9 & 74.7 & 3.64 & 1.87 & 0.44 & 0.12 & 6 & 6 & 250 & 76 & $\mathrm{~N} 340^{\circ} \mathrm{E} ; 14^{\circ} \mathrm{NE}$ & 5.11 & 2.18 & 1.54 & 0.03 \\
\hline 11 & 8 & 69.2 & 2.98 & 1.43 & 0.47 & 0.46 & 262 & 19 & 129 & 63 & $\mathrm{~N} 219^{\circ} \mathrm{E} ; 27^{\circ} \mathrm{NW}$ & 21.98 & 8.84 & 4.61 & 0.08 \\
\hline 12 & 7 & 74.5 & 6.46 & 1.19 & 0.06 & 0.52 & 31 & 5 & 138 & 73 & $\mathrm{~N} 228^{\circ} \mathrm{E} ; 17^{\circ} \mathrm{NW}$ & 7.74 & 6.44 & 2.54 & 0.04 \\
\hline 13 & 6 & 75.1 & 8.15 & 1.27 & 0.36 & 0.26 & 209 & 4 & 15 & 86 & $\mathrm{~N} 105^{\circ} \mathrm{E} ; 4^{\circ} \mathrm{SW}$ & 9.78 & 4.92 & 3.25 & 0.04 \\
\hline 14 & 6 & 78.2 & 4.38 & 2.15 & 0.56 & 0.2 & 321 & 5 & 228 & 25 & $\mathrm{~N} 318^{\circ} \mathrm{E} ; 65^{\circ} \mathrm{NE}$ & 7.22 & 1.97 & 1.48 & 0.04 \\
\hline 15 & 9 & 76.9 & 2.78 & 1.71 & 0.33 & 0.39 & 189 & 3 & 66 & 85 & $\mathrm{~N} 156^{\circ} \mathrm{E} ; 5^{\circ} \mathrm{SW}$ & 14.98 & 7.17 & 4.81 & 0.08 \\
\hline 16 & 7 & 66.1 & 3.32 & 1.25 & 0.45 & 0.18 & 97 & 7 & 286 & 83 & $\mathrm{~N} 16^{\circ} \mathrm{E} ; 7^{\circ} \mathrm{SE}$ & 8.53 & 3.8 & 2.61 & 0.03 \\
\hline 17 & 6 & 61 & 3.2 & 0.65 & 0.04 & 0.66 & 68 & 14 & 330 & 28 & $\mathrm{~N} 60^{\circ} \mathrm{E} ; 62^{\circ} \mathrm{SE}$ & 9.58 & 11.1 & 2.83 & 0.05 \\
\hline 18 & 10 & 74.8 & 4.75 & 1.7 & 0.08 & 0.26 & 70 & 26 & 217 & 59 & $\mathrm{~N} 307^{\circ} \mathrm{E} ; 31^{\circ} \mathrm{NE}$ & 6.53 & 5.7 & 2.91 & 0.05 \\
\hline 19 & 6 & 87.9 & 3.86 & 2.18 & -0.33 & 0.24 & 156 & 38 & 281 & 36 & $\mathrm{~N} 11^{\circ} \mathrm{E} ; 54^{\circ} \mathrm{SE}$ & 3.13 & 7.22 & 2.08 & 0.05 \\
\hline 20 & 9 & 76.2 & 4.2 & 1.36 & 0.5 & 0.23 & 167 & 13 & 33 & 71 & $\mathrm{~N} 123^{\circ} \mathrm{E} ; 19^{\circ} \mathrm{SW}$ & 11.47 & 3.04 & 2.2 & 0.03 \\
\hline 21 & 8 & 66.4 & 4.47 & 2.79 & 0.53 & 0.26 & 64 & 8 & 256 & 82 & $\mathrm{~N} 166^{\circ} \mathrm{E} ; 8^{\circ} \mathrm{NE}$ & 9.81 & 2.6 & 2.05 & 0.05 \\
\hline 22 & 9 & 78.7 & 7.59 & 2.53 & 0.67 & 0.16 & 185 & 1 & 87 & 82 & $\mathrm{~N} 177^{\circ} \mathrm{E} ; 8^{\circ} \mathrm{W}$ & 8.44 & 1.42 & 1.18 & 0.03 \\
\hline 23 & 8 & 72.5 & 3.04 & 1.65 & 0.29 & 0.2 & 246 & 8 & 353 & 64 & $\mathrm{~N} 83^{\circ} \mathrm{E} ; 26^{\circ} \mathrm{SE}$ & 6.31 & 3.1 & 2.03 & 0.03 \\
\hline 24 & 7 & 73.4 & 2.06 & 1.89 & 0.53 & 0.2 & 314 & 1 & 45 & 36 & $\mathrm{~N} 135^{\circ} \mathrm{E} ; 54^{\circ} \mathrm{SW}$ & 12.64 & 3.67 & 2.87 & 0.05 \\
\hline 25 & 5 & 64.5 & 3.67 & 2.32 & 0.47 & 0.15 & 243 & 4 & 139 & 77 & $\mathrm{~N} 49^{\circ} \mathrm{E} ; 13^{\circ} \mathrm{NW}$ & 6.56 & 3.12 & 1.74 & 0.04 \\
\hline 26 & 6 & 79.5 & 9.76 & 2.1 & 0.18 & 0.17 & 196 & 6 & 97 & 55 & $\mathrm{~N}^{\circ} \mathrm{E} ; 35^{\circ} \mathrm{NW}$ & 3.45 & 2.6 & 1.47 & 0.03 \\
\hline 27 & 6 & 89.7 & 30.7 & 2.22 & 0.46 & 0.27 & 171 & 24 & 316 & 62 & $\mathrm{~N} 226^{\circ} \mathrm{E} ; 28^{\circ} \mathrm{SE}$ & 5.2 & 1.5 & 1.02 & 0.02 \\
\hline 28 & 6 & 75 & 6.74 & 2.64 & -0.23 & 0.26 & 12 & 20 & 140 & 60 & $\mathrm{~N} 50^{\circ} \mathrm{E} ; 30^{\circ} \mathrm{NW}$ & 4.1 & 11.6 & 2.82 & 0.07 \\
\hline 29 & 6 & 69.7 & 5.39 & 1.78 & 0.27 & 0.6 & 193 & 13 & 296 & 45 & $\mathrm{~N} 206^{\circ} \mathrm{E} ; 45^{\circ} \mathrm{SE}$ & 22.13 & 10.4 & 4.67 & 0.08 \\
\hline \multirow[t]{5}{*}{30} & 6 & 73.3 & 4.95 & 8.04 & 0.42 & 0.09 & 199 & 5 & 21 & 85 & $\mathrm{~N} 111^{\circ} \mathrm{E} ; 5^{\circ} \mathrm{SW}$ & 6.1 & 2.75 & 1.93 & 0.09 \\
\hline & & 17.4 & 0.88 & 0.61 & -0.37 & 0.09 & & & & & & 1.52 & 1.42 & 0.99 & 0.02 \\
\hline & & 89.67 & 30.7 & 8.04 & 0.69 & 0.66 & & & & n.d. & & 39.97 & 17.7 & 13.2 & 0.15 \\
\hline & & 12.29 & 5.06 & 1.33 & 0.29 & 0.14 & & & & & & 7.48 & 3.99 & 2.16 & 0.03 \\
\hline & & 73.4 & 5.65 & 2 & 0.3 & 0.28 & 166 & 5 & 328 & 85 & $\mathrm{~N} 58^{\circ} \mathrm{E} ; 5^{\circ} \mathrm{SE}$ & 10 & 5.8 & 2.9 & 0.05 \\
\hline
\end{tabular}



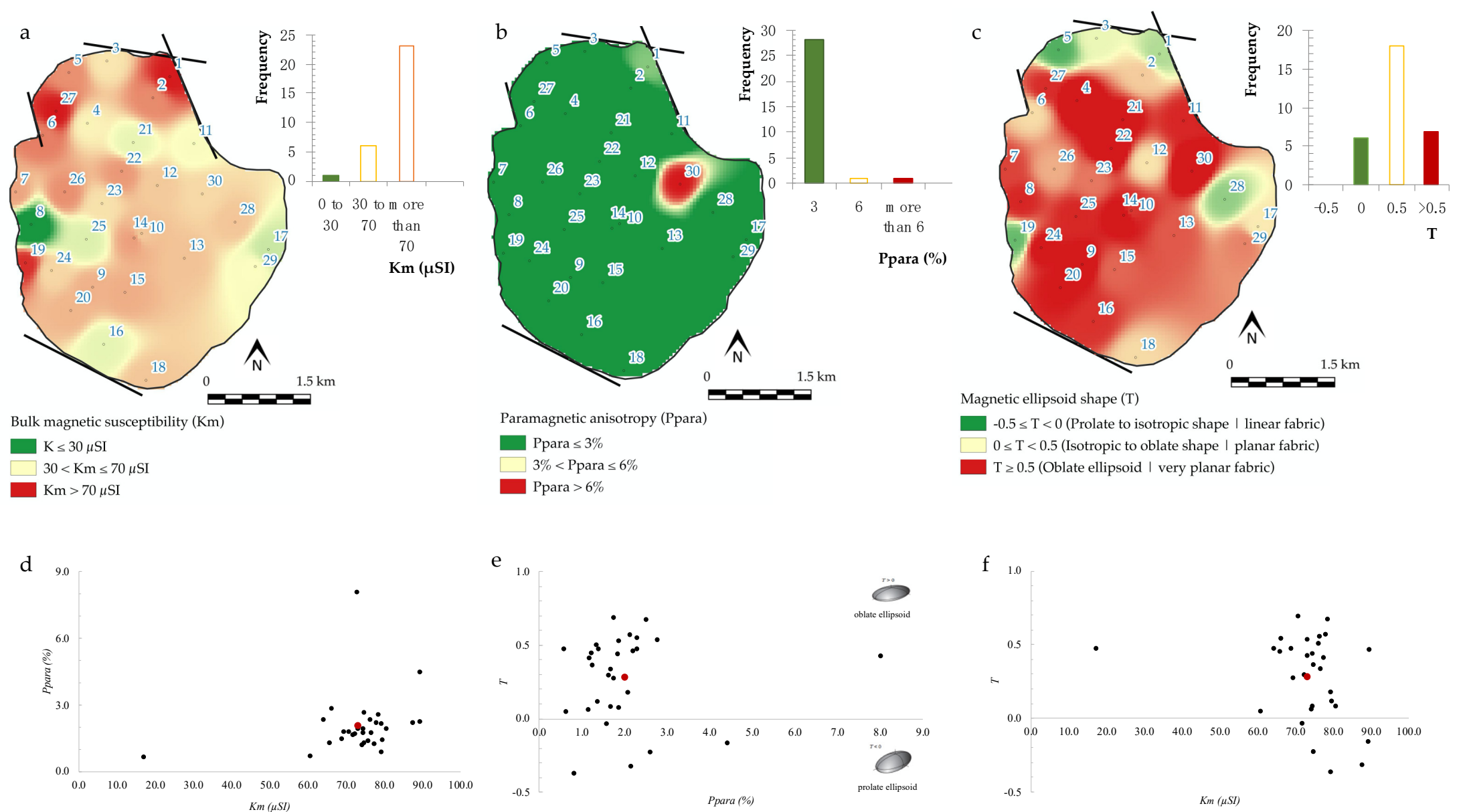

$-0.5 \leq \mathrm{T}<0($ ritate to isotic

Figure 12. Domain and frequency distribution of (a) bulk magnetic susceptibility $\left(K_{\mathrm{m}}, \mu \mathrm{S} . \mathrm{I}.\right),(\mathbf{b})$ paramagnetic anisotropy percentage $\left(P_{\text {para }}, \%\right)$ and $(\mathbf{c})$ the magnetic ellipsoid shape parameter $(T)$ in Capinha granite. The relationship between the three scalar parameters obtained in AMS studies, namely, (d) $K_{\mathrm{m}}$ versus $P_{\text {para }}$ (e) $P_{\text {para }}$ versus $T$ and (f) $K_{\mathrm{m}}$ versus $T$ are also presented. Note: the red circle represents the average. 
Paramagnetic Anisotropy $\left(P_{\text {para }}\right)$

The percentage of $P_{\text {para }}$ within the granite ranges from $0.61 \%$ to $8.04 \%$ (Figure $12 \mathrm{~b}$ ). However, the frequency distribution shows that only $6.66 \%$ of the total measurements display a $P_{\text {para }}$ higher than $3 \%$ (see the frequency histogram Figure 12b), demonstrating that $P_{\text {para }}$ is relatively homogeneous at the intrusion scale. The highest values are located in the peripheries (at sampling sites 1 and 30), reflecting the low-temperature solid state deformation experienced by the granite during magma solidification. The average value is $2.0 \%$ for the magmatic to submagmatic deformation. The charts in Figure 12d,e show the directly proportional relationship between $K_{\mathrm{m}}$ versus $P_{\text {para }}$ and $P_{\text {para }}$ versus $T$.

Magnetic Ellipsoid Shape Parameter ( $T$ )

The $T$ value varies between -0.37 to 0.69 , but most the ellipsoids are plotted within the flattening field $(0<T<1$, planar fabric) (Figure 12c). The sites plotted within the prolate field $(T<0)$ are located mainly in high magnetic susceptibility sites (Figure 12a,c). This relation is also observable in the $K_{\mathrm{m}}$ versus $T$ chart presented in Figure 12f, where the locations with the highest $K_{\mathrm{m}}$ display prolate shapes. The spatial distribution of $T$ (Figure 12c) shows a symmetrical pattern, with an NNE-SSW axis of symmetry that coincides with the pluton long axis, similar to the $K_{\mathrm{m}}$ spatial distribution.

\subsubsection{Directional Magnetic Parameters}

Based on the interpretation of the magnetic fabric, the orientation of the magnetic foliation is variable, ranging from NNW-SSE to NNE-SSW (Figure 13a $a_{1}$ ). Generally, the magnetic foliations are sub-horizontal, featuring more vertical dips in the granite borders-mainly in the northeastern near the intersection of the ESE-WNW and the NNW-SSE fractures. The magnetic foliation arrangement displays concentric trajectories defining an elongated gently outward-dipping tongue shape with symmetry trending roughly NE-SW (Figure $13 \mathrm{a}_{2}$ ). The orientation of the average magnetic foliation is $\mathrm{N} 58^{\circ} \mathrm{E} ; 5^{\circ} \mathrm{SE}$ (see the stereogram presented in Figure 13a $\mathrm{a}_{1}$ ), which in turn lies subparallel to the symmetry axis of the magnetic trajectories (Figure $13 \mathrm{a}_{1}, \mathrm{a}_{2}$ ). The scattering of magnetic lineations within the granite is characterized sub-horizontally along the NNE-SSW direction parallel to the granite's major axis; however, in the south-eastern border, the lineations tend to be parallel to the point of contact (Figure 13 $\mathbf{b}_{1}$ ). The magnetic lineation arrangement defines elongated trajectories (Figure 13 $\mathbf{b}_{2}$ ) with a symmetry axis concordant with the orientation of the average of magnetic lineation, which is $5^{\circ} / \mathrm{N} 196^{\circ} \mathrm{E}$ (see the stereogram represented in Figure $13 \mathrm{~b}_{1}$ ). 

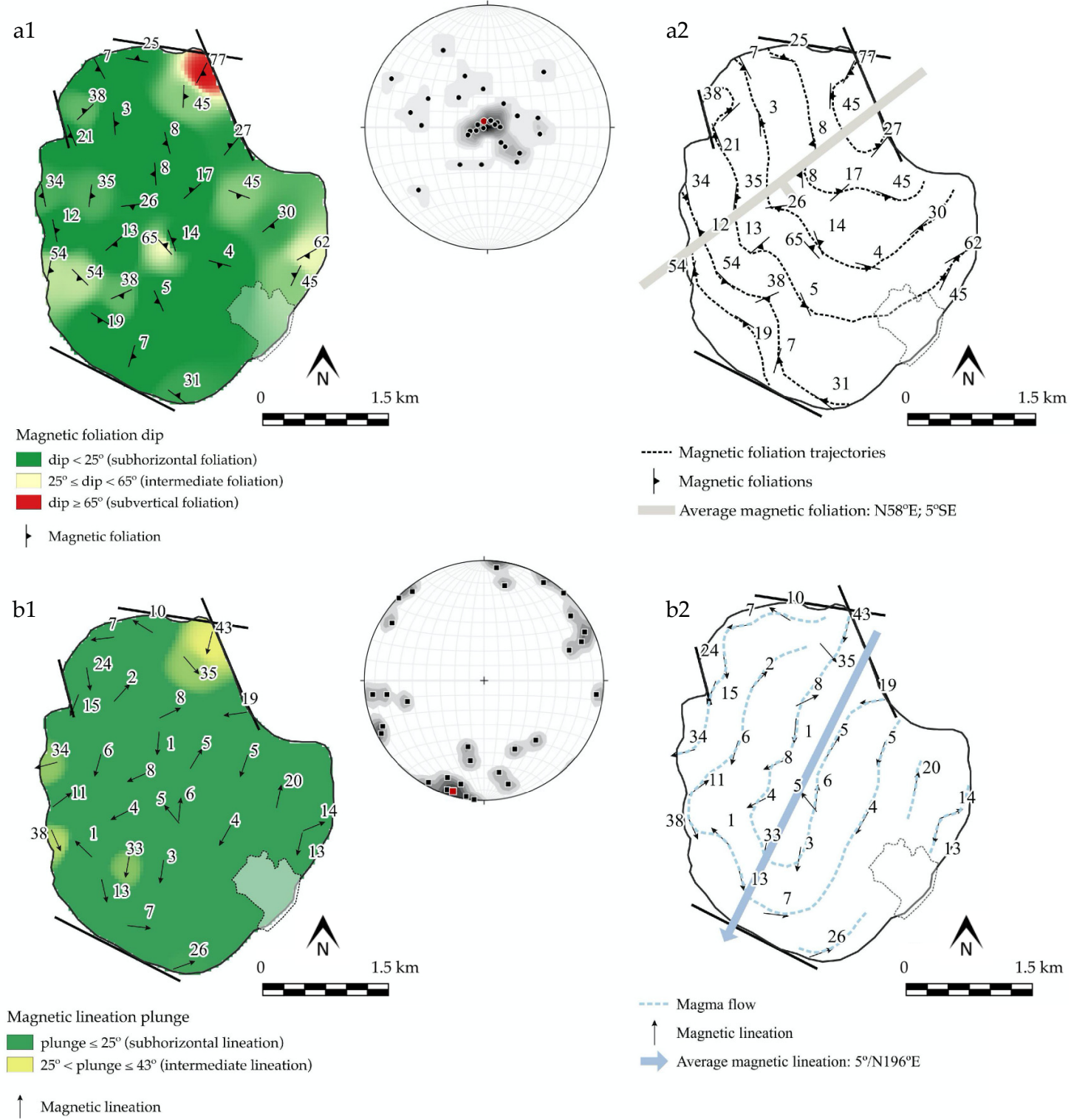

Figure 13. Magnetic foliation (perpendicular to $\left.K_{3}\right)$ and lineation $\left(K_{1}\right)$ within the Capinha granite. Stereograms: equal-area, lower-hemisphere projection and contour intervals with uniform distribution; (a1) dip direction and dip of magnetic foliation at individual sampling sites. Stereogram of magnetic foliation poles. Inset map: variation in the dip angle of magnetic foliation; (a2) interpretative form-line map (magnetic trajectories) of magnetic foliations; (b1) plunge and azimuth of magnetic lineation at individual sampling sites. Stereogram of lineation orientations. Inset map: variation in the plunge angle of magnetic lineation; (b2) Interpretative magma flow based on magnetic lineations.

\subsection{Fracturing}

\subsubsection{Outcrop Fracturing}

The measurement of the outcrop fracturing in CG was made in situ in two distinct quarries using photo-interpreted faults, obtaining a total of 54 measurements. In general, the Capinha granite is moderated fractured. The main orientations obtained in the quarries are consistent with the photo-interpreted faults. The statistical study showed four representative fracture systems, $40^{\circ} \mathrm{NE}-50^{\circ}$ $\mathrm{NE}(14.81 \%), 30^{\circ} \mathrm{NE}-\mathrm{N} 40^{\circ} \mathrm{NE}(11.11 \%), 20^{\circ} \mathrm{NE}-\mathrm{N} 30^{\circ} \mathrm{NE}(9.26 \%)$ and $0^{\circ} \mathrm{NE}-10^{\circ} \mathrm{NE}(11.11 \%)$, corresponding to $46.29 \%$ of the total measurements (Figure 14 ). 

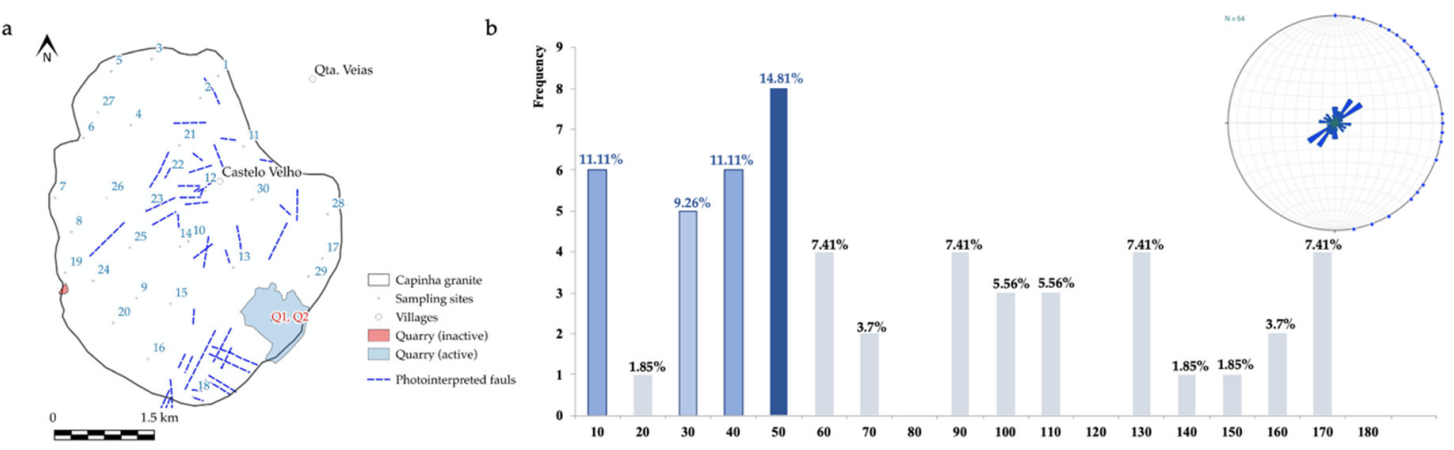

Figure 14. Outcropping scale fracturing in CGe. (a) Mapping of the photo-interpreted and regional fracturing systems visible in the CG; (b) histogram representing the distribution of the outcrop fracturing according to the $10^{\circ}$ class subdivision and its corresponding rose diagram. Dark blue highlights the most important classes of the fracturing preferential orientations.

\subsubsection{Microfracturing}

The measurements of mode I microfractures in quartz (extensional or opening cracks, according to $[116,117])$ at a microscopic scale were used to better understand the evolution of regional stress. These cracks defined by "fluid inclusion planes" (FIP) were used as the markers of brittle deformation, as these sealed cracks do not affect mechanical continuity through the quartz crystal. The FIP appear aligned independent of the crystallographic orientation of the quartz crystals and cross-cutting quartz boundaries.

Microfracturing was studied in 8 thin sections and 118 microfractures were measured. The study and measurement of these microfractures showed that the granite did not exhibit strong brittle deformation at a microscopic scale. The statistical analysis showed a preferential orientation constrained into four systems: $40^{\circ} \mathrm{N}-50^{\circ} \mathrm{E}(16.24 \%), 50^{\circ} \mathrm{N}-60^{\circ} \mathrm{E}(11.11 \%), 60^{\circ} \mathrm{N}-70^{\circ} \mathrm{E}(10.26 \%)$ and $70^{\circ} \mathrm{N}-80^{\circ} \mathrm{E}$ (9.4\%), representing $47.01 \%$ of the total measurements (Figure 15 ).
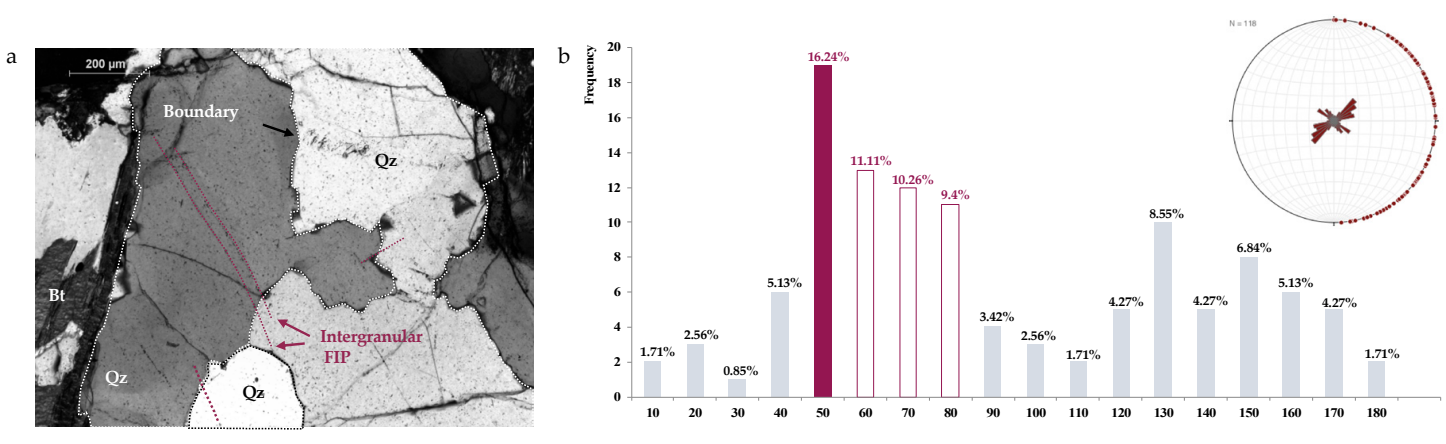

Figure 15. Statistical data obtained from the FIP measurements. (a) Microphotograph showing the general aspects of the intergranular FIP measured in quartz from the CG; (b) histogram representing the distribution of the FIP orientation according to the $10^{\circ}$ class subdivisions and the corresponding rose diagram. Magenta indicates the most important classes of the FIP's preferential orientations.

\section{Discussion}

A combination of several approaches showed that the FSEC region is composed of a complex set of granitic facies intruding the metasedimentary sequences. The study on the magnetic parameters $\left(K_{\mathrm{m}}, P_{\mathrm{para}}, T\right.$ and magnetic fabric) and geochemical signatures led to a more complete characterization of Capinha granite, helping us understand its spatial and genetic relationship with the host granites and evaluate its metallogenic potential. 


\subsection{Sequence of Magmatic Episodes}

Capinha granite is peraluminous (molar A/CNK 1.35), muscovite-rich, relatively rich in potassium (ca. $4.4 \mathrm{wt} \%$ ) and has high silica content (72.07 wt\% to $73.41 \mathrm{wt} \%$ ). PS and BC display similar characteristics but represent two independent episodes (PS is the older one). Fráguas granite is younger than BC granite and displays a metaluminous character (A/CNK 0.96) (Figure 8b). Capinha and Fráguas represent independent and distinct magma pulses from PS and BC biotite-rich granites (Figures 9, 10b and 11).

The geochemical signatures of PS, BC, Fráguas and CG were compared to the melts produced by the experimental dehydration-melting of several distinct metasediments proposed in [118]. PS, BC and Fráguas could have formed by the partial melting of mafic pelites and greywackes [28] and Capinha granite (Tables 4 and 6) could have resulted from the partial melting of sources dominated by protholiths enriched in K feldspar [102,119,120], which is evidenced by their high-K calc-alkalic association (Figure 8a), low Ba and $\mathrm{Sr}$ and negative anomalies in $\mathrm{Eu}_{\mathrm{N}}$ (Figures 9 and 11).

The whole rock variation diagrams for major and trace elements (Figure 9) illustrate four distinct differentiation trends for the FSEC granites (PS, BC, Capinha and Fráguas), where the least evolved granite is PS and the most evolved is Fráguas, which is also supported by the Rb-Ba-Se ternary diagram (Figure 10b). The distinct and independent trends drawn by PS and BC are also supported by the REE diagrams, where the PS and BC displayed parallel REE profiles, with PS enriched in $\operatorname{REE}^{(\mathrm{Tot})}$. The isotopic data obtained in [28] support the hypothesis of distinct source magmas for PS and BC, which present an $\varepsilon \mathrm{Nd}$ of -3.9 and -3.7 and a $\left({ }^{87} \mathrm{Sr} /{ }^{86} \mathrm{Sr}\right)_{300}$ ratio of 0.7081 and 0.7076 , respectively. The Fráguas and Capinha granites are neither related to each other nor to PS and BC, which is confirmed by the intersection of the REE patterns of Fráguas and Capinha in HREE. The Fráguas granite displays the highest negative anomaly, which suggests that this granite is more strongly enriched in plagioclase than the others. Although the Capinha REE pattern is parallel to the patterns of PS and BC REE, the $(\mathrm{Eu} / \mathrm{Eu})_{\mathrm{N}}$ negative anomaly is less marked, demonstrating a slight flattened REE profile, which is typical of granites emplaced in post-orogenic settings.

\subsection{Interpretation of the Scalar Magnetic Parameters of Capinha Granite}

Table 9 summarizes all the results obtained in the fieldwork, petrography, microfracturing and AMS approaches.

The $K_{\mathrm{m}}$ in Capinha granite is, in general, homogeneous and does not display petrographic zonation. The abundance of muscovite compared to biotite is evident in the magnetic susceptibility, which is lower than $89.67 \mu$ S.I., a feature typical of muscovite $>$ biotite ilmenite-type Portuguese Variscan granites ([121] and the references therein). The lowest values of $K_{\mathrm{m}}(<30 \mu$ S.I.) are characterized by an enrichment of $\mathrm{K}$ feldspar crystals, which only occur on one site located in the western contact between the Capinha and BC granites.

The microstructural study in the CG displayed the predominance of magmatic to submagmatic microstructures corresponding to a $P_{\text {para }}$ of about $2.0 \%$. However, a continuous transition was observed from magmatic to submagmatic microstructures in the core to low-T solid state microstructures in the peripheries. The low-T post-magmatic state is, essentially, characterized by a strong sericitization of the Na-plagioclase and by the occurrence of sutured borders and fracturing of quartz crystals (Figure 4 and Table 3). The highest $P_{\text {para }}$ values are only correlated to microdeformation since at the meso- and macroscale, the intrusion does not exhibit deformation. The evidence of low values for $P_{\text {para }}$ and the absence of deformation to the naked eye may indicate that the magnetic directional fabric observed in the Capinha granite was acquired during the magma ascent and emplacement.

The Fe-bearing silicate mineral (i.e., biotite) is responsible for the magnetic susceptibility magnitude and also for the ellipsoid magnetic shape $(T)$. The spatial distribution of $T$ in the granite displays an oblate shape, indicating a planar fabric, which is concordant with the lamellar shape of the biotite. However, linear fabrics are represented in the peripheries of the pluton. Considering that the present topography exposes the roof of the granitic suit based on sub-horizontal magnetic lineations and 
foliations, a planar shape may be related to flattening against the overlying rocks before the erosion processes. The zones where the $T$ shows prolate shapes and linear fabrics may indicate the granite feeder zone locations.

Table 9. Summary of the data obtained from the study of Capinha granite.

\begin{tabular}{|c|c|}
\hline Feature & Description \\
\hline \multicolumn{2}{|r|}{ Fieldwork } \\
\hline Altitude (min, $\max )$ & $461,670 \mathrm{~m}$ \\
\hline Outcrop shape & Circular circumscribed body \\
\hline Outcrop area & $7 \mathrm{~km}^{2}$ \\
\hline Relationship with surrounding rocks & Sharp contact between the granite and the surrounding rocks \\
\hline Grain size & Medium-grained \\
\hline Texture & Slightly porphyritic (K feldspar megacrysts $\sim 1 \mathrm{~cm}$ ) \\
\hline Enclaves & No enclaves were observed \\
\hline Fracturing & $\begin{array}{l}\text { Moderately fractured: } 40^{\circ} \mathrm{N}-50^{\circ} \mathrm{E}, 30^{\circ} \mathrm{N}-40^{\circ} \mathrm{E}, 20^{\circ} \mathrm{N}-30^{\circ} \mathrm{E} \\
\text { and } 0^{\circ} \mathrm{N}-10^{\circ} \mathrm{E} \text {, corresponding to } 46.29 \%\end{array}$ \\
\hline Deformation patterns & No deformation patterns were observed, except for the fracturing \\
\hline \multicolumn{2}{|r|}{ Petrography } \\
\hline Main mineralogy & $\begin{array}{c}\text { Quartz }(\sim 40 \%), \mathrm{K} \text { feldspar }(\sim 25 \%) \text { and Na plagioclase (albite and } \\
\text { albite-oligoclase, } \sim 20 \%)\end{array}$ \\
\hline Accessory mineralogy & $\begin{array}{c}\text { Muscovite, biotite, chlorite, apatite, rutile, zircon, monazite and } \\
\text { opaque mineralogy }(\sim 15 \%)\end{array}$ \\
\hline Opaque mineralogy & Ilmenite, hematite, arsenopyrite and pyrite \\
\hline Later alterations & $\begin{array}{c}\text { Sericitization of Na plagioclase, chloritization, the } \\
\text { muscovitization of biotite and the oxidation of Fe-bearing } \\
\text { minerals }\end{array}$ \\
\hline Microstructures & $\begin{array}{l}\text { Essentially magmatic to submagmatic with low-T solid stage } \\
\text { microstructures }\end{array}$ \\
\hline \multicolumn{2}{|r|}{ Microfracturing } \\
\hline Fluid inclusion planes & $40^{\circ} \mathrm{N}-50^{\circ} \mathrm{E}, 50^{\circ} \mathrm{N}-60^{\circ} \mathrm{E}, 60^{\circ} \mathrm{N}-70^{\circ} \mathrm{E}, 70^{\circ} \mathrm{N}-80^{\circ} \mathrm{E}$ \\
\hline Absolute frequency & $16.24 \%, 11.11 \%, 10.26 \%$ and $9.4 \%$, respectively \\
\hline \multicolumn{2}{|c|}{ Anisotropy of magnetic susceptibility } \\
\hline Magnetic susceptibility $\left(K_{\mathrm{m}}\right)$ & $73.4 \mu$ S.I. \\
\hline Paramagnetic anisotropy $\left(P_{\text {para }}\right)$ & $2.0 \%$ \\
\hline Magnetic ellipsoid shape $(T)$ & 0.3 \\
\hline Magnetic foliation & $58^{\circ} \mathrm{NE} ; 5^{\circ} \mathrm{SE}$ \\
\hline Magnetic lineation & $5^{\circ} / 196^{\circ} \mathrm{N}$ \\
\hline
\end{tabular}

\subsection{Magnetic/Magmatic Fabric in Capinha: Shape and Possible Feeder Zone}

The evidence of consistently low values of $P_{\text {para }}$ in the whole Capinha granite and the absence of significative deformation patterns at distinct scales suggest that the spatial distribution and behavior of the magnetic fabric reflects the magmatic flow acquired during the ascent and emplacement of the Capinha magma.

The map of magnetic foliation trajectories (Figure 13a2), obtained by simple extrapolation of the foliation traces at each site, clearly identifies an NE-SW elongated tongue-shape dome, whose core is located in the north-eastern boundary, where the dips are strong. Generally, in the western boundaries, the foliations display outward dips, which suggest continuity of the body under the PS granite. However, in the north-eastern boundary, foliations dip inward, corresponding to the close of the suite.

The orientation of the Fe-bearing minerals' major axis (mainly biotite), which corresponds to the magnetic lineations, may provide important information about the magma flow. In general, the lineations are sub-horizontal with NNE-SSW striking, which agrees with the major axes of the granite body. The spatial arrangement of the lineations describe an SSW magma flow (Figure 13b 2 ) with a presumed feeder zone in the north-eastern zone, where the lineation and foliation are vertical. The occurrence of overall sub-horizontal lineations suggests increases in horizontal movement that are higher than the vertical ones, indicating that the outcrop surface is the roof of the intrusion. 
Considering these observations, we propose the presence of a possible feeder zone in the north-eastern boundary, where the foliations and lineations display vertical dips, $P_{\text {para }}$ exhibits higher values and the magnetic ellipsoid shape illustrates linear fabrics.

\subsection{Integration of the Capinha Magnetic/Magmatic Fabric in Previous Studies}

Previous studies performed in Serra da Estrela [122] that applied AMS and microstructural methods revealed that the emplacement of late kinematic granitoids was tectonically controlled in two main directions, $150^{\circ} \mathrm{NE}$ and $20^{\circ} \mathrm{NE}$, which are well represented in the stretching of the magnetic lineations. The distribution and orientation of magnetic foliations found in this area were subdivided into two groups: (1) more or less circular intrusive plutons displaying steep concentric foliations (Serra da Estrela); and (2) in large granitic zones, namely on the eastern side of the Manteigas-Vilariça fault (MVF), where the foliations are medium to deep, trending NE-SW to N-S. The magnetic lineations displayed constant orientations over large areas (essentially NNW-SSE and NNE-SSW to N-S), with shallow to moderate plunges. In the eastern side of MVF, the lineations displayed preferential NNE-SSW to N-S orientations.

Geographically, Capinha granites are located on the eastern side of MVF (Figures 1 and 2). The magnetic fabric found for the Capinha is similar to that proposed by [122] for granites in the Covilhã-Guarda alignment; however, the dip in the magnetic fabric is shallower in Capinha compared to the others. This can be explained by the suit erosion level, where the outcrop of Capinha represents the roof of the body (see the previous explanation), and the granitic outcrops between Covilhã-Guarda (corresponding to biotite-rich granites) represent a deeper level.

\subsection{The Fault System in the FSEC Region}

The definition of the maximum compression stress $\left(\sigma_{1}\right)$ orientation during late-Variscan fracturing is still a controversial subject of discussion. It is commonly considered that $312 \mathrm{Ma}$ is the lower limit of the so-called Late-Variscan wrench-faulting period responsible for the fault system with a mean dextral strike of $25^{\circ} \mathrm{NE}$ and sinistral strike of $\mathrm{N} 80^{\circ} \mathrm{E}$. However, the $25^{\circ} \mathrm{NE}$ system was dextral in the late stages of the Variscan orogeny and sinistral during the Alpine Cycle, which affected all post- $\mathrm{D}_{3}$ granites (e.g., [57]). In north and central Portugal, four main sub-vertical fault systems were recognized: $25^{\circ} \mathrm{N}$ $\pm 25^{\circ} \mathrm{E}$ (or NNE-SSW), $80^{\circ} \mathrm{N} \pm 20^{\circ} \mathrm{E}$ (ENE-WSW), $155^{\circ} \mathrm{N} \pm 15^{\circ} \mathrm{E}$ (or NW-SE) and $110^{\circ} \mathrm{N} \pm 10^{\circ} \mathrm{E}$ (or WNW-ESE). The $155^{\circ} \mathrm{N} \pm 15^{\circ} \mathrm{E}$ and the $110^{\circ} \mathrm{N} \pm 10^{\circ} \mathrm{E}$ systems display a complex history inherited from the early Variscan deformation (e.g., $[44,54,57])$.

The fracturing at outcrop scale in the Capinha granite is homogeneous, ranging between $\mathrm{N} 20^{\circ}$ and $50^{\circ} \mathrm{E}$ (Figure 14), fitting in the $25^{\circ} \mathrm{N} \pm 25^{\circ} \mathrm{E}$ (or NNE-SSW) strike-slip system. On the other hand, the microfracturing represented here by the fluid inclusion planes exhibits heterogeneous fracturing at $25^{\circ} \mathrm{N} \pm 25^{\circ} \mathrm{E}$ and $80^{\circ} \mathrm{N} \pm 20^{\circ} \mathrm{E}$. Thus, it is suggested that during the ascent, emplacement, and complete consolidation of Capinha granite, the main compression stress was NE-SW oriented, which is demonstrated by the magnetic directional data and in the first brittle deformation marked in the FIP orientation. Later, the maximum compression rotated NNW-SSE. During the Alpine orogeny, a second stage of brittle deformation developed NE-SW $\left(20^{\circ} \mathrm{N}-50^{\circ} \mathrm{E}\right)$ fractures in the granite.

\subsection{Tectonic Constraints and Emplacement Mechanism}

The Capinha granite intruded into the PS late-Variscan granite, dated ca. $304.1 \pm 3.9 \mathrm{Ma}$ and classified as late- $\mathrm{D}_{3}$ [83] (Figures 2 and 3).

The importance of the $\mathrm{N} 150^{\circ}-155^{\circ}$ E and $\mathrm{N} 20^{\circ}-25^{\circ}$ E strike-slip faults in the Serra da Estrela region were previously mentioned [122] in the ascent and emplacement of the late- to post- $\mathrm{D}_{3}$ biotite-rich granites. The reactivation of these sets of strike-slip faults is well recorded in the region (see Section 3 . Fundão-Serra da Estrela-Capinha region). The strong reactivation of the $\mathrm{N}^{\circ} 5^{\circ} \pm 25^{\circ}$ E strike-slip faults, inherited from the $\mathrm{D}_{3}$-Variscan phase and parallel to the MVF, provided zones for the emplacement of late-Variscan granites, which, in turn, were cut by quartz veins in the same direction (Figures 2 and 3). 


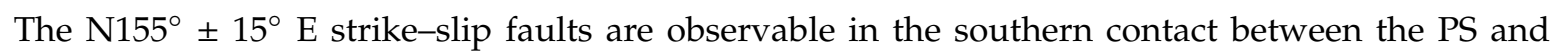
$\mathrm{BC}$ granites.

In Capinha granite, the $\mathrm{N} 155^{\circ} \pm 15^{\circ} \mathrm{E}$ system is poorly represented and only marked by some lineations in the north zone (and only in ca. 5\% of the regional fracturing (Figure 14)). On the other hand, the $\mathrm{N}^{\circ} 5^{\circ} \pm 25^{\circ}$ E system is recorded by magnetic lineations in the whole granite structure (Figure 13b) and also in brittle deformation at several scales. Therefore, we propose that the ascent and emplacement of Capinha magma was controlled by the intersection between the dextral $\mathrm{N} 25^{\circ} \pm$ $25^{\circ} \mathrm{E}$ and the dextral $\mathrm{N} 155^{\circ} \pm 15^{\circ} \mathrm{E}$ strike-slip faults, where the latter is less expressive and acted only as channel conduit for the ascent of the magma. The $\mathrm{N} 25^{\circ} \pm 25^{\circ}$ E fault strongly controlled the orientation of the magnetic lineations and, consequently, the magma flow. The intersection between these two systems is marked in the northern boundary of the Capinha.

The emplacement of granites is still a frequent topic of discussion, particularly concerning the mechanisms of pluton construction ([20,123-129] and the references therein). The Capinha granite clearly cut off contact between PS biotite-rich granites and metasedimentary sequences and its emplacement does not suggest deformation in the host rocks, indicating passive emplacement. The evidence of intense fracturing at a regional scale may facilitate the ascent and emplacement of the magma [130-132]. In this way, the magma ascent was controlled only by tectonics related to the strike-slip system, which helped the magma rise due to the buoyancy forces resulting from the density difference between the magma (usually less dense) and the country rock. The lateral spread of the magma occurred in the interface between lithologies with contrasting rheologic behaviors. The progression stopped due to an increase in magma viscosity, and when the magma approached a solidus state, it acquired high $P_{\text {para }}$ in the pluton peripheries and low-T solid state microstructures.

\subsection{FSEC Granites and Their Metallogenic Implications}

$\mathrm{Sn}(\mathrm{Li})$ mineralizations occur mainly in aplite-pegmatite sills and quartz veins that are generally intrusive in biotite-rich granites. The north-east area of Belmonte-Gonçalo, contains aplite-pegmatite sills with lepidolite and cassiterite ( $\mathrm{Li}-\mathrm{Sn})$ intrusive in late- $\mathrm{D}_{3}$ biotite-rich coarse-grained porphyritic granites (Peroviseu-Seia), as well as in the exocontact of late- to post- $\mathrm{D}_{3}$ two micas granite (e.g., Fráguas granite). This spatial association suggests that $\mathrm{Sn}(\mathrm{Li})$ mineralizations are associated with Fráguas granite (Sn 62 ppm) [70]. This granite's relationship to the mineralizations, geochemical signatures and evolved degree (Figure 10) of the Fráguas granite allows us to classify it as an Sn-bearing granite [133].

$\mathrm{W}$ and W-Sn mineralizations occur in the quartz veins hosted in the PS and Capinha granites and cut the geological contact between the PS and SGC. Several W and W-Sn occurrences were recognized in the Capinha area (Figure 16):

1. W quartz veins in the contact SGC/Peroviseu-Seia granite near Capinha (e.g., Peroviseu, Mata, Ribeiro do Salgueiro, Caverna and Covões);

2. W quartz veins in Capinha granite (e.g., Castelo Velho);

3. W (Sn) quartz veins in the Peroviseu-Seia granite near Salgueiro (e.g., Pombal Lameiros, Veias and Malta).

The preferential occurrence of several $\mathrm{W}$ and $\mathrm{W}-\mathrm{Sn}$ mineralizations near the Capinha granite suggests that the mineralization is related to the emplacement of this post- $\mathrm{D}_{3}$ granite, which is enriched in Sn ( 17 ppm) and W ( 10 ppm).

As mentioned previously, similar W-Sn mineralizations occur in the SGC where no granites outcrop, with Panasqueira being an example of this kind of ore deposit (and where a two-mica granite was recognized in drill cores). The geological settings of the $\mathrm{W}$ and $\mathrm{W}-\mathrm{Sn}$ mineralizations in Capinha and Panasqueira are similar. The emplacement of post-tectonic Capinha granite and the greisenized cupula linked to the two-mica granite in Pasqueira suggest that the emplacement of post- $\mathrm{D}_{3}$ peraluminous granites played an important role as a source of W-Sn metals and heat, which stimulated the remobilization of metal enriched fluids and the resulting concentration of spatially associated W-Sn 
ore deposits. Primary W and W-Sn deposits are the result of hydrothermal systems commonly related to magmatic rocks of a granitic composition and are developed in apical high-level portions of granites, e.g., Capinha, where W accumulated in residual evolved fluids during fractional crystallization.

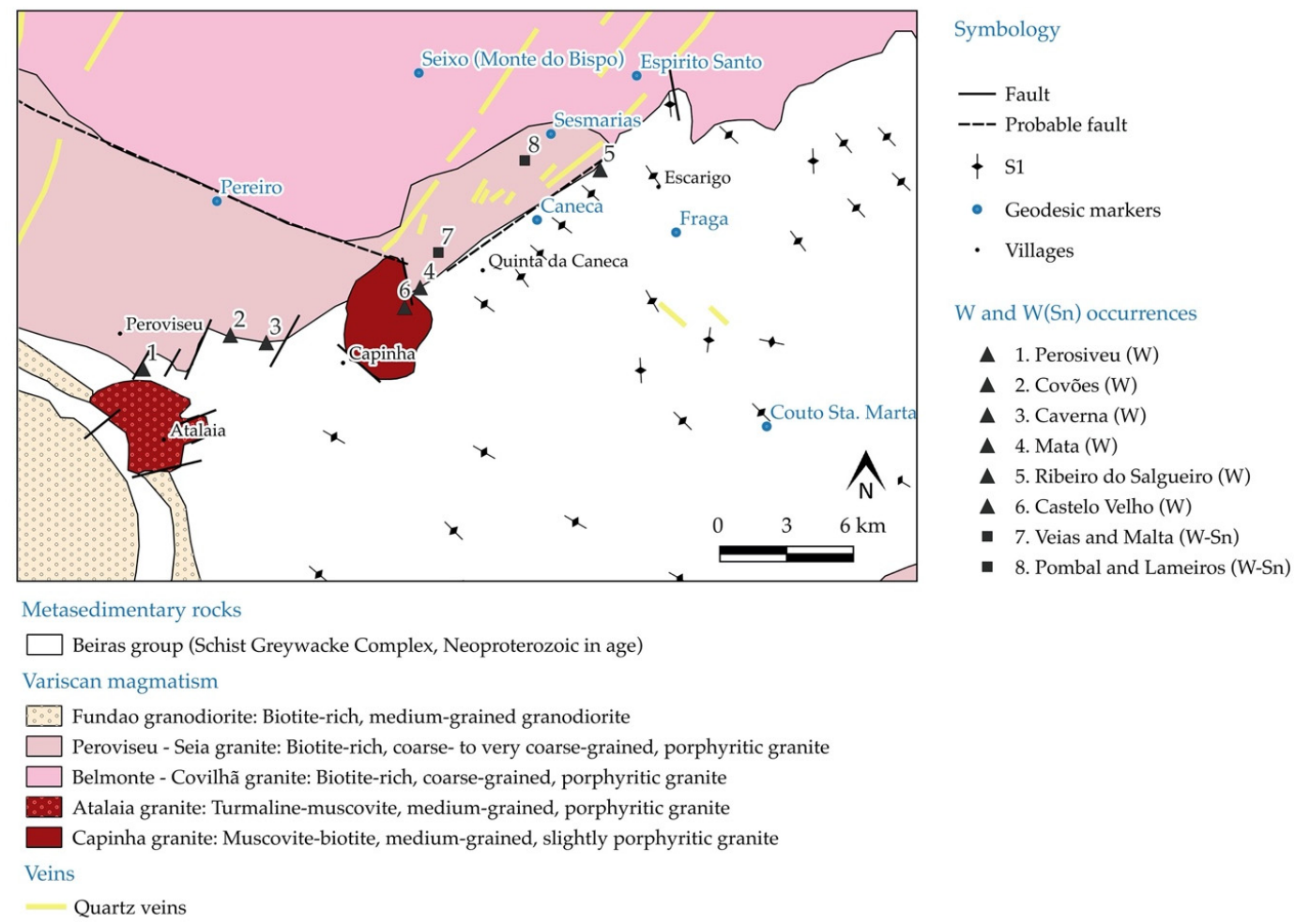

Figure 16. Geological sketch map of the Capinha area showing the association between the outcrop lithologies and the W and W-Sn metallic occurrences $[66,67,81,82]$. Note: the precise localizations of the metallic occurrences were taken from the Sistema de Informação de ocorrências e Recursos Minerais Portugueses (SIORMP) [134].

\subsection{Capinha Granite: Syn- and Post-Emplacement Model}

Based on the previous data and subsequent discussion, a four-stage model of emplacement for the post- $\mathrm{D}_{3}$ Capinha granite (Figure 17) is proposed:

Stage I: In the late-Variscan extensional setting, the reactivation of $25^{\circ} \mathrm{N} \pm 25^{\circ} \mathrm{E}$ and $155^{\circ} \mathrm{N} \pm$ $15^{\circ}$ E strike-slip crustal scale faults led to the opening of spaces, which acted as feeder channels for the passive ascent of the Capinha magma. The feeder zone was located in the northern boundary, as evidenced by the high values of $P_{\text {para }}$, prolate ellipsoid shapes and the vertical magnetic fabric.

Stage II: The vertical ascent of magma through the dykes along the crustal strike-slip faults was facilitated by buoyancy forces. The existence of a contrasting rheologic boundary favors lateral magma spread from NNE to SSW, forming an asymmetric tongue-shaped laccolith.

Stage III: During the ascent, the magma underwent magmatic differentiation processes, with the residual magmatic-hydrothermal fluid becoming enriched in incompatible ( $\mathrm{Rb}$ and $\mathrm{W})$ and volatile elements. This fluid's geochemical signature and spatial relationship with the W and W (Sn) mineralizations suggest that Capinha played an important role in the metallic concentrations.

Stage IV: After complete crystallization, the Capinha granite experienced its first brittle deformation event, which is recorded in the NE-SW to ENE-WSW FIP and is consistent with NE-SW oriented $\sigma 1$. Later, the rotation of the maximum compression from NE-SW to NNW-SSE led to a second stage of brittle deformation, which generated NE-SW fractures in the granite. 


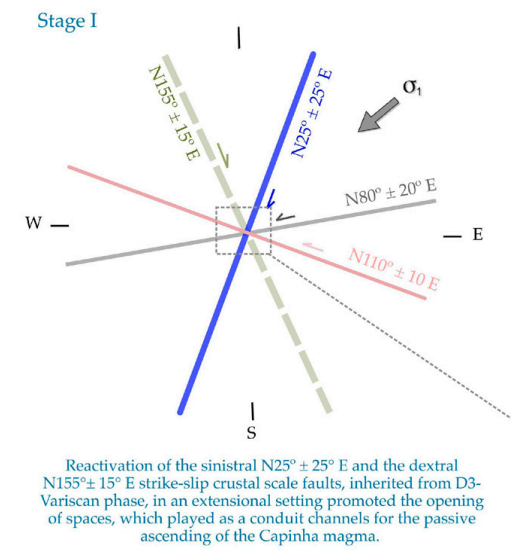

Stage II

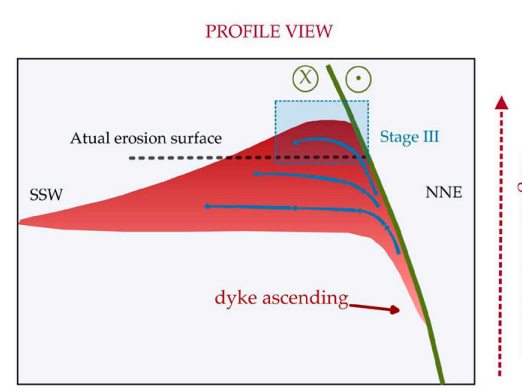

\section{Capinha granite}

- $\mathrm{N} 155^{\circ} \pm 15^{\circ} \mathrm{E}$ fracturing system

N $25^{\circ} \pm 25^{\circ} \mathrm{E}$ fracturing system

$\longrightarrow$ Magma flow

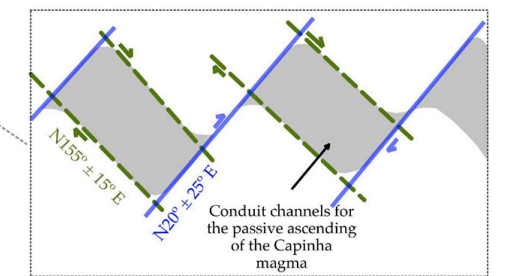

PLAN VIEW

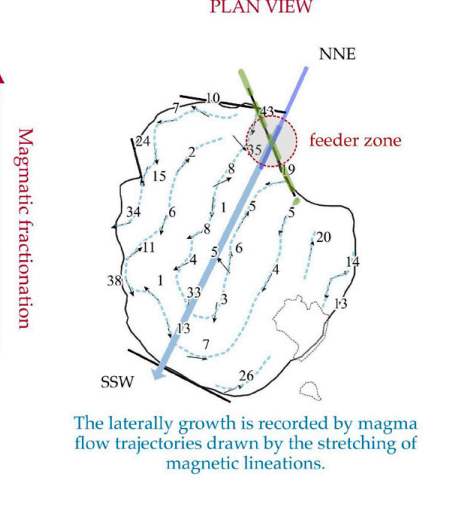

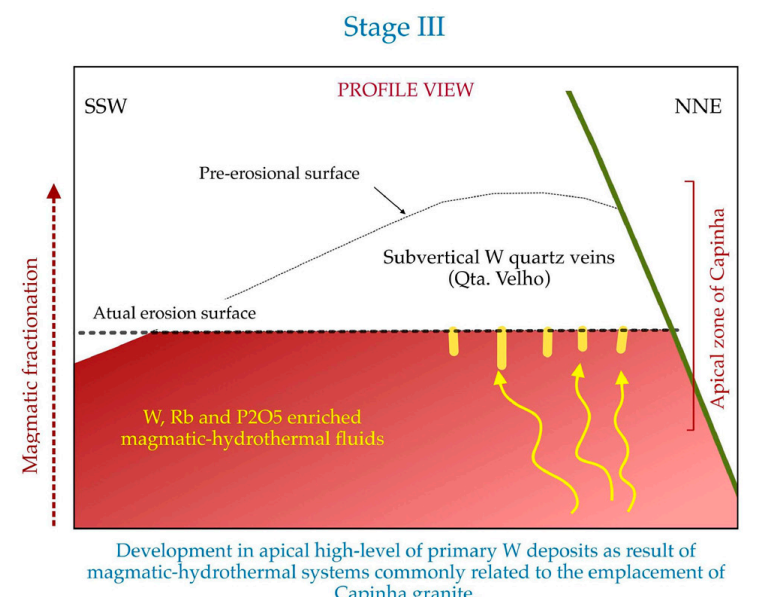

Stage IV
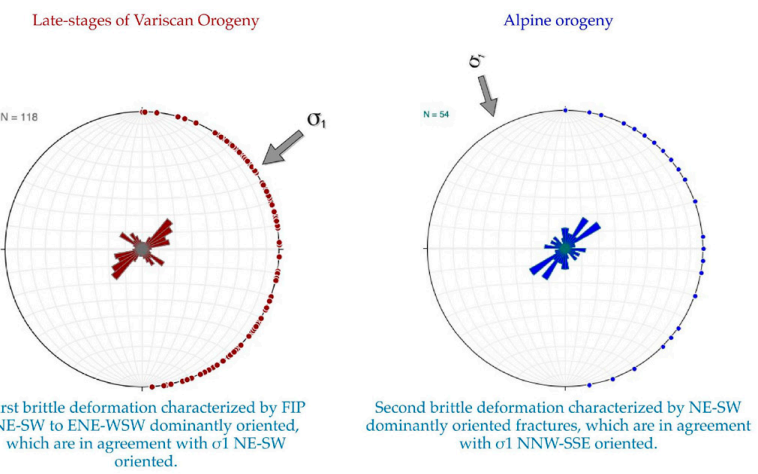

Figure 17. Schematic model proposed for the ascent, emplacement and brittle deformation of the Capinha granite. 


\section{Conclusions}

The geochemical data together with the microstructures and the AMS results provided the following conclusions:

- Studying the geochemical behaviors of FSEC granites allowed us to identify distinct and independent differentiation trends, namely, Peroviseu-Seia (PS), Belmonte-Covilhã (BC), Fráguas and Capinha. The Fráguas and Capinha are more evolved than BC and BC.

- Capinha granite has a homogeneous spatial distribution in $K_{\mathrm{m}}$, displaying values below $73.4 \mu \mathrm{SI}$, thereby indicating that magnetic mineralogy is dominated by paramagnetic minerals such as biotite, which is classified as an ilmenite-type granite. The generally low magnetic anisotropy in the whole area is typical of post-Variscan muscovite-biotite granites, where $P_{\text {para }}$ corresponds to a weak orientation of the fabric and also a low degree of deformation. The highest values were found in the peripheries, especially in the north-eastern direction, corresponding to the late-deformation patterns caused by the solidification of magma against the host rocks. The magnetic ellipsoid shapes are, in general, oblate, indicating a planar fabric, which may indicate the roof of the granite suit. Prolate shapes were found in the north-eastern zone, fitting the zones with high $P_{\text {para }}$.

- The granite displays NE-SW striking foliations associated with NNE-SSW magnetic lineations parallel to the long axis of the pluton, showing that the acquisition of the magnetic fabric resulted from magma stretching parallel to the magma flow (from NNE to SSW), at the end of the last ductile Variscan deformation phase $\left(\mathrm{D}_{3}\right)$. This enhanced the role of $155^{\circ} \mathrm{N} \pm 15^{\circ} \mathrm{E}$ and $25^{\circ} \mathrm{N} \pm$ $25^{\circ}$ E structures on the magma's ascent and emplacement. The general sub-horizontal magnetic fabric suggests that the outcrop is the roof of the suit. Vertical foliations associated with vertical lineations in the north-eastern boundary suggest the location of a deep feeder zone.

- The ascent of the magma in the dyke structures at high structural levels, as well as the lateral spread of the magma in the contrasting rheologic boundary, allowed the construction of an asymmetric tongue-shaped laccolith, with its root located in the north-eastern zone.

- After complete consolidation, the late-Variscan faulting indicates the reactivation of inherited structures, and the first brittle deformation was recorded in the FIP, with the main compression being oriented NE-SW. After the rotation of the maximum compression to NNW-SSE, during Alpine orogeny, a second stage of brittle deformation was registered, developing fractures in the granite (generally NE-SW $\left(20^{\circ} \mathrm{N}-50^{\circ} \mathrm{E}\right)$ oriented).

- The FSEC region is characterized by several metallic occurrences, and the spatial distribution of the distinct types of mineralizations is not accidental. The Sn mineralizations in pegmatites and quartz veins with cassiterite are hosted by PS and BC granites, but only those near Fráguas granite, suggesting that the mineralization source is related to the Fráguas ( $\mathrm{Sn} \sim 62 \mathrm{ppm}$ ) granite. Therefore, the primary $\mathrm{W}$ and $\mathrm{W}-\mathrm{Sn}$ deposits are the result of hydrothermal systems commonly related to magmatic rocks with a granitic composition and are developed in apical high-level portions of granites, such as Capinha and Panasqueira.

Author Contributions: Conceptualization, A.G., H.S. and F.N.; data curation, A.G., H.S. and F.N.; formal analysis, A.G., H.S. and F.N.; funding acquisition, H.S. and F.N.; investigation, A.G., H.S. and F.N.; methodology, A.G., H.S. and F.N.; project administration, A.G. and H.S.; resources, A.G., H.S. and F.N.; software, A.G., H.S. and F.N.; supervision, H.S. and F.N.; validation, A.G., H.S. and F.N.; visualization, A.G., H.S. and F.N.; writing-original draft, A.G., H.S. and F.N.; writing-review and editing, A.G., H.S. and F.N. All authors have read and agreed to the published version of the manuscript

Funding: This research was funded by the Fundação para a Ciência e Tecnologia (FCT), Grant Number SFRH/BD/115324/2016.

Acknowledgments: This work was supported by the Portuguese Foundation for Science and Technology (FCT) project UIDB/04,683/2020 - ICT (Institute of Earth Sciences). The authors thank the POCTEP-Interreg Project 0284_ESMIMET_3_E "Development of exploitation environmental and energy techniques in metallic mining" for their technical support. The authors thank the Department of Geosciences, Environment and Spatial Planning at the Faculty of Sciences of the University of Porto for making their laboratories available for carrying out the 
studies presented in this study. The authors thank Duarte Silva and José Carlos Oliveira for their help in the sampling and fieldwork and Cândida Neto for her help in the SEM-EDS analysis. The authors deeply thank Lourenço Pereira from the CIMPOR, AGREPOR, SA, Centro de Exploração do Fundão, for the samples collected in the quarry for whole rock geochemistry. The authors thank the anonymous reviewers for their helpful comments and suggestions, which clearly improved the quality of the manuscript.

Conflicts of Interest: The authors declare no conflicts of interest. The funders had no role in the design of the study; in the collection, analyses or interpretation of the data; in the writing of the manuscript or in the decision to publish the results.

\section{Appendix A}

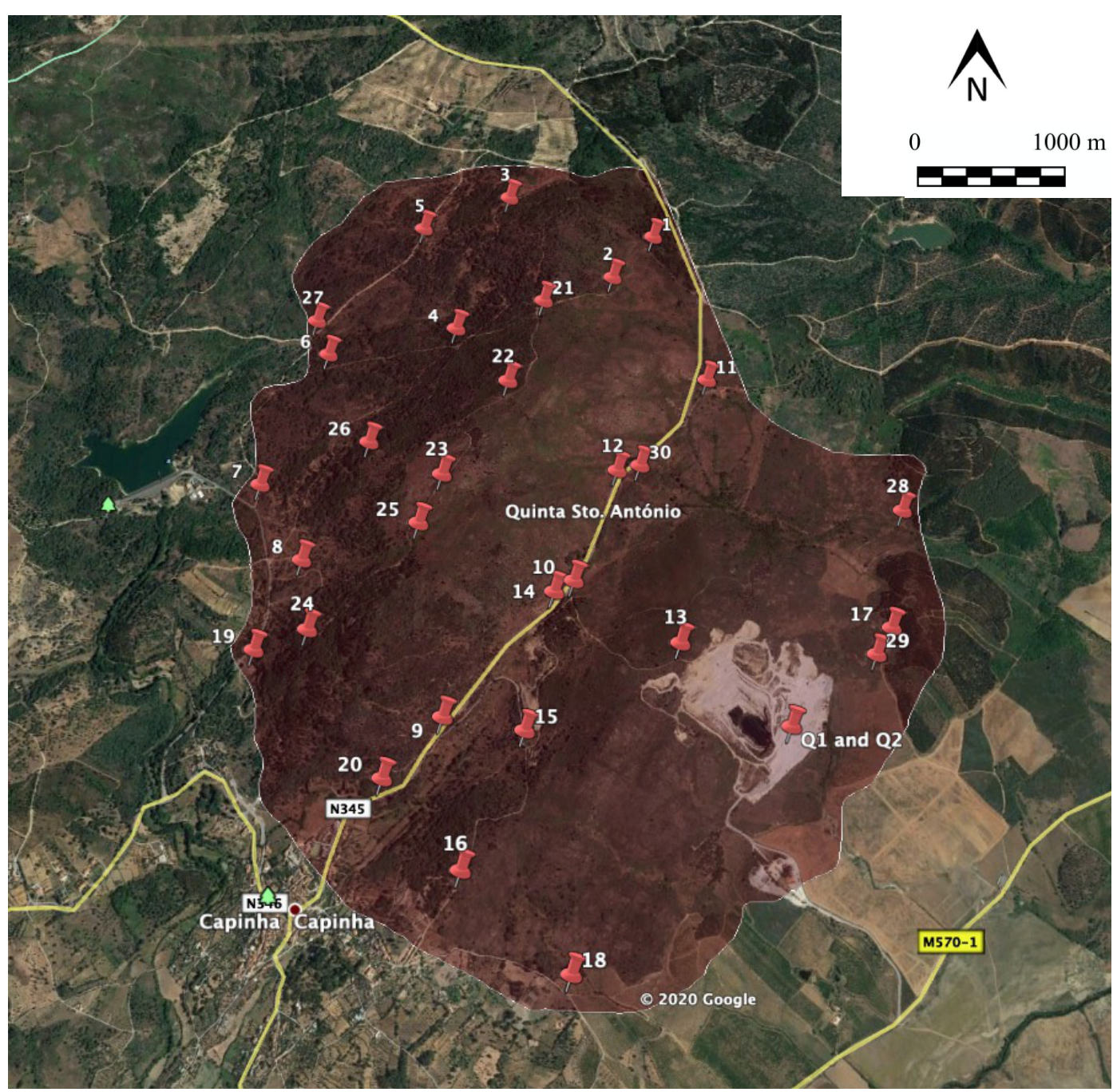

Figure A1. Location of the sampling sites for the Capinha granite (Google Earth image accessed on 5 May 2020). 
Table A1. Geographic coordinates, elevations, methods applied, and number of samples collected from each sampling site in Capinha.

\begin{tabular}{|c|c|c|c|c|c|}
\hline ID & Latitude & Longitude & Elevation (Above Sea) & Methods Applied & Samples Collected \\
\hline 1 & $40^{\circ} 13^{\prime} 23.520^{\prime \prime} \mathrm{N}$ & $7^{\circ} 21^{\prime} 41.760^{\prime \prime} \mathrm{W}$ & $585 \mathrm{~m}$ & $\begin{array}{l}\text { Petrography, microstructures, whole rock geochemistry, anisotropy of } \\
\text { magnetic susceptibility and fluid inclusion planes }\end{array}$ & 4 oriented cores \\
\hline 2 & $40^{\circ} 13^{\prime} 17.400^{\prime \prime} \mathrm{N}$ & $7^{\circ} 21^{\prime} 48.240^{\prime \prime} \mathrm{W}$ & $600 \mathrm{~m}$ & Anisotropy of magnetic susceptibility & 6 oriented cores \\
\hline 3 & $40^{\circ} 13^{\prime} 28.200^{\prime \prime} \mathrm{N}$ & $7^{\circ} 22^{\prime} 5.520^{\prime \prime} \mathrm{W}$ & $570 \mathrm{~m}$ & Anisotropy of magnetic susceptibility & 6 oriented cores \\
\hline 4 & $40^{\circ} 13^{\prime} 10.200^{\prime \prime} \mathrm{N}$ & $7^{\circ} 22^{\prime} 13.080^{\prime \prime} \mathrm{W}$ & $598 \mathrm{~m}$ & $\begin{array}{l}\text { Petrography, microstructures, whole rock geochemistry, anisotropy of } \\
\text { magnetic susceptibility and fluid inclusion planes }\end{array}$ & 5 oriented cores \\
\hline 5 & $40^{\circ} 13^{\prime} 24.960^{\prime \prime} \mathrm{N}$ & $7^{\circ} 22^{\prime} 19.920^{\prime \prime} \mathrm{W}$ & $577 \mathrm{~m}$ & Anisotropy of magnetic susceptibility & 5 oriented cores \\
\hline 6 & $40^{\circ} 13^{\prime} 7.680^{\prime \prime} \mathrm{N}$ & $7^{\circ} 22^{\prime} 33.960^{\prime \prime} \mathrm{W}$ & $541 \mathrm{~m}$ & Anisotropy of magnetic susceptibility & 4 oriented cores \\
\hline 7 & $40^{\circ} 12^{\prime} 50.639^{\prime \prime} \mathrm{N}$ & $7^{\circ} 22^{\prime} 42.637^{\prime \prime} \mathrm{W}$ & $518 \mathrm{~m}$ & Anisotropy of magnetic susceptibility & 7 oriented cores \\
\hline 8 & $40^{\circ} 12^{\prime} 41.040^{\prime \prime} \mathrm{N}$ & $7^{\circ} 22^{\prime} 34.680^{\prime \prime} \mathrm{W}$ & $529 \mathrm{~m}$ & Anisotropy of magnetic susceptibility & 4 oriented cores \\
\hline 9 & $40^{\circ} 12^{\prime} 22.680^{\prime \prime} \mathrm{N}$ & $7^{\circ} 22^{\prime} 11.640^{\prime \prime} \mathrm{W}$ & $519 \mathrm{~m}$ & Anisotropy of magnetic susceptibility & 5 oriented cores \\
\hline 10 & $40^{\circ} 12^{\prime} 38.160^{\prime \prime} \mathrm{N}$ & $7^{\circ} 21^{\prime} 52.920^{\prime \prime} \mathrm{W}$ & $564 \mathrm{~m}$ & $\begin{array}{l}\text { Petrography, microstructures, anisotropy of magnetic susceptibility and } \\
\text { fluid inclusion planes }\end{array}$ & 5 oriented cores \\
\hline 11 & $40^{\circ} 13^{\prime} 4.071^{\prime \prime} \mathrm{N}$ & $7^{\circ} 21^{\prime} 32.912^{\prime \prime} \mathrm{W}$ & $546 \mathrm{~m}$ & $\begin{array}{l}\text { Petrography, microstructures, whole rock geochemistry, anisotropy of } \\
\text { magnetic susceptibility and fluid inclusion planes }\end{array}$ & 5 oriented cores \\
\hline 12 & $40^{\circ} 12^{\prime} 52.001^{\prime \prime} \mathrm{N}$ & $7^{\circ} 21^{\prime} 46.878^{\prime \prime} \mathrm{W}$ & $556 \mathrm{~m}$ & Anisotropy of magnetic susceptibility & 5 oriented cores \\
\hline 13 & $40^{\circ} 12^{\prime} 30.841^{\prime \prime} \mathrm{N}$ & $7^{\circ} 21^{\prime} 36.885^{\prime \prime} \mathrm{W}$ & $568 \mathrm{~m}$ & Anisotropy of magnetic susceptibility & 4 oriented cores \\
\hline 14 & $40^{\circ} 12^{\prime} 36.830^{\prime \prime} \mathrm{N}$ & $7^{\circ} 21^{\prime} 55.803^{\prime \prime} \mathrm{W}$ & $567 \mathrm{~m}$ & Anisotropy of magnetic susceptibility & 4 oriented cores \\
\hline 15 & $40^{\circ} 12^{\prime} 21.098^{\prime \prime} \mathrm{N}$ & $7^{\circ} 21^{\prime} 59.448^{\prime \prime} \mathrm{W}$ & $533 \mathrm{~m}$ & $\begin{array}{l}\text { Petrography, microstructures, whole rock geochemistry, anisotropy of } \\
\text { magnetic susceptibility and fluid inclusion planes }\end{array}$ & 5 oriented cores \\
\hline 16 & $40^{\circ} 12^{\prime} 6.106^{\prime \prime} \mathrm{N}$ & $7^{\circ} 22^{\prime} 7.633^{\prime \prime} \mathrm{W}$ & $516 \mathrm{~m}$ & Anisotropy of magnetic susceptibility & 5 oriented cores \\
\hline 17 & $40^{\circ} 12^{\prime} 33.197^{\prime \prime} \mathrm{N}$ & $7^{\circ} 21^{\prime} 5.113^{\prime \prime} \mathrm{W}$ & $497 \mathrm{~m}$ & $\begin{array}{l}\text { Petrography, microstructures, anisotropy of magnetic susceptibility and } \\
\text { fluid inclusion planes }\end{array}$ & 5 oriented cores \\
\hline 18 & $40^{\circ} 11^{\prime} 55.571^{\prime \prime} \mathrm{N}$ & $7^{\circ} 21^{\prime} 51.777^{\prime \prime} \mathrm{W}$ & $474 \mathrm{~m}$ & $\begin{array}{l}\text { Petrography, microstructures, whole rock geochemistry, anisotropy of } \\
\text { magnetic susceptibility and fluid inclusion planes }\end{array}$ & 5 oriented cores \\
\hline 19 & $40^{\circ} 12^{\prime} 30.487^{\prime \prime} \mathrm{N}$ & $7^{\circ} 22^{\prime} 40.665^{\prime \prime} \mathrm{W}$ & $506 \mathrm{~m}$ & $\begin{array}{l}\text { Petrography, microstructures, whole rock geochemistry, anisotropy of } \\
\text { magnetic susceptibility and fluid inclusion planes }\end{array}$ & 5 oriented cores \\
\hline 20 & $40^{\circ} 12^{\prime} 15.987^{\prime \prime} \mathrm{N}$ & $7^{\circ} 22^{\prime} 19.970^{\prime \prime} \mathrm{W}$ & $499 \mathrm{~m}$ & Anisotropy of magnetic susceptibility & 5 oriented cores \\
\hline 21 & $40^{\circ} 13^{\prime} 12.7452^{\prime \prime} \mathrm{N}$ & $7^{\circ} 21^{\prime} 42.768^{\prime \prime} \mathrm{W}$ & $586 \mathrm{~m}$ & Anisotropy of magnetic susceptibility & 5 oriented cores \\
\hline 22 & $40^{\circ} 13^{\prime} 1.92^{\prime \prime} \mathrm{N}$ & $7^{\circ} 22^{\prime} 3.774^{\prime \prime} \mathrm{W}$ & $673 \mathrm{~m}$ & Anisotropy of magnetic susceptibility & 5 oriented cores \\
\hline 23 & $40^{\circ} 12^{\prime} 50.1732^{\prime \prime} \mathrm{N}$ & $7^{\circ} 22^{\prime} 13.098^{\prime \prime} \mathrm{W}$ & $655 \mathrm{~m}$ & Anisotropy of magnetic susceptibility & 4 oriented cores \\
\hline 24 & $40^{\circ} 12^{\prime} 32.3496^{\prime \prime} \mathrm{N}$ & $7^{\circ} 22^{\prime} 32.0952^{\prime \prime} \mathrm{W}$ & $571 \mathrm{~m}$ & Anisotropy of magnetic susceptibility & 5 oriented cores \\
\hline 25 & $40^{\circ} 12^{\prime} 44.514^{\prime \prime} \mathrm{N}$ & $7^{\circ} 22^{\prime} 16.3416^{\prime \prime} \mathrm{W}$ & $626 \mathrm{~m}$ & Anisotropy of magnetic susceptibility & 5 oriented cores \\
\hline 26 & $40^{\circ} 12^{\prime} 54.9864^{\prime \prime} \mathrm{N}$ & $7^{\circ} 22^{\prime} 25.2372^{\prime \prime} \mathrm{W}$ & $606 \mathrm{~m}$ & Anisotropy of magnetic susceptibility & 5 oriented cores \\
\hline 27 & $40^{\circ} 13^{\prime} 9.9372^{\prime \prime} \mathrm{N}$ & $7^{\circ} 22^{\prime} 38.0388^{\prime \prime} \mathrm{W}$ & $523 \mathrm{~m}$ & AMS Anisotropy of magnetic susceptibility & 5 oriented cores \\
\hline 28 & $40^{\circ} 12^{\prime} 47.7612^{\prime \prime} \mathrm{N}$ & $7^{\circ} 21^{\prime} 2.3796^{\prime \prime} \mathrm{W}$ & $482 \mathrm{~m}$ & Anisotropy of magnetic susceptibility & 5 oriented cores \\
\hline 29 & $40^{\circ} 12^{\prime} 36.234^{\prime \prime} \mathrm{N}$ & $7^{\circ} 21^{\prime} 8.01^{\prime \prime} \mathrm{W}$ & $500 \mathrm{~m}$ & Anisotropy of magnetic susceptibility & 6 oriented cores \\
\hline 30 & $40^{\circ} 12^{\prime} 52.7947^{\prime \prime} \mathrm{N}$ & $7^{\circ} 21^{\prime} 43.3656^{\prime \prime} \mathrm{W}$ & $545 \mathrm{~m}$ & Anisotropy of magnetic susceptibility & 6oriented cores \\
\hline Q1 and Q2 & $40^{\circ} 12^{\prime} 21.91^{\prime \prime} \mathrm{N}$ & $7^{\circ} 21^{\prime} 20.18^{\prime \prime} \mathrm{W}$ & $481 \mathrm{~m}$ & Whole rock geochemistry & About $20 \mathrm{~kg}$ \\
\hline
\end{tabular}




\section{References}

1. Bouchez, J.L.; Gleizes, G.; Djouadi, M.T.; Rochette, P. Microstructure and magnetic susceptibility applied to emplacement kinematics of granites: The example of the Foix pluton (French Pyrenees). Tectonophysics 1990, 184, 157-171. [CrossRef]

2. Gleizes, G.; Dédélec, A.; Bouchez, J.L. Magnetic susceptibility of Mont-Louis Andorra Ilmenite-Type granite (Pyrenees): A New Tool for the Petrographic Characterization and Regional Mapping of Zoned Granite Plutons. J. Geophys Res. 1993, 98, 4317-4331. [CrossRef]

3. Paterson, S.R.; Fowler, T.K.; Schmidt, K.L.; Yoshinobu, A.S.; Yuan, E.S.; Miller, R.B. Interpreting magmatic fabric patterns in plutons. Lithos 1998, 44, 53-82. [CrossRef]

4. Park, A.F. Granites and mineralization. In Petrology; Encyclopedia of Earth Science; Springer: Boston, MA, USA, 1989. [CrossRef]

5. Sial, A.N.; Bettencourt, J.S.; De Campos, C.P.; Ferreira, V.P. Granite-related ore deposits: An introduction. J. Geol. Soc. Lond. Spec. Publ. 2011, 350, 1-5. [CrossRef]

6. Pirajno, F. Hydrothermal Processes and Mineral Systems, 1st ed.; Springer: Dordrecht, The Netherlands, 2009. [CrossRef]

7. Hrouda, F. Magnetic Anisotropy of rocks and its application in geology and geophysics. Geophys Surv. 1982, 5, 37-82. [CrossRef]

8. Tarling, D.H.; Hrouda, F. The Magnetic Anisotropy of Rocks, 1st ed.; Chapman and Hall: London, UK, 1993; ISBN 978-0-412-49880-0.

9. Knight, M.D.; Walker, G.P.L. Magma flow directions in dikes of the Koolau complex, Oahu, determined from magnetic fabric studies. J. Geophys Res. 1988, 93, 4301-4319. [CrossRef]

10. Bouchez, J.L. Granite is never isotropic: An introduction to AMS studies of granitic rocks. In Granite: From Segregation of Melt to Emplacement Fabrics; Bouchez, J.L., Hutton, D.H.W., Stephens, W.E., Eds.; Kluwer Academic Publishers: Dordrecht, The Netherlands, 1997; pp. 95-112.

11. Pitcher, W.S. The nature, ascent and emplacement of granitic magmas. J. Geol. Soc. Lond. 1979, 136, 627-662. [CrossRef]

12. Borradaile, G.J. Magnetic susceptibility, petrofabrics and strain. Tectonophysics 1988, 156, 1-20. [CrossRef]

13. Bouchez, J.L.; Diot, H. Nested granites in question: Contrasted emplacement kinematics of independent magmas in the Zaër pluton, Morocco. Geology 1990, 18, 966-969. [CrossRef]

14. Borradaile, G.J.; Jackson, M. Anisotropy of magnetic susceptibility (AMS): Magnetic petrofabrics of deformed rocks. J. Geol. Soc. Lond. 2004, 238, 299-360, Special Publications. [CrossRef]

15. Borradaile, G.J.; Jackson, M. Structural geology, petrofabrics and magnetic fabrics (AMS, AARM, AIRM). J. Struct. Geol. 2010, 32, 1519-1551. [CrossRef]

16. Ishihara, S. Major molybdenum deposits and related granitic rocks in Japan. Geol. Surv. Jpn. Rept. 1971, 239, 1-178.

17. Ishihara, S. The magnetite-series and ilmenite-series granitic rocks. Min. Geol. 1977, 27, 293-305. [CrossRef]

18. Rochette, P. Magnetic susceptibility of the rock matrix related to magnetic fabric studies. J. Struct. Geol. 1987, 9, 1243-1257. [CrossRef]

19. Pueyo-Anchuela, O.; Casas-Sainz, A.M.; Pueyo, E.P.; Juan, A.P.; Imaz, A.G. Analysis of the ferromagnetic contribution to the susceptibility by low field and high field methods in sedimentary rocks of the Southern Pyrenees and Northern Ebro foreland basin (Spain). Terra Nova 2013, 25, 307-314. [CrossRef]

20. Nédélec, A.; Bouchez, J.L. Granites: Petrology, Structure, Geological Setting, and Metallogeny, English Translation; Oxford University Press: Oxford, UK, 2015; ISBN 978-0-19-870561-1.

21. Takagi, T. Origin of magnetite- and ilmenite-series granitic rocks in the Japan arc. Am. J. Sci. 2004, 304, 169-204. [CrossRef]

22. Bea, F.; Montero, P.; Molina, J.F. Mafic Precursors, Peraluminous Granitoids, and Late Lamprophyres in the Avila Batholith: A Model for the Generation of Variscan Batholiths in Iberia. J. Geol. 1999, 107, 399-419. [CrossRef]

23. Dias, G.; Leterrier, J. The genesisof felsic-mafic plutonic associations: A Sr and Nd isotopic study of the Hercynian Braga Granitoid Massif (Northern Portugal). Lithos 1994, 32, 207-223. [CrossRef] 
24. Castro, A.; Patiño Douce, A.E.; Corretgé, L.G.; de la Rosa, J.D.; El-Biad, M.; El-Hmidi, H. Origin of peraluminous granites and granodiorites, Iberian massif, Spain: An experimental test of granite petrogenesis. Contrib. Mineral. Petrol. 1999, 135, 255-276. [CrossRef]

25. Dias, G.; Simões, P.P.; Ferreira, N.; Leterrier, J. Mantle and Crustal Sources in the Genesis of Late-Hercynian Granitoids (NW Portugal):Geochemical and Sr-Nd Isotopic Constraints. Gondwana Res. 2002, 5, 287-305. [CrossRef]

26. Janousek, V.; Braithwaiteb, C.J.R.; Bowesb, D.R.; Gerdesc, A. Magma-mixing in the genesis of Hercynian calc-alkaline granitoids: An integrated petrographic and geochemical study of the Sázava intrusion, Central Bohemian Pluton, Czech Republic. Lithos 2004, 78, 67-99. [CrossRef]

27. Neiva, A.M.R.; Williams, I.S.; Ramos, J.M.F.; Gomes, M.E.P.; Silva, M.M.V.G.; Antunes, I.M.H.R. Geochemical and isotopic constraints on the petrogenesis of Early Ordovician granodiorite and Variscan two-mica granites from the Gouveia area, central Portugal. Lithos 2009, 111, 186-202. [CrossRef]

28. Neiva, A.M.R.; Silva, P.B.; Corfu, F.; Ramos, J.M.F. Sequential melting and fractional crystallization: Granites from Guarda-Sabugal area, central Portugal. Chem. Der Erde 2011, 71, 227-245. [CrossRef]

29. Villaseca, C.; Bellido, F.; Pérez-Soba, C.; Billström, K. Multiple crustal sources for post-tectonic I-type granites in the Hercynian Iberian Belt. Miner. Petrol. 2009, 96, 197-211. [CrossRef]

30. Martins, H.C.B.; Sant'Ovaia, H.; Noronha, F. Late-Variscan emplacement and genesis of the Vieira do Minho composite pluton, Central Iberian Zone: Constraints from $\mathrm{U}-\mathrm{Pb}$ zircon geochronology, AMS data and $\mathrm{Sr}-\mathrm{Nd}-\mathrm{O}$ isotope geochemistry. Lithos 2013, 162-163, 221-235. [CrossRef]

31. Costa, M.M.; Neira, A.M.R.; Azevedo, M.R.; Corfu, F. Distinct sources for syntectonic Variscan granitoids: Insights from the Aguiar da Beira region, Central Portugal. Lithos 2014, 196-197, 83-98. [CrossRef]

32. Pereira, M.F.; Díez Fernández, R.; Gama, C.; Hofmann, M.; Gärtner, A.; Linnemann, U. S-type granite generation and emplacement during a regional switch from extensional to contractional deformation (Central Iberian Zone, Iberian autochthonous domain, Variscan Orogeny). Int. J. Earth Sci. 2018, 107, 251-267. [CrossRef]

33. Neiva, J.M.C. Jazigos portugueses de volframite e cassiterite. Com. Serv. Geol. Portugal 1944, 25, 1-251.

34. Thadeu, D. Carta Mineira de Portugal. Notícia Explicativa. Ser. Geol. Port. 1965, 1-46.

35. Schermerhorn, L.J.G. Framework and devolution of Hercynian mineralization in the Iberian Meseta. Leidse Geol. Medelelingen 1981, 52, 23-56.

36. Neiva, A.M.R. Portuguese Granites Associated with Sn-W and Au Mineralizations. Bull. Geol. Soc. Finl. 2002, 74, 79-101. [CrossRef]

37. Noronha, F.; Ribeiro, M.A.; Almeida, A.; Dória, A.; Guedes, A.; Lima, A.; Martins, H.C.B.; Sant'Ovaia, H.; Nogueira, P.; Martins, T.; et al. Jazigos filonianos hidrotermais e aplito-pegmatíticos espacialmente associados a granitos (norte de Portugal). In Geologia de Portugal; Dias, R., Araújo, A., Terrinha, P., Kullberg, J.C., Eds.; -Geologia Pré-mesozóica de Portugal: Escolar Editora, Évora, 2006; Volume 2, pp. 403-438. ISBN 972-778-094-6.

38. Mateus, A.; Noronha, F. Sistemas mineralizantes epigenéticos na Zona Centro Ibérica; expressão da estruturação orogénica meso-A tardivarisca. In Ciências Geológicas: Ensino, Investigação e sua História; Cotelo Neiva, J.M., Ribeiro, A., Mendes Victor, L., Noronha, F., Magalhães Ramalho, M., Eds.; Geologia Aplicada, Chapter 1; Associação Portuguesa de Geólogos/Sociedade Geológica de Portugal: Lisboa, Portugal, 2010; Volume 2, pp. 47-61. ISBN 978-989-96669-1-7.

39. Matte, P. Tectonics and Plate Tectonics Model for the Variscan Belt of Europe. Tectonophysics 1986, 126, 329-374. [CrossRef]

40. Ribeiro, A.; Iglésias, M.; Ribeiro, M.L.; Pereira, E. Modéle géodynamique des Hercynides Ibériques. Mem. Serv. Geol. Port. 1983, 69, 291-293.

41. Ribeiro, A.; Quesada, C.; Dallmeyer, R.D. Geodynamic evolution of the Iberian Massif. In Pre-Mesozoic Geology of Iberia; Dallmeyer, R.D., Martínez Garcia, E., Eds.; Springer-Verlag: Berlin/Heidelberg, Germany, 1990; pp. 399-410.

42. Quesada, C. Geological constraints on the Paleozoic tectonic evolution of tectonostratigraphic terranes in the Iberian Massif. Tectonophysics 1991, 185, 225-245. [CrossRef]

43. Dias, R.; Ribeiro, A.; Romão, J.; Coke, C.; Moreira, N. A review of the arcuate structures in the Iberian Variscides; constraints and genetic models. Tectonophysics 2016, 681, 170-194. [CrossRef]

44. Ribeiro, A. Contribution à l'étude de Traás-os-Montes Oriental. Mem. Serv. Geol Port. 1974, 24. 
45. Noronha, F.; Ramos, J.M.F.; Rebelo, J.A.; Ribeiro, A.; Ribeiro, M.L. Essai de corrélation des phases de déformation hercynienne dans le Nord-Ouest Péninsulaire. Bol. Soc. Geol. Port. 1979, 21, 227-237.

46. Dias, R.; Ribeiro, A. The Ibero-Armorican Arc: A collision effect against an irregular continent? Tectonophysics 1995, 246, 113-128. [CrossRef]

47. Julivert, M.; Fontboté, J.M.; Ribeiro, A.; Conde, L. Mapa Tectónico de la Península Ibérica y Baleares. Escala 1: 1,000,000. Memoria Explicativa. Inst. Geol. Min. España 1974, 113.

48. Farias, P.; Gallastegui, G.; Gonzalez Lodeiro, F.; Marquinez, J.; Martin Parra, L.M.; Martínez Catalan, J.R.; de Pablo Maciaá, J.G.; Rodriguez Fernandez, L.R. Aportaciones al Conocimiento de la Litoestratigrafia y Estructura de Galícia Central. IX Reunião de Geologia do Oeste Peninsular, Porto, 1985; Memórias Museu Laboratório Mineralogia Geologia da Faculdade Ciências Universidade Porto: Porto, Portugal, 1987; Volume 1, pp. 411-431.

49. Lagarde, J.L.; Capdevila, R. Granites and continental collision: Examples from Carboniferous granitoids in the Hercynian Range of Western Europe. Bull. Soc. Géol Fr. 1992, 163, 597-610.

50. Iglésias, M.; Choukroune, P. Shear zones in the Iberian Arc. J. Struct. Geol. 1980, 2, 63-68. [CrossRef]

51. Díez Fernaández, R.; Pereira, M.F. Extensional orogenic collapse captured by strike-slip tectonics: Constraints from structural geology and U-Pb geochronology of the Pinhel shear zone (Variscan orogen, Iberian Massif). Tectonophysics 2016, 691, 290-310. [CrossRef]

52. Bea, F.; Pesquera, A.; Montero, P.; Torres-Ruiz, J.; Gil-Crespo, P.P. Tourmaline 40Ar/39Ar chronology of tourmaline-rich rocks from Central Iberia dates the main Variscan deformation phases. Geol. Acta 2009, 7, 399-412. [CrossRef]

53. Scarrow, J.H.; Molina, J.F.; Bea, F.; Montero, P.; Vaughan, A.P.M. Lamprophyre dikes as tectonic markers of late orogenic transtension timing and kinematics: A case study from the Central Iberian Zone. Tectonics 2011, 30, TC4007. [CrossRef]

54. Arthaud, F.; Matte, P.H. Les décrochements tardi hercyniens du Sud-Ouest del'Europe. Géométrie et essai de reconstitution des conditions de la déformation. Tectonophysics 1975, 25, 139-171. [CrossRef]

55. Ribeiro, A.; Antunes, M.T.; Ferreira, M.P.; Rocha, R.B.; Soares, A.F.; Zbyszewski, G.; Almeida, F.M.; Carvalho, D.; Monteiro, J.H. Introdution à la géologie générale du Portugal; Mem Serv Geol Portugal: Lisbon, Portugal, 1979.

56. Pereira, E.; Ribeiro, A.; Meireles, C. Cisalhamentos hercínicos e controlo das mineralizações de Sn-W, Au e U na Zona Centro-Ibérica, em Portugal. Cuad. Lab. Xeolo Laxe 1993, 18, 89-119.

57. Marques, F.O.; Mateus, A.; Tassinari, C. The Late-Variscan fault network in central-northern Portugal (NW Iberia): A re-evaluation. Tectonophysics 2002, 359, 255-270. [CrossRef]

58. Ferreira, N.; Iglésias, M.; Noronha, F.; Pereira, E.; Ribeiro, A.; Ribeiro, M.L. Granitóides da Zona Centro Ibérica e seu enquadramento geodinêmico. In Geología de los Granitoides y Rocas Asociadas del Macizo Hesperico; Bea, F., Carnicero, A., Gonzalo, J., Lopez Plaza, M., Rodriguez Alonso, M., Eds.; Libro de Homenaje a L.C. García de Figuerola; Editorial Rueda: Madrid, Spain, 1987; pp. 37-51.

59. Dias, G.; Noronha, F.; Ferreira, N. Variscan plutonism in the Central Iberian zone (Northern Portugal). Eurogranites 2000. Field meeting, Guidebook.

60. Martins, H.C.B. Geoquímica e petrogénese de granitóides tarditectónicos e pós-tectónicos. Implicações metalogénicas. Ph.D. Thesis, University of Traás-os-Montes e Alto Douro, Vila Real, Portugal, 1998.

61. Neiva, A.M.R.; Williams, I.S.; Lima, S.M.; Teixeira, R. U-Pb and 39Ar/40Ar data constraining the ages of the source, emplacement and recrystallization/cooling events from late- to post- $\mathrm{D}_{3}$ Variscan granites of the Gouveia area, central Portugal. Lithos 2012, 153, 72-83. [CrossRef]

62. Sousa, M.B. Litostratigrafia e estrutura do "Complexo Xisto-Grauvaáquico ante-ordovícico"—Grupo do Douro (Nordeste de Portugal). Ph.D. Thesis, University of Coimbra, Coimbra, Portugal, 1982.

63. Sequeira, A.J.D. O Grupo das Beiras (Complexo Xisto-Grauvaáquico) entre Zebreira e Penamacor e a sua relação com o Ordovícico; Resumos do III Congresso Nacional de Geologia: Coimbra, Portugal, 1991.

64. Sequeira, A.J.D.; Sousa, M.B. O Grupo das Beiras (Complexo Xisto-Grauvaáquico) da região de Coimbra-Lousã. Memórias e Notícias. Publ. Mus. Lab. Mineral. Geol. Univ. Coimbra 1991, 112, 1-13.

65. Meireles, C.A.P.; Sequeira, A.J.S.; Castro, P.; Ferreira, N. New data on the lithostratigraphy of Beiras Group (Schist Greywacke Complex) in the region of Góis-Arganil-Pampilhosa da Serra (Central Portugal). Cuad Lab Xeolo Laxe 2013, 37, 105-124. 
66. Busink, R.W. Geochemistry of the Panasqueira Tungsten-Tin Deposit, Portugal. Ph.D. Thesis, University of Utrecht (Rijksuniversiteit Utrecht), Utrecht, The Netherlands, 1951.

67. Derré, C.; Lécolle, M. Contrôles structuraux de la mise en place des granites et des minéralisations de la zone de Fundão-Escarigo (Beira Baixa, Portugal). In IX Reunião sobre a Geologia do Oeste Peninsular; Pub Mus Lab Mineral e Geol, Fac Ciências do Porto: Porto, Portugal, 1985.

68. Portugal Ferreira, M.; Alves, E.I.; Regêncio Macedo, C.A. A zonalidade interna de um plutonito: Estruturas condicionantes e idades de evolução (plutonite do Fundão, Portugal Central). Mem. Not. Publ. Mus. Lab. Miner. Geol. Univ. Coimbra 1985, 99, 167-186.

69. Antunes, I.M.H.R.; Neiva, A.M.R.; Corfu, F. U-Pb Early Ordovician emplacement ages and K-Ar Variscan recrystallization ages of the Fundão granitic pluton, central Portugal. In Proceedings of the European Mineralogical Conference, Frankfurt, Germany, 24-28 September 2012; 2012; Volume 1. EMC2012-747.

70. Farinha Ramos, J. Mineralizações de metais raros de Seixo Amarelo-Gonçalo. Contribuição para o seu conhecimento. Ph.D. Thesis, University of Lisbon, Lisbon, Portugal, 1998.

71. Thadeu, D. Geologia do Couto Mineiro da Panasqueira. Com. Serv. Geol. Port. 1951, 32, 5-64.

72. Bloot, C.; Wolf, L.C. Geological features of the Panasqueira tin-tungsten ore- ocurrence (Portugal). Bol. Soc. Geol. Port. 1953, 11, 2-75.

73. Clark, A.H. Preliminary study of the temperatures and confining pressures of granite emplacement and mineralization, Panasqueira, Portugal. Trans. Inst. Min. Metall. 1964, 73, 813-824.

74. Conde, L.N.; Pereira, V.; Ribeiro, A.; Thadeu, D. Jazigos Hipogénicos de Estanho e volfrêmio. I Congresso Hispano-Luso-Americano de Geologia Económica. Direção Geral de Minas e Serviços Geológico. Lisboa 1971, 81.

75. Kelly, W.C.; Rye, R.O. Geologic, fluid inclusion, and stable isotope studies of the tin-tungsten deposits of Panasqueira, Portugal. Econ. Geol. 1979, 74, 1721-1822. [CrossRef]

76. Marignac, C. Geologic, fluid inclusions, and stable isotope studies of the Tin- Tungsten Deposits of Panasqueira, Portugal-A discussion. Econ. Geol. 1982, 77, 1263-1266. [CrossRef]

77. Neiva, A.M.R. Geochemistry of Greisenized Granites and Metasomatic Schist of Tungsten-Tin Deposits in Portugal. In Chemical Transport in Metasomatic Processes; Helgeson, H.C., Ed.; NATO ASI Series (Series C: Mathematical and Physical Sciences); Springer: Dordrecht, The Netherlands, 1987; Volume 218, pp. 681-699.

78. Snee, L.W.; Sutter, F.; Kelly, W.C. Thermochronology of economic mineral deposits: Dating the stages of mineralization at Panasqueira, Portugal by high-precision 40Ar/39Ar age-spectrum techniques on muscovite. Econ. Geol. 1988, 83, 335-354. [CrossRef]

79. Noronha, F.; Dória, A.; Dubessy, J.; Charoy, B. Characterization and timing of the different types of fuids present in the barren and ore-veins of the W-Sn deposit of Panasqueira, Central Portugal. Miner. Depos. 1992, 27, 72-79. [CrossRef]

80. Priem, H.N.A.; den Tex, E. Tracing crustal evolution in the NW Iberian Peninsula through Rb-Sr and U-Pb systematics of Paleozoic granitoids: A review. Phys. Earth Planet. Int. 1984, 35, 121-130. [CrossRef]

81. Ávila Martins, J.; Cândido de Medeiros, A.; Peres, A.M.; Teixeira, A.; Pilar, L.; Fernandes, A.P. Carta Geológica de Portugal na escala 1/50,000 da Folha 21-A (Sabugal). Serv. Geol. Port. 1964.

82. Teixeira, C.; Martins, J.A.; Cândido de Medeiros, A.; Mesquita, L.P.; Peres, A.M.; Pilar, L. Carta Geológica de Portugal na escala 1/50,000. Notícia explicativa da folha 21-A (Sabugal). Serv. Geol. Port. 1965, 25.

83. Neiva, A.M.R.; Ramos, J.M.F. Geochemistry of granitic aplite-pegmatite sills and petrogenetic links with granites, Guarda-Belmonte area, central Portugal. Eur. J. Miner. 2010, 22, 837-854. [CrossRef]

84. Antunes, I.M.H.R.; Neiva, A.M.R.; Silva, M.M.V.G.; Corfu, F. Geochemistry of S-type granitic rocks from the reversely zoned Castelo Branco pluton (central Portugal). Lithos 2008, 103, 445-465. [CrossRef]

85. Whitney, D.L.; Evans, B.W. Abbreviations for names of rock-forming minerals. Am. Miner. 2010, 95, $185-187$. [CrossRef]

86. Sistema de Informação de ocorrências e Recursos Minerais Portugueses (SIORMP). Available online: http://geoportal.lneg.pt/geoportal/egeo/bds/siorminp/ (accessed on 8 May 2020).

87. Jelinek, V. Characterization of the magnetic fabric of rocks. Tectonophysics 1981, 79, 63-67. [CrossRef]

88. Chadima, M.; Jelinek, V. Anisoft 4.2.-Anisotropy data browser. Contrib. Geophys. Geodesy 2009, 38, 41.

89. Bouchez, J.L.; Bernier, S.; Rochette, P.; Guineberteau, B. Log des susceptibilités magnétiques et anisotropies de susceptibilité dans le granite de Beauvoir: Conséquences pour sa mise em place. Géologie De La Fr. Brgm 1987, 2-3, 223-232. 
90. Nogueira, P.; Noronha, F. PLANIF: Um Programa de Anaálise de imagens para o Estudo de Microestruturas das rochas. IV Congresso Nacional de Geologia, Porto, 1995; Borges, F.S., Marques, M.M., Eds.; Mem Mus Labor Miner Geol Factory Ciênc University: Porto, Portugal, 1995; Volume 4, pp. 379-382.

91. Nogueira, P. Estudo de paleofluidos mineralizantes (Au, Ag, As) e sua migração. Aplicação a regiões auríferas do Norte de Portugal. Ph.D. Thesis, University of Porto, Porto, Portugal, 1997.

92. Simmons, G.; Richter, D. Microcracks in rock. In The Physics and Chemistry of Minerals and Rocks; Strens, R.G.J., Ed.; Wiley: New York, NY, USA, 1976; pp. 105-137.

93. Roedder, E. Fluid inclusion evidence on the genesis of ores in sedimentary and volcanic rocks. In Handbook of Stratabound and Stratiform Ore Deposits; Wolf, K.H., Ed.; Elsevier: Amsterdam, The Netherlands, 1976; Volume 2, pp. 67-110.

94. Roedder, E. Fluid inclusions. Rev. Miner. 1984, 12, 644.

95. Blenkinsop, T.G. Visualizing structural geology: From Excel to Google Earth. Comput Geosci. UK 2012, 45, 52-56. [CrossRef]

96. Allmendinger, R.W.; Cardozo, N.C.; Fisher, D. Structural Geology Algorithms: Vectors E Tensors; Cambridge University Press: Cambridge, UK, 2013.

97. Cardozo, N.; Allmendinger, R.W. Spherical projections with OSXStereonet. Comput. Geosci. 2013, 51, $193-205$. [CrossRef]

98. Paterson, S.R.; Ardill, K.; Vernon, R.; Zak, J. A review of mesoscopic magmatic structures and their potential for evaluating the hypersolidus evolution of intrusive complexes. J. Struct. Geol. 2019, 125, 134-147. [CrossRef]

99. Stipp, M.; Stünitz, H.; Heilbronner, R.; Schmid, S.M. The eastern Tonale fault zone: A 'natural laboratory' for crystal plastic deformation of quartz over a temperature range from 250 to $700{ }^{\circ} \mathrm{C}$. J. Struct. Geol. 2002, 24, 1861-1884. [CrossRef]

100. Tukerian, K.K.; Wedepohl, K.H. Distribution of the Elements in some major units of the Earth's Crust. Geol. Soc. Am. Bul. 1961, 72, 175-192.

101. Blatt, H.; Tracy, R.J.; Owens, B. Petrology: Igneous, Sedimentary, and Metamorphic, 3rd ed.; W.H. Freeman: New York, NY, USA, 1996.

102. Frost, B.R.; Barnes, C.G.; Collins, W.J.; Arculus, R.J.; Ellis, D.J.; Frost, C.D. A Geochemical Classification for Granitic Rocks. J. Petrol. 2001, 42, 2033-2048. [CrossRef]

103. Miyashiro, A. Volcanic rock series in island arcs and active continental margins. Am. J. Sci. 1970, 274, 321-355. [CrossRef]

104. Peacock, M.A. Classification of igneous rock series. J. Geol. 1931, 39, 54-67. [CrossRef]

105. Shand, S.J. The Eruptive Rocks, 2nd ed.; John Wiley: New York, NY, USA, 1943; p. 444.

106. De la Roche, H.; Leterrier, J.; Grandclaude, P.; Marchal, M. A classification of volcanic and plutonic rocks using R1,R2-diagrams and major element analysis-Its relationships with current nomenclature. Chem. Geol. 1980, 29, 183-210. [CrossRef]

107. Debon, F.; Le Fort, P. A cationic classification of common plutonic rocks and their magmatic associations: Principles, method, applications. Bull. Min. 1988, 111, 493-510. [CrossRef]

108. Batchelor, R.A.; Bowden, P. Petrogenetic interpretation of granitoid rock series using multicationic parameters. Chem. Geol. 1985, 48, 43-55. [CrossRef]

109. Evensen, N.M.; Hamilton, P.J.; O'Nions, R.K. Rare-earth abundances in chondritic meteorites. Geochim Cosmochim. Acta 1978, 42, 1199-1212. [CrossRef]

110. Wedepohl, K.H. The composition of the continental crust. Geochim. Cosmochim. Acta 1995, 59, 1217-1232. [CrossRef]

111. Shaw, D.M. A review of K-Rb fractionation trends by covariance analysis. Geochim. Cosmochim. Acta 1968, 32, 573-601. [CrossRef]

112. Ahrens, L.H.; Pinson, W.H.; Kearns, M. Association of rubidium and potassium and their abundance in common igneous rocks and meteorites. Geochim. Cosmochim. Acta 1952, 2, 229-242. [CrossRef]

113. El Bouseily, A.M.; El Sokkary, A.A. The relation between Rb, Ba and Sr in granitic rocks. Chem. Geol. 1975, 16, 207-219. [CrossRef]

114. Neiva, A.M.R.; Neiva, J.M.C.; Parry, S.J. Geochemistry of the granitic rocks and their minerals from Serra da Estrela, Central Portugal. Geochim. Cosmochim. Acta 1987, 51, 439-454. [CrossRef] 
115. Jelinek, V. Statistical processing of anisotropy of magnetic susceptibility measured on groups of specimens. Stud. Geophys. Geod. 1978, 22, 50-62. [CrossRef]

116. Hancock, P.L. Brittle microtectonics: Principles and practice. J. Struct. Geol. 1985, 7, 437-457. [CrossRef]

117. Anders, M.H.; Laubach, S.E.; Scholz, C.H. Microfractures: A review. J. Struct. Geol. 2014, 69, 377-394. [CrossRef]

118. Patiño Douce, A.E. What do experiments tell us about the relative contributions of crust and mantle to the origin of granitic magmas? Geol. Soc. Lond. Spec. Publ. 1999, 168, 55-75. [CrossRef]

119. Holtz, F.; Johannes, W. Genesis of peraluminous granites. I. Experimental investigation of melt compositions at 3 and $5 \mathrm{~kb}$ and various $\mathrm{H} 2 \mathrm{O}$ activities. J. Petrol. 1991, 32, 935-958. [CrossRef]

120. Patiño Douce, A.E.; Harris, N. Experimental constraints on Himalayan Anatexis. J. Petrol. 1998, 39, 689-710. [CrossRef]

121. Sant'Ovaia, H.; Martins, H.C.B.; Noronha, F. Oxidized and reduced Portuguese Variscan granites associated with W and Sn hydrothermal lode deposits: Magnetic susceptibility results. Comun. Geol. 2013, 100, 33-39, ISSN 0873-948X; e-ISSN 1647-581X.

122. Sant'Ovaia, H.; Olivier, P.; Ferreira, N.; Noronha, F.; Leblanc, D. Magmatic structures and kinematics emplacement of the Variscan granites from Central Portugal (Serra da Estrela and Castro Daire areas). J. Struct. Geol. 2010, 32, 1450-1465. [CrossRef]

123. Corry, C.E. Laccoliths; mechanics of emplacement and growth. Geol. Soc. Am. Spec. Pap. 1988, 220, 1-110. [CrossRef]

124. Clemens, J.D.; Mawer, C.K. Granitic magma transport by fracture propagation. Tectonophysics 1992, 204, 339-360. [CrossRef]

125. Paterson, S.R.; Fowler, T.K. Re-examination pluton emplacement processes. J. Struct. Geol. 1993, 15, $191-206$. [CrossRef]

126. Romaán-Berdiel, T.; Brun, J.P.; Gapais, D. Analogue models of laccolith formation. J. Struct. Geol. 1995, 17, 1337-1346. [CrossRef]

127. Román-Berdiel, T.; Gaspais, D.; Brun, J.P. Granite intrusion along strike-slip zones in experiment and nature. Am. J. Sci. 1997, 297, 651-678. [CrossRef]

128. Román-Berdiel, T. Geometry of granite emplacement in the upper crust: Contributions of analogue modelling. In Understanding Granites: Integrating New and Classical Techniques; Castro, A., Fernández, C., Vigneresse, J.L., Eds.; Geological Society of London: London, UK, 1999; Volume 168, p. 77. [CrossRef]

129. Petford, N.; Cruden, A.R.; McCaffrey, J.W.; Vigneresse, J.L. Granite magma formation, transport and emplacement in the Earth's crust. Nature 2000, 408, 669-673. [CrossRef] [PubMed]

130. Castro, A. Structural pattern and ascent model in the Central Extremadura batholith, Hercynian belt, Spain. J. Struct. Geol. 1986, 8, 633-645. [CrossRef]

131. Hutton, D.H.W.; Dempster, T.J.; Brown, P.E.; Becker, S.D. A new mechanism of granite emplacement: Intrusion in active extensional shear zones. Nature 1990, 343, 452-455. [CrossRef]

132. Vigneresse, J.L.; Clemens, J.F. Granitic magma ascent and emplacement: Neither dispirism nor neutral buoyancy. In Salt, Shale and Igneous Diapirsin and around Europe; Venderville, B., Mart, Y., Vigneresse, J.L., Eds.; Geological Society of London: London, UK, 2000; Volume 174, pp. 1-19.

133. Lehmann, B. Metallogeny of Tin; Lecture Notes in Earth Sciences; Springer: Berlin, Germany, 1990.

134. Activation Laboratories Lda. Official Page. Available online: https:/actlabs.com/geochemistry/ lithogeochemistry-and-whole-rock-analysis/lithogeochemistry/ (accessed on 13 January 2020).

(C) 2020 by the authors. Licensee MDPI, Basel, Switzerland. This article is an open access article distributed under the terms and conditions of the Creative Commons Attribution (CC BY) license (http://creativecommons.org/licenses/by/4.0/). 